\section{НОВАЯ НАУКА}

Международный центр научного партнерства
NEW SCIENCE International Center for Scientific Partnership

\title{
РАЗВИТИЕ НАУКИ В ЭПОХУ ЦИФРОВИЗАЦИИ: ПРОБЛЕМЫ, ТЕНДЕНЦИИ, ПРОГНОЗЫ
}

\author{
Монография
}

г. Петрозаводск

Российская Федерация

МЦНП «Новая наука»

2021 
УДК 001.12

ББК 70

P17

Рекомендовано к публикаџии редакиионной коллегией МЦНП «Новая наука»

\section{Рецензенты:}

Ершова Л.В.

доктор педагогических наук, профессор

ФГБОУ ВО «Ивановский государственный университет»

Андрианова Л.П.

доктор технических наук, профессор

ФГБОУ ВО «Уфимский государственный нефтяной технический университет»

\section{Коллектив авторов}

Андреев Н.А., Ахтариева Р.Ф., Батов А.А., Беляков Б.Л., Бушмелева Г.В., Василенко И.В., Василенко И.В., Везиров Т.Г., Денисов К.М., Дмитриева Т.В., Кирьянова Г.Г., Козаева Г.Р.,

Лобанова Е.И., Рахманова А.Р., Салимуллина Е.В., Шапирова Р.Р., Шинкевич В.Е.

РАЗВИТИЕ НАУКИ В ЭПОХУ ЦИФРОВИЗАЦИИ: ПРОБЛЕМЫ, ТЕНДЕНЦИИ, ПРОГНОЗЫ : [монография / Андреев Н. А. и др.] ; Петрозаводск : МЦНП «Новая наука», 2021. — 105 с. : ил. — Коллектив авторов.

ISBN 978-5-00174-199-2

В монографии рассматривается круг актуальных вопросов, стоящих перед современными исследователями в обозначенных областях, обозначается комплекс научной проблематики охватываемых сфер, предлагается новое видение ряда концептов. Издание может быть полезно научным работникам, специалистам-практикам, преподавателям всех уровней образования, интересующимся проблемами развития современной науки.

Авторы публикуемых материалов несут ответственность за содержание своих работ, точность цитат, легитимность использования иллюстраций, приведенных цифр, фактов, названий, персональных данных и иной информации, а также за соблюдение законодательства Российской Федерации и сам факт публикации.

Полные тексты статей в открытом доступе размещены в Научной электронной библиотеке Elibrary.ru в соответствии с Договором № 467-03/2018K от 19.03.2018 г.

УДК 001.12

ББК 70

ISBN 978-5-00174-199-2

(C) Коллектив авторов, текст, иллюстрации, 2021

(с) МЦНП «Новая наука» (ИП Ивановская И.И.), оформление, 2021 


\section{ОГЛАВЛЕНИЕ}

ГЛАВА І. ЦИФРОВИЗАЦИЯ КАК ОБЩЕСТВЕННОЕ ЯВЛЕНИЕ, ПРЕДМЕТ ФИЛОСОФСКОГО АНАЛИЗА И ЕЕ ВЛИЯНИЕ НА СИСТЕМУ ВЫСШЕГО ПРОФЕССИОНАЛЬНОГО ОБРАЗОВАНИЯ И ИССЛЕДОВАНИЯ

В ОБЛАСТИ СОЦИАЛЬНЫХ НАУК 4

Беляков Борис Львович, Шинкевич Владимир Ефимович, Андреев Никита Андреевич, Дмитриева Татьяна Викторовна

ГЛАВА ІІ. СОЦИАЛЬНО-ЦИФРОВЫЕ ПРАКТИКИ РОССИЙСКОЙ МОЛОДЕЖИ И ДИСТАНТНАЯ РАБОТА В УСЛОВИЯХ ПАНДЕМИИ КОРОНАВИРУСА 22

Василенко Инна Викторовна, Василенко Илья Викторович

ГЛАВА ІІІ. ПРАКТИКА ПРОФЕССИОНАЛЬНОЙ ПОДГОТОВКИ

МАГИСТРОВ ПЕДАГОГИЧЕСКОГО ОБРАЗОВАНИЯ

ПРИ ФГБОУ ВО «ДАГЕСТАНСКИЙ ГОСУДАРСТВЕННЫЙ

ПЕДАГОГИЧЕСКИЙ УНИВЕРСИТЕТ» И СПЕЦИАЛИСТОВ

ПРИ ГАОУ ВПО «ЮГО-ОСЕТИНСКИЙ ГОСУДАРСТВЕННЫЙ

УНИВЕРСИТЕТ ИМЕНИ А.А.ТИБИЛОВА» В УСЛОВИЯХ

ЦИФРОВИЗАЦИИ ОБРАЗОВАНИЯ 38

Везиров Тимур Гаджиевич, Козаева Гульнара Ролландовна

ГЛАВА IV. МОТИВАЦИЯ ПРОФЕССИОНАЛЬНОГО СТАНОВЛЕНИЯ БУДУЩЕГО УЧИТЕЛЯ В УСЛОВИЯХ ПРИМЕНЕНИЯ

ДИСТАНЦИОННЫХ ТЕХНОЛОГИЙ 55

Рахманова Алсу Рамилевна, Ахтариева Разия Файзиевна,

Салимуллина Елена Викторовна, Шапирова Раиля Равильевна

ГЛАВА V. ОСНОВНЫЕ НАПРАВЛЕНИЯ РАЗВИТИЯ КОГНИТИВНОЙ ЛИНГВИСТИКИ (НА МАТЕРИАЛЕ МОНОГРАФИИ ВИВИАНА ЭВАНСА «COGNITIVE LINGUISTICS. A COMPLETE GUIDE» SECOND EDITION. EDINBURGH: EDINBURGH UNIVERSITY PRESS, 2019. - 858 P.)

К.М. Денисов, Е.И. Лобанова

ГЛАВА VІ. СТАТИСТИЧЕСКИЕ МЕТОДЫ

В НОРМИРОВАНИИ ЧИСЛЕННОСТИ ПЕРСОНАЛА .79

Кирьянова Галина Геннадьевна

ГЛАВА VII. ЦИФРОВИЗАЦИЯ ПРЕДПРИЯТИЙ

ОБОРОННО-ПРОМЫШЛЕННОГО КОМПЛЕКСА

Батов Андрей Александрович, Бушмелева Галина Владимировна 


\section{ГЛАВА I.}

УДК 304.9

\section{ЦИФРОВИЗАЦИЯ КАК ОБЩЕСТВЕННОЕ ЯВЛЕНИЕ, ПРЕДМЕТ ФИЛОСОФСКОГО АНАЛИЗА И ЕЕ ВЛИЯНИЕ НА СИСТЕМУ ВЫСШЕГО ПРОФЕССИОНАЛЬНОГО ОБРАЗОВАНИЯ И ИССЛЕДОВАНИЯ В ОБЛАСТИ СОЦИАЛЬНЫХ НАУК}

Беляков Борис Львович д.ф.н., профессор

Шинкевич Владимир Ефимович д.соц.н., доцент

\section{Андреев Никита Андреевич Дмитриева Татьяна Викторовна}

Аннотация: Эпоха информационной революции, начавшаяся во второй половине XX века с появлением первого компьютера, продолжается в третьем десятилетии нынешнего столетия на её цифровом этапе, связанном с цифровизацией. Следствием последней стали кардинальные изменения во всех сферах общественной жизни (материально-экономической, духовной, социальной, политической), что в свою очередь вызвало противоречие между возможностью доступа к огромным информационным ресурсам и реальностью их использования в образовательном процессе высшей профессиональной школы, научных исследованиях обществоведов. Данные изменения чреваты увеличением разрыва между реальной и виртуальной действительностью, угрозой деградации естественного и профессионального интеллекта.

Ключевые слова: информационная революция (эволюция), цифровизация, интернет, цифровая экономика, образовательный процесс, высшее профессиональное образование, наука, военная акмеология и кибернетика. 


\title{
DIGITALIZATION AS A SOCIAL PHENOMENON, THE SUBJECT OF SOCIO-PHILOSOPHICAL ANALYSIS AND ITS IMPACT ON THE SYSTEM OF PROFESSIONAL EDUCATION AND SCIENTIFIC RESEARCH IN THE FIELD OF HUMANITIES
}

\author{
Belyakov Boris Lvovich \\ Shinkevich Vladimir Efimovich \\ Andreev Nikita Andreevich \\ Dmitrieva Tatyana Viktorovna
}

\begin{abstract}
The era of the information revolution, which began in the second half of the XX century with the advent of the first computer, continues in the third decade of this century at its digital stage, associated with digitalization. The latter resulted in drastic changes in all spheres of public life (material-economic, spiritual, social, political), which in turn caused a contradiction between the possibility of access to huge information resources and the reality of their use in the educational process of higher professional schools, scientific research of social scientists. These changes are fraught with an increase in the gap between real and virtual reality, the threat of degradation of natural and professional intelligence.
\end{abstract}

Key words: information revolution (evolution), digitalization, Internet, digital economy, educational process, higher professional education, science, military acmeology and cybernetics.

Вторую половину XX - первые десятилетия XXI веков принято считать «эрой информационной революции» (нам ближе понятие «эволюция» - Б.Б., В.Ш), которая началась с появлением первых компьютеров и ознаменовала переход общества к использованию принципиально новых средств связи, передачи разнородных данных, качественно иному уровню развития труда, процессам информационного взаимодействия. На первом этапе информационной революции (т.н. «времени информатики», начала информатизации) информация стала стратегическим ресурсом общества, её производство и потребление составили основу эффективного функционирования и развития абсолютного большинства областей общественной жизни. «Информатика» прочно завоевало свое место в образовательном процессе различных уровней получения знаний, проникла во 


\section{РАЗВИТИЕ НАУКИ В ЭПОХУ ЦИФРОВИЗАЦИИ: ПРОБЛЕМЫ, ТЕНДЕНЦИИ, ПРОГНОЗЫ}

все сферы экономического производства, в общественную и личную жизнь граждан. Право на информацию и доступ к ней признаны жизненной ценностью для всех членов социума. Не подвергая сомнению позитивный, прорывной ее научный и технический характер, мы не заметили, как изменился окружающий мир и сознание живущих в нем граждан. В лексиконе речи каждого современного человека закрепились иностранные слова (а не понятия: браузер, юзер, провайдер, сеть, «лузер», поставщик услуг, социальные сети, скайп, гаджеты (читай: гад же ты-?), а вчера читавший книгу, газету, ходивший в кино, театр, стадион...человек уткнулся в свой «айфон», «айпад», планшет... скачивает «модный продукт», находит истину в «Википедиях», интернетмагазинах, без особого труда присваивает чужие наработки, выдавая их за свой интеллектуальный капитал, порождая узаконенный плагиат. За 2020-2021 годы «Covid-изоляционный период» породил помимо инфекционных, медицинских целый комплекс общественно-информационных проблем, требующих осмысления и разрешения. Авторы этих строк всерьез задумались над новизной и актуальностью научной задачи с позиции социально-философского подхода и стремятся раскрыть феномен «цифровизации» как тренд и явление российской действительности, его влияние на развитие социально-гуманитарной науки, образовательный процесс в высшей школе РФ (на примере МГОУ), ее силовых структурах (в частности, ВА РВСН - г. Балашиха, Сиб.ЮИ МВД РФ и Академии СКР - Санкт- Петербург) как предметных областях своих исследований, в процессе подготовки, написания и защиты диссертаций. Первые научные результаты нашли свое отражение в авторских работах [1].

Понимая под «информатизацией» процесс формирования и использования информационных ресурсов, в ходе которого люди получают возможность ускорить процессы взаимодействия с помощью компьютеров, гаджетов, различных программ и технологий, мы констатируем, что в настоящее время уже сформирована новая отрасль - информационная индустрия, связанная с производством технических средств, методов, технологий для производства новых знаний, «венцом» которой является интернет, позволяющий вести информационный обмен в глобальном масштабе. Третье десятилетие XXI века вполне уместно и уже без оговорок можно назвать временем цифрового этапа информационной революции (эволюции-?), связанным с развитием трансграничных, глобальных, информационнотелекоммуникационных сетей, охватывающих все страны и континенты, 


\section{РАЗВИТИЕ НАУКИ В ЭПОХУ ЦИФРОВИЗАЦИИ: ПРОБЛЕМЫ, ТЕНДЕНЦИИ, ПРОГНОЗЫ}

проникающих в каждый дом и воздействующих на большие общности людей в целом и человека в отдельности. К сожалению, в российском научном обществознании нет единого, устоявшегося подхода к анализу данного феномена [2, с.6-7], как и Концепции цифровизации российского информационного общества, управленческого сегмента, понятной системы информационной безопасности от внешних и внутренних угроз, видения и разрешения злободневных информационных проблем современности. Существующая нормативно - правовая теоретическая база в РФ вызывает иногда непонимание и недоверие [3].

Термин «цифровизация» как понятие и научная категория используется как в узком, так и в широком смысле. В узком он понимается как выражение информации в цифровой форме. В широком - как переход к цифровой форме отражения бытия всех сфер нашей жизни (материально-экономической, социальной, духовной, политической), как форма отражения окружающего нас объективного мира. Нам представляется, что цифровизация является одной из характерный сторон современного «потребительского» мира и созданного им «общества», обостряющего социальные противоречия между различными слоями населения, государствами и их коалициями (Европа-Америка-КитайРоссия и т.н. «информационно отсталыми странами»). В этой связи в России остро обозначилась в последние два десятилетия и крайне слабая общефилософская подготовка выпускников ВУЗов РФ, аспирантов и докторантов ввиду выхолащивания курсов еe преподавания, смены образовательных стандартов и, как следствие, тематических планов и учебных программ, (каждые пять-шесть лет), коммерциализации самой идеологии высшей школы, реформирование (читай - сокращение и уничтожение диссертационных советов, национальных, республиканских, территориальных (областных) философских школ, связанных с именами выдающихся философов прошлого, перевод самой системы образования в сферу услуг, бизнеса и коррупции, всей гуманитарной составляющей сознания выпускников [4, с.116117], что находит свое выражение в качестве конечного продукта российского научного обществознания. Как это не парадоксально, в абсолютном большинстве ВУЗов (кроме философских, юридических и медицинских специальностей) во всех военных академиях, университетах, институтах и училищах программами не предусмотрено изучение ни профессиональной, ни формальной логики, позволяющей заложить основу методологии 


\section{РАЗВИТИЕ НАУКИ В ЭПОХУ ЦИФРОВИЗАЦИИ: ПРОБЛЕМЫ, ТЕНДЕНЦИИ, ПРОГНОЗЫ}

мыслительной деятельности, весь курс «любви к мудрости» укладывается в несколько дидактических единиц на первом либо втором годах обучения. Уровень и квалификация большинства самих преподавателей не отвечает профилю будущей профессиональной деятельности выпускников с отсутствием реального профессионального опыта в указанных сферах [5, с. 11-14]

Безусловным плюсом «цифровизации» является тенденция «ускорения» темпа и ритма жизни. В быту она освобождает многих (у кого есть деньги-?) от повседневных забот (онлайн-шопинг, офлайн-доставка, онлайн-заказ такси и т.д.). Люди получают больше свободы и возможностей для реализации свих потребностей и интересов.

Однако, здесь проявляется настораживающая закономерность, когда естественное стремление человека, сформированного потребительским обществом, получить все и сразу ..., приводит к нервным срывам и депрессиям, если это не получается по «щучьему велению-моему хотению». Ведь в век цифровых технологий мы ориентируемся на телевизионные клипы о жизни других людей, то есть у нас целенаправленно формируют определенные стереотипы мышления и поведения. Их несоответствие с реальностью влечёт появление различных комплексов и неудовлетворенности собственной жизнью. Современный цивилизованный человек становится заложником сверхтемпа, перестает контролировать свои чувства. Более того, люди отвыкают ставить перед собой долговременные цели, над достижением которых нужно трудиться и добиваться. Сегодня почти все, что нас окружает, связано между собой и интернетом. Понятие «интернет вещей» подразумевает внедрение технологий, объединяющих вокруг одной облачной платформы все устройства, используемые нами в быту: телефон, электронную почту, электрические бытовые приборы и др. Социальные сети все больше заменяют личностное общение, даже родителей с детьми. Данная тенденция отрицательно сказывается на личностных коммуникативных способностях личностигражданина-профессионала. Потеря навыка межличностного общения набирает обороты. В период планетарной борьбы с Covid - 19 проблемы из реальной жизни человека (в которой он существует, особенно для молодого поколения) перемещаются в мир виртуальный, где в компьютерных играх, сетевом виртуальном общении, проживая «несколько жизней», человек утрачивает связь с реальною действительность и медленно сходит с ума в образе «героя, супермена и творца» [1, Дмитриева Т.В., с. 66]. 


\section{РАЗВИТИЕ НАУКИ В ЭПОХУ ЦИФРОВИЗАЦИИ: ПРОБЛЕМЫ, ТЕНДЕНЦИИ, ПРОГНОЗЫ}

Профессор Шерри Тёрки из Массачусетского технологического института утверждает: «Мы изобрели и совершенствовали технологии, которые, в конечном итоге, обворовали нас» [6]. Глобальность данной проблемы ныне осознана на теоретическом и эмпирическом уровнях. Все чаще накладывается запрет на использование мобильных телефонов в школах, все больше родителей проникается важностью живого общения со своими детьми. Появляется больше мест для простого личностного общения: интеллектуальные кафе, игровые клубы, возвращается мода на домашние настольные игры.

Из этого следует, что социальная сфера жизнедеятельности человека претерпела качественные преобразования под давлением процесса цифровизации. Не все изменения благоприятно сказываются на нашей жизни. Однако, радует наличие осознания у людей важности грядущих изменений и желания уменьшить их негативные последствия. Процесс цифровизации привел к серьезным изменениям в материально-экономической сфере жизни общества. Появилось целое направление «цифровая экономика» - система экономических, социальных и культурных отношений, основанных на использовании цифровых информационно-коммуникационных технологий, где данные в цифровой форме выступают ключевым фактором производства во всех сферах социальноэкономической деятельности, повышающим конкурентоспособность страны, качество жизни граждан, обеспечивающим экономический рост и национальный суверенитет [7, с.6-7].

Цифровая экономика ныне представлена на трех уровнях, влияющих на жизнь общества, в тесном взаимодействии: сферы деятельности, где осуществляется взаимодействие конкретных субъектов (поставщиков и потребителей товаров и услуг); платформы и технологии, где формируются компетенции для развития рынков и отраслей экономики; среда, которая создает условия для развития платформ, технологий и эффективного взаимодействия субъектов рынков [8]. Целью цифровой экономики, является повышение эффективности всех процессов, в первую очередь, за счет применения новых технологий переработки данных и передачи информации, новых методов принятия решений, основанных на цифровой трансформации информации. Следствием цифровизации можно считать сформировавшийся тренд на совместное потребление, получивший воплощение в явлении шерингэкономики (от англ. Sharing economy-экономика совместного потребления), основой которой является не обладание благами, а возможность их использования. 


\section{РАЗВИТИЕ НАУКИ В ЭПОХУ ЦИФРОВИЗАЦИИ: ПРОБЛЕМЫ, ТЕНДЕНЦИИ, ПРОГНОЗЫ}

На основании этих фактов можно сделать вывод о том, что в современном технологичном мире всякие привязанности и обязательства традиционного общества, вызываемые, в том числе, правом частной собственности, не существенны, что способствует формированию космополита, человека, «не помнящего родства», а значит и Родины, что является одной из целей глобального потребительского общества, но и угрозой национальной безопасности России.

Оставляя за кадром данной работы влияние информатизации на основные сферы жизни современной РФ (экономическую, политическую, социальную, духовную и собственно военную), что является предметной областью научных интересов соискателей (А.Н. и Д.Т.), мы хотим осмыслить связь и проблемы современного высшего профессионально образования и перспективы нашей науки, ее социально-гуманитарной составляющей. Считаем примером наиболее удачного разрешения существующего противоречия положительный опыт уникального подразделения ( кафедры 1.ОАК) Военной академии РВСН имени Петра Великого, которая по итогам 2020 учебного года признана лучшим политехническим ВУЗом ВС РФ и награждена Указом Президента страны орденом Жукова в честь двухвекового юбилея и выдающиеся заслуги в доле подготовки офицерских кадров «ядерного щита нашей Родины - Ракетных войск стратегического назначения»[9]. Кафедра №1 ОАК - «Военной акмеологии и кибернетики» в августе 2021 года будет праздновать свое 45-летие $[10$, с. 16-17]. Являясь общеакадемической, это практически автономный научно-технологический центр прикладной военно-инженерной педагогики, решающий дидактические, воспитательные и научно-прикладные задачи в соответствии с предназначением РВСН, подчиняясь заместителю начальника академии по учебной и научной работе. Помимо образовательного процесса в академии кафедра решает стратегические научно-исследовательские задачи оборонных ведомств страны. Практически с момента образования в 1976 году как «Кафедра педагогики, психологии и методики интенсивного обучения» ей в подчинение была сформирована и придана научноисследовательская лаборатория «Теории и практики прогнозирования военного образования» (НИЛ-17) [11, с.14-15].

В разные годы кафедрой руководили: полковник-инженер Золотарев Александр Александрович (1976-1982) - ктн., проф.; Фокин Юрий Григорьевич (1982-1985) - дтн., проф.; Ванюрихин Геннадий Иванович (1986-1991) - дтн., 


\section{РАЗВИТИЕ НАУКИ В ЭПОХУ ЦИФРОВИЗАЦИИ: ПРОБЛЕМЫ, ТЕНДЕНЦИИ, ПРОГНОЗЫ}

проф.,; Мачулин Василий Васильевич (1991-1993) - дтн., проф.,; Сергеев Константин Григорьевич (1993-1997) - ктн., доц.,; Рюмин Валерий Павлович (1997-2003) - ктн., доц.,; Пальмов Владимир Геннадьевич (2003 - 2012) - кпн., проф. Фасоля Алексей Анатольевич (2012-2019) - дпн.,проф. Именно эти руководители обеспечили разработку, создание и внедрение передовых информационных технологий не только в образовательный процесс академии, но и технологическое и информационное сопровождение, компьютерную грамотность боевых расчетов пуска дежурных смен боевого управления всех звеньев РВСН. За комплекс научно-исследовательских и опытноконструкторских работ по проблемам целеполагания, педагогических технологий подготовки военных специалистов для РВСН, иных силовых структур, методов, средств и форм обучения, диагностики и коррекции состояния обучаемых, а также за создание новой учебно-научной и материальной базы решением Военно-промышленной комиссии Совета Министров СССР в 1982 году коллективу кафедры была присуждена специальная премия. С 1986 года кафедра получила новое наименованиекафедра «Военной кибернетики», что обусловило прикладную задачу по педагогическому сопровождению подготовки специалистов к эксплуатации принципиально новой техники и вооружения в РВСН. В круг дидактических задач коллектива вошли проблемы исследований и разработки компьютерных технологий подготовки офицерского состава Стратегических ядерных сил, инженерных и руководящих кадров оборонных отраслей промышленности. В 1988 г. была начата и успешно завершена Программа комплексного применения средств ЭВТ и тренажных систем в подготовке военных специалистов для $\mathrm{PBCH}$, а также решались специальные задачи, связанные с началом с 1993 г. всестороннего реформирования ВС РФ. В последующие годы коллектив кафедры занимался решением педагогических проблем организации подготовки преподавателей негуманитарных дисциплин для высшей и средней военных школ на базе передовых информационных технологий. С 2003 г. на базе кафедры успешно выполняются задачи по формированию и реализации программ послевузовского образования (адъюнктуры), образовательных программ профессиональной подготовки военнослужащих к новому для них виду деятельности (педагогической), получения дополнительной квалификации «Преподаватель высшей школы», а также программ повышения квалификации преподавателей. $\mathrm{B}$ условиях непрерывного реформирования (читай- 


\section{РАЗВИТИЕ НАУКИ В ЭПОХУ ЦИФРОВИЗАЦИИ: ПРОБЛЕМЫ, ТЕНДЕНЦИИ, ПРОГНОЗЫ}

сокращения) важно было не только выжить, но и сохранить научнопедагогический потенциал, десятилетиями наработанные связи и отношения с ведущими педагогическими школами страны, обеспечить преемственность поколений педагогов, подготовить свой молодой резерв. С августа 2012 по сентябрь 2019 года кафедру военной акмеологии и кибернетики возглавлял полковник Фасоля А.А., пришедший докторантом, 28-летним майором, ктн., а завершившим военную службу в 40 лет полковником, доктором пед. наук, профессором. С сентября 2019 года по настоящее время начальником кафедры является полковник Смирнов Евгений Валерьевич, кандидат философских наук, доцент. Имея в составе научной школы 16 докторов наук и 22 кандидата наук, кафедра до 2019 года решала широкий спектр задач: реализация образовательных программ высшего образования; подготовка и апробация дополнительных профессиональных программ - программ повышения квалификации, программ профессиональной переподготовки руководящего, профессорско-преподавательского и научного состава вузов Министерства обороны; организация и проведение на высоком научном уровне учебной и методической работы по учебным дисциплинам кафедры; проведение воспитательной работы со слушателями; выполнение фундаментальных и (или) прикладных научных исследований, направленных на укрепления обороноспособности и безопасности страны; подготовка научнопедагогических и научных кадров по профилю кафедры, что невозможно было бы осуществить без достижений цифровизации и компьютеризации всех звеньев единой научно-педагогической цепи. Образовательные программы включали в себя: основная образовательная программа высшего образования - подготовка кадров высшей квалификации; дополнительные профессиональные программы - программы профессиональной переподготовки военнослужащих: для выполнения нового вида профессиональной деятельности в сфере педагогики высшей школы; для получения дополнительной квалификации «Преподаватель высшей школы»; профессиональная переподготовка военнослужащих по одной из гражданских специальностей: Менеджер в сфере высшего профессионального образования; Педагогика высшей школы; дополнительные профессиональные программы - программы повышения квалификации: начальников вузов (филиалов вузов) MO, их заместителей (помощников, кроме помощников по МТО), начальников факультетов вузов (филиалов вузов) МО; 


\section{РАЗВИТИЕ НАУКИ В ЭПОХУ ЦИФРОВИЗАЦИИ: ПРОБЛЕМЫ, ТЕНДЕНЦИИ, ПРОГНОЗЫ}

преподавательского состава вузов МО, учебных военных центров и военных кафедр при гражданских вузах по применению инновационных педагогических технологий; преподавательского состава вузов МО, учебных военных центров и военных кафедр при гражданских вузах по управлению качеством образовательного процесса; преподавательского состава вузов МО, учебных военных центров и военных кафедр при гражданских вузах по развитию коммуникативной культуры. В настоящее время коллектив научной школы кафедры продолжает исследования в следующих приоритетных научных направлениях: организационно-управленческое - совершенствование системы военного образования, долгосрочное прогнозирование и моделирование развития системы образования на основе теории самоорганизации, совершенствование системы управления интегрированными научнообразовательными структурами и информационно-методическое обеспечение их деятельности: разработаны современная концепция теории и методология процессов самоорганизации при подготовке военных специалистов, эксплуатирующих современные высокотехнологические системы вооружения; обоснованы и научно доказаны в докторских диссертациях (11 - с 2010 по 2020 г.) закономерности развития педагогической системы дополнительного профессионального образования преподавательского состава военных вузов; представлена как целесообразная и эффективная модель создания интегрированных научно-образовательных структур в Вооружённых силах РФ; обоснованы принципы организации интегрированных научно-образовательных структур на основе анализа современных подходов в теории управления социальными системами, методологии моделирования сложных самоорганизующихся процессов применительно к интеграции науки и образования; разработаны механизмы использования ресурсов интегрированных объединений вузов и научных структур для повышения эффективности управления содержанием образовательных программ подготовки военных кадров и развития инновационной деятельности в интересах обороноспособности страны; предложена и обоснована система критериев и условий обеспечения устойчивого развития интегрированных научно-образовательных структур в Вооруженных силах РФ; разработаны и представлены в виде методик, методических рекомендаций предложения по совершенствованию нормативно-правового и методического обеспечения деятельности научно-образовательного центра Вооруженных сил РФ; 


\section{РАЗВИТИЕ НАУКИ В ЭПОХУ ЦИФРОВИЗАЦИИ: ПРОБЛЕМЫ, ТЕНДЕНЦИИ, ПРОГНОЗЫ}

предложения и рекомендации по разработке документов, регламентирующих деятельность научно-образовательного центра Вооруженных сил РФ; обоснованы и апробированы в ходе педагогических экспериментов поправки в принципах, социально-педагогические условиях, функции и технологии организационно-педагогического обеспечения управления военным образованием; разработаны теоретические основания, цели, задачи государственного заказа подготовки военных специалистов, в том числе преподавателей вузов МО РФ, акмеолого-педагогическое (дидактическое) совершенствование системы профессионального становления военных специалистов, эксплуатирующих современные высокотехнологические системы вооружения, повышение качества военного образования, основанного на формировании компетенций; обоснована структура и содержание ДПО на базе высшего профессионального образования для преподавательского состава военно-технических вузов; разработана и внедрена модель системы профессионального развития и переподготовки преподавательского состава вузов МО РФ; предложен и внедрен в практику алгоритм формирования должностного функционала персонала органов военного управления для всех уровней иерархической управляющей системы MO РФ; выработаны инновационные подходы к объему и содержанию подготовки военных педагогических кадров; разработана концепция развития адаптивного потенциала военнослужащих; всесторонне обоснован отбор содержания образования, принципы и технологии формирования квалификационных требований к минимуму содержания и уровню подготовки учебных планов и программ преподавательского состава военно-технических вузов для получения дополнительной квалификации «Преподаватель высшей школы», которые успешно внедрены в учебный процесс Военной академии РВСН имени Петра Великого, Военного университета, Академии ФСБ России, Пограничной академии ФСБ России; системно и комплексно исследованы проблемы сущности, основных подходов, стратегии, технологии педагогической деятельности на современном этапе. разработаны закономерности, принципы, модели и технологии реализации индивидуализации обучения научнопедагогических и педагогических кадров в вузах Министерства обороны России; обоснованы подходы к совершенствованию педагогических подсистем образовательной системы РВСН, всестороннего обеспечения их целостности и согласованности. Еще совсем недавно в высшую школу РВСН входили 


\section{РАЗВИТИЕ НАУКИ В ЭПОХУ ЦИФРОВИЗАЦИИ: ПРОБЛЕМЫ, ТЕНДЕНЦИИ, ПРОГНОЗЫ}

подразделения 11 высших военно-учебных заведений (2 академии,9 военных институтов). Сегодня это лишь ВА PBCH (г. Балашиха) и ее филиал в г. Серпухов...К сожалению, в 2021 году после очередного реформирования, «оптимизации» организационно-штатных структур всех ВУЗов МО от былого величия осталось совсем не много. Пока система держится на «старой гвардии советской военной высшей школы», a ee молодые представители, едва достигнув докторских и профессорских вершин, покидают не только «альмаматер», их вскормившую, но и офицерскую службу как таковую...

И хотя за последние 5 лет в условиях автономности «научная гуманитарная школа РВСН» пополнилась 3 докторами, 5 профессорами ,5 доцентами и 16 кандидатами педагогических наук, не было защищено ни одной работы по философии, социологии, политологии, праву, экономике, культурологии и иным социальным направлениям. Вся система подготовки НПК для силовых структур сегодня никакой критики не заслуживает и нуждается в «обнулении и перезагрузке». Представляется, что и с подобным научным потенциалом, опытом работы, традициями и обычаями были все основания с оптимизмом смотреть в будущее. Вместе с тем, жизнь не стоит на месте, a порождает новые проблемы, требующие не только глубокого осмысления, но и мудрого управленческого решения. ПОНЯТЬ ПРОБЛЕМУ это наполовину ее решить! В новых условиях это относится к вопросам философии педагогики и управлению военным образованием. С введением в действие ФЗ РФ «Об образовании» с 1 сентября 2013 года и приказа МО РФ № 670 кардинальных изменений в лучшую сторону не произошло. Более того, забвение принципов «непрерывности и преемственности», копирование «западной модели бакалавров-магистров» для ВВШ породили ряд дополнительных противоречий. Сегодня лишь просматриваются контуры новой военной акмеологии и системы гуманитарной составляющей профессионального образования офицера, над которой, однако, предстоит еще много работать [2. с 48-53]. Эти проблемы в полом объеме относительно гуманитарной компоненты присущи МВД, СКР, иным ведомствам «силовых структур» РФ, в следствие чего и решать их необходимо СОВМЕСТНО! Военное образование и ее педагогическая составляющая - специфическая область деятельности по подготовке кадров, которые должны обладать уникальными свойствами и качествами, быть способными не только жертвовать собой, но и в необходимых случаях посылать других на выполнение смертельно опасных заданий ради интересов обороны и безопасности 


\section{РАЗВИТИЕ НАУКИ В ЭПОХУ ЦИФРОВИЗАЦИИ: ПРОБЛЕМЫ, ТЕНДЕНЦИИ, ПРОГНОЗЫ}

государства. Считанм, что в этой сфере скопилось немало проблем, которые требуют не столько осознания, сколько мудрого, незамедлительного разрешения. Выделим наиболее значимые. 1. Снижение качества образования в сфере национальной (военной) безопасности. Вся наша система подготовки исходит из военно-силовой природы безопасности. Но новые угрозы, такие как «экономические санкции» Запада после Крымских событий, по «Северному потоку-2», событий в Донбассе и Белоруссии после выборов президента в 2020 году, попытки политической изоляции России, последствия «украинского майдана», многочисленные акты международного терроризма, распространение ядерных технологий, саботаж поставок энергоресурсов, наркотрафик, миграционные потоки и некоторые другие не могут быть купированы усилиями только военных и дипломатов. Победа на поле боя не приводит к установлению прочного мира, а социальные последствия природных катастроф дестабилизируют целые регионы, где важную роль играют российские СМИ, вся информационная система страны. 2. Проблема методологии, инновационных технологий, моделирования и системы эффективного функционирования собственно «системы образования офицерских кадров силовых министерств и ведомств» как в ВС РФ, так и в отдельных видах (родах) войск. Реформа военного образования и проблемы, сопровождающие процесс профессиональной подготовки специалистов в интересах обороны и безопасности, наконец, стали объектом социально-политического и военно-педагогического анализа в теоретическом и практическом плане. Логика подсказывает, что в результате изменений в системе ВПО российский специалист (профессионал) должен стать лучше, чем тот, который выпускался до реформы. В противном случае ее проведение не имело бы смысла. Однако, вуз не должен готовить «человекафункцию». Ориентация на повышение профессиональных знаний и умений («компетентностная модель подготовки») не должна «отменить» или принизить главную образовательную цель - формирование личности, способной максимально реализоваться в выбранной профессии, личности с определенной гражданской позицией, личности, ориентированной на общественно-полезную деятельность. Умаление этой цели не соответствует интересам обороны и национальной безопасности государства. «Ремесленнических подход» в высшем профессиональном образовании только «сужает» предназначение высшей военной школы, понижает образовательную планку выпускников до «исполнительного уровня». 3. Выпускник военного учебного заведения, 


\section{РАЗВИТИЕ НАУКИ В ЭПОХУ ЦИФРОВИЗАЦИИ: ПРОБЛЕМЫ, ТЕНДЕНЦИИ, ПРОГНОЗЫ}

будущий командир и одновременно воспитатель, а не только специалистпрофессионал должен обладать навыками воспитательной и организаторской paботы в совершенно специфической обстановке жизнедеятельности войск. Таких специалистов общее высшее образование готовить не в состоянии, поскольку для получения штучного продукта, каким по определению является военный профессионал, Необходима отличная от гражданской система подготовки, обучения и воспитания, а также принципиально иная система жизни, то есть надо уметь и хотеть служить Родине, а не зарабатывать, в том числе $u$ за ее счет, как этому обучают в некоторых престижных гражданских вузах. 4. Образовательные стандарты для подготовки военных кадров должны быть принципиально иными, чем для подготовки гражданских специалистов, ориентированными не только на компетенции специалиста, но и на выработку морально-боевых, профессиональных и физических качеств личности офицера: человека с развитым чувством долга и чести, психологически устойчивого воина, командира-лидера, военного специалиста, учителя и воспитателя подчиненных. Если приоритетом становится выработка компетенций, а не морально-боевых качеств, то совершается методологическая ошибка, заключающаяся в приоритете средств над целями. При этом военный специалист создается как некая машина для войны без определенной духовной, нравственной и гражданской направленности. Что, как представляется, необходимо и возможно сделать? 1. Следует пересмотреть принятые нормативные акты о высшем образовании, отразить в них специфику военных вузов, сохранить традиции, которые складывались веками. Многие законодательные акты явились результатом лоббирования коммерсантов от науки и образования. Это очевидно и опасно, поскольку становится одним из направлений развала военной организации. Допустить этого нельзя. Нужен отдельный федеральный закон «О военно-профессиональном образовании». 2. Необходимо разработать и утвердить концепиию профессионального образования в сфере наииональной безопасности, где отразить взгляды государства, профессионального и вузовского сообщества на задачи и перспективы, стоящие перед системой образования. Определить основные принципы взаимодействия государства и негосударственных организаций в сфере подготовки специалистов в области национальной безопасности. Сформулировать требования к их подготовке и области применения. 3. Имеется настоятельная необходимость создать новую организационную структуру, возможно ассоциацию вузов, которая будет выступать в качестве площадки для 


\section{РАЗВИТИЕ НАУКИ В ЭПОХУ ЦИФРОВИЗАЦИИ: ПРОБЛЕМЫ, ТЕНДЕНЦИИ, ПРОГНОЗЫ}

диалога вузовского сообщества, государства и неправительственных организаций, выработки экспертных заключений и практических рекомендаций, будет способствовать обсуждению насущных проблем и выработке путей их решения. 4. Представляется возможным пересмотреть критерии оценки уровня подготовки и аттестации выпускника военного ВУЗа, повысив требования к его теоретическим знаниям, военно-прикладным навыкам, умениям и профессиональным компетенциям. Считаем целесообразным во всех военно-учебных заведениях по окончании теоретического курса, войсковой стажировки, защиты ВКР (дипломной работы) предусмотреть комплексный междисциплинарный в качестве ГОСУДАРСТВЕННОГО экзамен по теории и практике российской государственности. 5. Обеспечить на практике новое качество образования 8 интересах обороны и безопасности государства. Для этого не на словах, а практике изменить в сторону увеличения активный период работы военных научно-педагогических кадров. Необходимо новое Положение о прохождении службы должностных лиц, содержащее более существенные нормы стимулирования труда специалистов с ученой степенью и учеными званиями, научных работников, профессорско-преподавательского состава из числа офицеров и гражданского персонала. Профессорско-преподавательский состав учреждений военного профессионального образования должен иметь возможность вести свою работу последовательно и качественно, иметь достойную заработную плату. Эти мысли мы высказываем с завидным постоянством, а результатов позитивны изменений не наблюдаем, к великому сожалению. В целом, современные информационные технологии ведут к постепенному сокращению рабочих мест, высвобождению больших масс работников, исчезновению ряда профессий и данная тенденция со временем будет определяющей.

В качестве промежуточных выводов анализа проблемы отметим, что под давлением «цифровизации» меняются все сферы общественной жизни, которые необходимо учитывать и своевременно реагировать, учиться лучшему у других, а не на собственных ошибках, которых слишком много за три десятилетия уже совершили. Мы часто слышим понятие «цифровая диктатура». КНР еще в 1998 году приступила к строительству национального интернета «Золотой щит» и впоследствии «выдавила» из страны иностранные IT компании, заняв монопольное положение в национальном информационном пространстве. В начале 2010-х годов там начали внедрять систему «социального рейтинга », при 


\section{РАЗВИТИЕ НАУКИ В ЭПОХУ ЦИФРОВИЗАЦИИ: ПРОБЛЕМЫ, ТЕНДЕНЦИИ, ПРОГНОЗЫ}

которой искусственный интеллект отслеживает действия граждан, поощряя или наказывая в зависимости от их «государственного, общественного и социальносетевого поведения», в том числе кредиты, контакты и эмоции в социальных сетях, покупки, перемещения, поведение и работы [12]. То есть, политическая система стремится знать о гражданине Китая все... А выводы из этого делать нам!!! Существенное влияние процессы цифровизации оказывают не только на внешние составляющие человеческой жизни, но и на его внутренний, духовный мир. Мы видим реальное увеличение степени удовлетворенности духовных потребностей человека посредством практически неограниченного доступа для освоения ценностей, накопленных человечеством. Однако, другим следствием цифровизации является личностный кризис. Скорость и доступность информации сделали нас зависимыми от современных девайсов. Это приводит к примитивизации мышления, отсутствию воображения, принижению ценности целостного образования (учат только необходимые предметы, приобретают лишь требуемые компетенции), что, в свою очередь, ухудшает память, логическое мышление, ведет к «затмению» сознания. Результаты различных экзаменов, в том числе ГИА и ЕГЭ, демонстрируют процесс деградации естественных умственных способностей (интеллекта) большинства современной молодежи, что ведет к неадекватному восприятию мира у широких масс населения [13, с 141]. Генетик из Стэнфордского университета Джеральд Крэбтри, рассуждая об эволюции человеческого интеллекта, высказал интересную мысль: «Жизнь охотника доисторической эпохи напрямую зависела от его решений, крупная ошибка стоила ему жизни. Современный деятель с Уоллстрит, совершающий крупную ошибку, скорее всего, просто продолжит карьеру в другой компании, еще и получив приличные бонусы при увольнении» [14]. Чтобы успешно двигаться вперед, необходимо научить людей работать над собой, а для этого нужен личный и социально значимый стимул. К сожалению, налицо парадокс: несмотря на увеличение объема и доступности информации, мы не стали знать больше. Можно констатировать, что цифровизация привела современное человечество к духовному кризису, однако тревожит не сам кризис (так в истории бывало не раз), а отсутствие у большинства населения стремления найти выход из него. Таким образом, мы являемся активными участниками цифрового этапа информационной революции, оказывающего воздействие на нашу жизнь и объективную реальность. Его сущностными чертами выступают: внедрение цифровых технологий во все сферы жизни общества, ускоренный темп 


\section{РАЗВИТИЕ НАУКИ В ЭПОХУ ЦИФРОВИЗАЦИИ:

индивидуальной человеческой жизни, увеличение доступности информации, степени свободы во времени и пространстве для удовлетворения человеческих потребностей. Но также не стоит забывать о негативных чертах: усиление цифрового неравенства, возросшая зависимость человека от цифровых технологий, его изоляция в реальной жизни, увеличение разрыва между реальной и виртуальной реальностью, рост сторонников космополитизма, повышение угроз в сфере кибернетической безопасности, деградация естественного интеллекта. Насущной потребностью представителей социальной философии ныне выступает поиск новых сфер приложения человеческих знаний и сил, направление высвобождающегося в процессе цифровизации времени на создание дополнительных ценностей и улучшение качества жизни.

\section{Список литературы}

1. Андреев Н.А. Содержание феномена социальной ответственности в контексте строительства социального государства // Теории и проблемы политических исследований. - Вып.1А, -2020, Т.9, с. 74-80; Беляков Б.Л. Методология и методика научно-исследовательской деятельности или основы научной организации труда и профессионализации в Военной академии РВСН имени Петра Великого. Монография. - М.: ВА РВСН, 2014 - 267 с.; Дмитриева Т.В. Цифровой этап информационной революции: сущность, предпосылки и тенденции // Вестник Тверского государственного университета. Серия: философия. №4 (54), 2020. с.65-74.

2. Военная акмеология : Учебник / Под редакцией В.Г. Михайловского (Изд-е 2-е, переработанное и дополненное). Балашиха: ВА РВСН, 2020. - 459 с.

3. Ф3 № 149 от 27.07.2006 «Об информации, информационных технологиях и о защите информации» (в ред. 09.03.2021); Ф3 № 152 «О персональных данных» (в ред. от 30.12.2020) // [Электронный ресурс] http://www.profkadrovik.ru (дата обращения 13.04.2021). Программа «Цифровая экономика Российской Федерации». Утв. Распоряжением Правительства РФ от 28 июля 2017. №1632-p//Электронный pecypc.http://static.government.ru/media/ files/9gFM4FHj4PsB 79I5v7yLVuPgu4bvR7M0.pdf (дата обращения 13.04.2021)

4. Золотовская Л.А., Утробин Г. Ф. Чистяков А.Н. Методологическая основа подготовки адъюнктов к педагогической и исследовательской деятельности // Гуманитарный вестник ВА РВСН - 2020. - № 3 (20) - с. 112-119. 


\section{РАЗВИТИЕ НАУКИ В ЭПОХУ ЦИФРОВИЗАЦИИ:

5. Беляков Б.Л., Смирнов Е.В., Шинкевич В.Е. Наркотизация общества как угроза российской государственности: социально-философский анализ. Монография. - М.: Мос. А.П., 2014 - 323 с.

6. Терки Ш. Совместное одиночество. [Электронный ресурс]. URL. : http// psihologies. ru / standpoint / sherri - terki - ya -ne protiv - texnologiy - ya - za - razgovor (дата обращения 13.04.2021).

7. Беляков Б.Л. Военно-философский взгляд на проблему современной цивилизации. - Alma mater. Вестник высшей школы, 2016. Выпуск № 5 (май) c. 5-9.

8. Экономика шеринга в 30 цифрах и фактах / [Электронный ресурс]. URL:https://www.rbc.ru/trends/sharing/5ddbb3279a7947b01be74c19(дата обращения 10.04.2021)

9. Вестник военного образования (научно-методический журнал МО РФ) - Спец. выпуск, посвященный 200-летию ВА РВСН. - №6 (27) ноябрьдекабрь, 2020. - 125 с.

10. Беляков Б.Л., Шинкевич В.Е. Феномен патриотизма в социальногуманитарной научной традиции // Гуманитарный вестник ВА PBCH №1 (23),2021 - с 13-19.

11. Беляков Б.Л., Коннов А.Д., Нестеров В.В. Военно-педагогические проблемы профессионального образования в $\mathrm{PBCH} / /$ Международный научный институт «Educatio», Ежемесячный научный журнал №2 (20) - 2016. Часть 2 - с. 13-16.

12. Китай создал мир будущего и вам он не понравится / [Электронный pecypc]. https://zen.yandex.ru/media/space_for_you/kitai-sozdal-mir-buduscego-ivam-on-ne-ponravitsia-5dc137a804af1f00ae7ca21d (дата обращения 18.04.2020).

13. Беляков Б.Л., Иванова Е.В., Коннов А.Д. Социокультурные кризисы как угроза безопасности российского государства // Проблемы военной безопасности России в XXI веке: социально-гуманитарный анализ: монография. Балашиха: ВА РВСН, 2018. С.132-161.

14. Футуролог Харари назвал три главные угрозы человечеству в 21 веке / [Электронный pecypc]. https://www.rbc.ru/trends/futurology/5e2ef4499a 79474 925acdf08https: //www.rbc.ru/trends/futurology/5e2ef4499a79474925acdf08. (дата обращения 17.03.2021) 


\author{
ГЛАВА ІІ.
}

УДК 316.354:316.776

\title{
СОЦИАЛЬНО-ЦИФРОВЫЕ ПРАКТИКИ РОССИЙСКОЙ МОЛОДЕЖИ И ДИСТАНТНАЯ РАБОТА В УСЛОВИЯХ ПАНДЕМИИ КОРОНАВИРУСА
}

\author{
Василенко Инна Викторовна \\ д.филос.н., профессор \\ Волгоградский государственный университет \\ Василенко Илья Викторович \\ к. соц. н., доцент \\ Волгоградский филиал РЭУ им. Плеханова
}

\begin{abstract}
Аннотация: Данная статья посвящена рассмотрению социальных отношений молодых работников организаций в ходе выполнения ими трудовых функций в критической ситуации пандемии коронавируса. Эта ситуация потребовала более интенсивного внедрения и использования цифровых технологий в сфере труда, связанного с переходом на дистанционную форму. Результатом явились проблемы, связанные с конструированием социальноцифровых отношений в организациях. Эмпирической базой послужил on-line опрос.
\end{abstract}

Ключевые слова: критическая ситуация, пандемия коронавируса, дистанционная форма работы, социально-цифровые практики, трудовые, профессиональные и организационные последствия.

\section{SOCIAL AND DIGITAL PRACTICES OF RUSSIAN YOUTH AND REMOTE WORK IN THE CONTEXT OF THE CORONAVIRUS PANDEMIC}

Vasilenko Inna Viktorovna
Vasilenko Ilya Viktorovich

Abstract: This article is devoted to the consideration of the social relations of young employees of organizations in the course of their work functions in the critical 


\section{РАЗВИТИЕ НАУКИ В ЭПОХУ ЦИФРОВИЗАЦИИ: ПРОБЛЕМЫ, ТЕНДЕНЦИИ, ПРОГНОЗЫ}

situation of the coronavirus pandemic. This situation required a more intensive introduction and use of digital technologies in the field of work, associated with the transition to a remote form. The result was the problems associated with the construction of social and digital relations in organizations. The empirical basis was an on-line survey.

Key words: critical situation, coronavirus pandemic, remote form of work, social and digital practices, labor, professional and organizational consequences

\section{Введение}

Современное общество характеризуется переходом от отдельных электрических и электромеханических систем к электронным системам, дигитализацией коммуникации и информации, взрывным развитием программного обеспечения [2]. Основой этого общества становятся: информация, компьютерная техника и информационные технологии. Поэтому его часто называют информационным обществом. Все страны, включая Россию, в настоящее время включены в мировое информационное пространство, в котором стало проще и скорее хранить, обрабатывать и распространять информацию и знания. Все взаимоотношения агентов, использующих современные информационно-коммуникативные технологии, стали переноситься на язык цифр. На этой основе сформировались цифровые системы, которые можно определить, как социотехнические системы, включающие совокупность социальных взаимодействий агентов, опосредованных различными компьютерными программами. Связь пользователей с офисом, государственными структурами, сервисами может осуществляться непрерывно, в режиме реального времени, она может повторяться, быть многократной [8]. В результате появляются и развиваются новые социальные практики использования цифровых технологий и включения в виртуальное пространство сетей Интернет, основанные на комплексе взглядов и навыков агентов, используемых для удовлетворения различных видов потребностей [9].

Очевидную значимость цифровых средств коммуникации сегодня невозможно игнорировать. С их распространением происходят изменения, которые затрагивают повседневную жизнь людей, устоявшиеся социальные практики, способы, с помощью которых индивиды взаимодействуют друг с другом и с миром вокруг них. Меняется система формирования социального 


\section{РАЗВИТИЕ НАУКИ В ЭПОХУ ЦИФРОВИЗАЦИИ: ПРОБЛЕМЫ, ТЕНДЕНЦИИ, ПРОГНОЗЫ}

опыта в целом, все базовые основы процесса социализации [5]. Цифровые технологии позволили создать больше сетевых, совместных и основанных на широком участии форм социальных практик. Не случайно, М. Кастельс отмечал, что распространение сетей в значительной мере сказывается на ходе и результатах процессов, связанных с производством, трудом, повседневной жизнью, культурой, властью [4, с. 494].

Молодежь быстро и успешно адаптируется к новым технологиям и проникает в пространство цифровой системы, где формируется особая социотехническая среда и происходят процессы взаимодействия мира молодежи, вещей и информации. Социально-цифровые практики молодежи позволяют ей быстро осваивать новое информационное пространство, формировать цели на будущее, создавать тренды, формировать особые социальные отношения, способствующие интеграции молодежи в современное общество, организации, процессы труда, дающей молодым людям новые способы коммуникации и самореализации [1].

В таких условиях возрастает актуальность исследования социальноцифровой среды нового информационного пространства, факторов развития молодежных социальных практик в виртуальном пространстве Интернета с целью установления направления этого развития, его влияния на молодежь. Особенно актуальным является изучение этих практик в условиях экстремальных ситуаций, одним из примеров которой является пандемия коронавируса.

В современной науке феномен пандемии является слабо изученным вследствие необычности и непредсказуемости этого явления для всего человечества. [3, 7]. Уникальность данного явления заключается в том, что современный мир еще не сталкивался с ним и ни одна страна оказалась не готова к борьбе с ним. В настоящее время учеными предпринимаются усилия по оценке влияния пандемии коронавируса и самоизоляции, как следствия, на экономику, политические процессы, духовную жизнь, демографические тенденции [7]. Вполне очевидно, что последствия этого глобального события будут длительными и широкомасштабными, оценить которые в полной мере дело будущего.

Целью статьи является рассмотрение распространения и развитие дистанционных социальных практик российской молодежи в трудовой среде, 


\section{РАЗВИТИЕ НАУКИ В ЭПОХУ ЦИФРОВИЗАЦИИ: ПРОБЛЕМЫ, ТЕНДЕНЦИИ, ПРОГНОЗЫ}

опосредованных цифровыми технологиями и определение степени их освоения в условиях пандемии.

\section{Методология и методы}

Пандемия коронавируса создала такое состояние общества, которое можно назвать критическим, когда бедствия и потери становятся массово распространенными [6, с. 146]. Критические процессы влияют на все стороны жизнедеятельности человека и общества, ставят под угрозу здоровье и жизнь человека, его благополучие, состояние экономки и государства в целом. Вместе с тем, критические ситуации порождают ответную логику действий. В нашем случае, это уход людей в самоизоляцию и работа в удаленном формате. С одной стороны, самоизоляция позволяет обеспечить сохранение здоровья и жизни социальных агентов, а, с другой, обеспечить трудовую активность с использованием цифровой системы и развитием социальных практик взаимодействия в ней.

В качестве эмпирической базы использовались результаты on-line oпроса, выполненного с помощью метода анкетирования. Опрос проводился с помощью анкеты и посредством онлайн-сервера Google Documents на базе Google.com. Выборочная совокупность социологического исследования составила 276 человек. Из общего количества респондентов было опрошено $47 \%$ - представителей мужского пола, а также 53\% - представителей женского пола, что в целом отражает соотношение мужчин и женщин в современной России. В процессе проведения онлайн-опроса распределение респондентов по возрасту выглядело следующим образом: от 18-24 включительно (59,5\%); старше 24-34 включительно (32,4\%); старше 34-44 включительно (2,7\%); старше 44-54 включительно (2,7); старше 54 лет (2,7\%). Поскольку, преобладающая часть респондентов относится к категории «молодежь», то дальнейший анализ полученных результатов будет касаться только этой возрастной категории. Фактически тема исследования выступила в качестве «фильтра», отсекающего тех респондентов, которые мало используют информационные технологии, в том числе и удаленно.

Используемый при опросе инструментарий был разделен на четыре тематических блока: подготовка и использование цифровых технологий в труде, взаимодействие работника с цифровыми технологиями в условия пандемии, влияние использования цифровых технологий и удаленной работы 


\section{РАЗВИТИЕ НАУКИ В ЭПОХУ ЦИФРОВИЗАЦИИ: ПРОБЛЕМЫ, ТЕНДЕНЦИИ, ПРОГНОЗЫ}

на взаимоотношения респондента с организацией, коллегами, руководителем, наиболее острые проблемы при осуществлении удалённой работы.

\section{Результаты исследования}

Начнем анализ распространения и развития социальных трудовых практик в цифровой среде с перечня индикаторов, используемых в социологическом исследовании.

1. Тематический блок: «Подготовка и использование цифровых технологий в труде»

1.1. Отношение к дистанционной работе (оценка).

1.2. Оценка уровня знаний в области цифровых технологий.

1.3. Оценка обучения владению цифровыми технологиями в организации.

1.4. Выявление проблем при использовании цифровых технологий.

1.5. Перечень используемых цифровых платформ.

1.6. Определение используемых в дистанционном труде функций цифровых технологий.

1.7. Частота использования цифровых технологий до и во время пандемии коронавируса.

1.8. Тенденции изменения труда при использовании удаленной формы.

1.9. Удовлетворенность трудом в условиях использования цифровых технологий.

2. Тематический блок: «Взаимодействие человека и цифровых технологий в условиях пандемии»

2.1. Возможна ли трудовая деятельность без использования цифровых технологий для респондента.

2.2. Профессии, наиболее адаптируемые к условиям использования цифровых технологий в дистанционной форме труда.

2.3. Качества, необходимые работнику для построения успешной карьеры в условиях цифровизации и пандемии.

3. Тематический блок: «Влияние цифровых технологий и дистанционной работы на взаимоотношения работника и организации»

3.1. Влияние дистанционных форм труда на организацию в целом.

3.2. Влияние дистанционных форм труда на отношения с работодателем.

3.3. Последствия удаленной формы работы на отношения респондента с коллегами. 


\section{РАЗВИТИЕ НАУКИ В ЭПОХУ ЦИФРОВИЗАЦИИ: ПРОБЛЕМЫ, ТЕНДЕНЦИИ, ПРОГНОЗЫ}

3.4. Воздействие дистанционной формы труда на доход сотрудника.

3.5. Влияние дистанционной работы на дальнейшую трудовую деятельность респондента.

4. Тематический блок: «Наиболее острые проблемы при использовании удаленной формы трудовой деятельности».

\section{Подготовка и использование цифровых технологий в труде}

Дистанционные формы труда начали использоваться в условиях пандемии коронавируса для многих респондентов впервые. Поэтому важным является определение ожиданий от такой формы работы, общего настроения. Данные опроса показали, что преобладающая часть молодых респондентов (86,1\%) положительно относится $к$ дистанционной (удаленной) работе. Полученные результаты вполне объяснимы, так как в опросе приняли участие молодые респонденты, от 18 до 34 лет, которые, как показывали результаты ранее проведенных опросов, считаются очень активными пользователями интернет-технологий и потому никаких сложностей в их применении, в работе с ними у них, очевидно, за время удаленного труда не происходило. При этом, респонденты при включенности в дистанционную форму труда испытывали в большей степени именно положительные чувства и эмоции, такие как: радость и воодушевление (31,4\%), а также спокойствие и уверенность (42,9\%). Почти $1 / 3$ часть опрошенных призналась, что смешенных чувств в рассматриваемый период было больше, чем других эмоций. Еще 17\% отмечает полное равнодушие к данной новости, когда о ней им стало известно в начале пандемии и введенных в связи с ней ограничений. Волнение и боязнь испытали $14,3 \%$ респондентов. Таким образом, преобладающая часть респондентов была готова к труду в условиях удаленности.

Общая эмоциональная предрасположенность, конечно, очень важна для положительного отношения и уверенности в дистанционной работе, но значимым является также оценка опрошенными уровня своих знаний в этой области и возможности обучения тем аспектам новой по форме деятельности, которые респондентам были предоставлены. Подавляющее большинство опрошенных оценивает свой уровень знаний в области использования цифровых технологий, как высокий $(62,9 \%)$. Отметим, что оставшаяся часть опрошенных оценивает свой уровень владения цифровыми технологиями более скромно, как «средний». 
Только в четвертой части организаций было организовано обучение необходимым для удаленной работы технологиям. Большая часть респондентов была довольна качеством обучения. В то же время на остальных предприятиях обучение организовано не было. Хотелось бы отметить также, что преобладающая часть респондентов, работающих на них не хотела бы обучаться (рис. 1).

На наш взгляд, этот факт является крайне отрицательным, показывающим недопонимание важности качественного овладения цифровыми технологиями, а также наличие завышенной уверенности в своих знаниях и умениях. 80,0\% опрошенных заявили, что использование цифровых технологий не является для них проблемой.

После массового перехода на удаленный труд было ли организовано Вашим работодателем обучение цифровым технологиям для сотрудников?

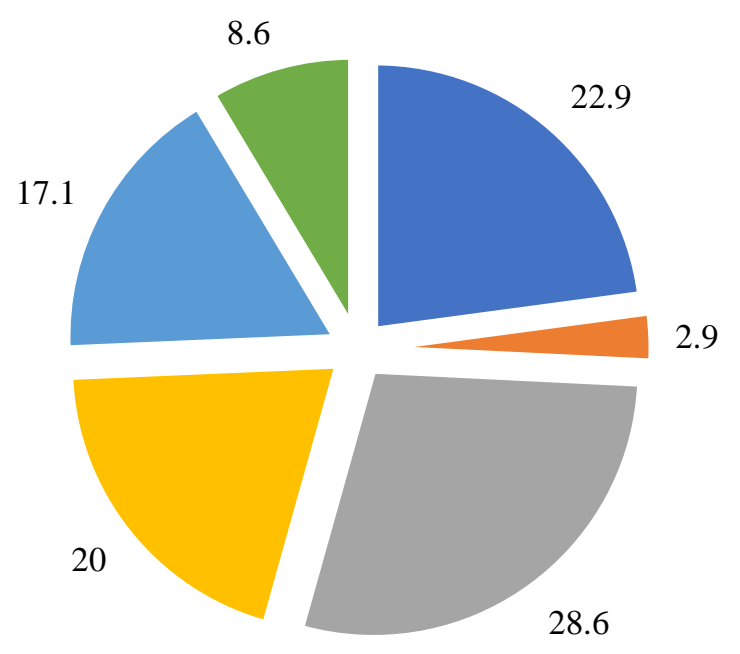

- 1. Да, было организовано и я остался(лась) этим обучением доволен(льна)

- 2. Да, было организовано и я остался(лась) этим обучением не доволен (льна)

- 3. Ничего об обучении в моей организации не было слышно

- 4. Нет, не было организовано и мне не очень хотелось бы

- 5. Нет, не было организовано, но очень хотелось бы

- 6. Затрудняюсь ответить

\section{Рис. 1. Организация обучения цифровым технологиям в организация респондентов}

С одной стороны, это может означать, что в цифровой среде молодые люди чувствуют себя уверено, в том числе, при выполнении служебных, трудовых функций, а, с другой, следствием может явиться недостаточная 


\section{РАЗВИТИЕ НАУКИ В ЭПОХУ ЦИФРОВИЗАЦИИ: ПРОБЛЕМЫ, ТЕНДЕНЦИИ, ПРОГНОЗЫ}

компетентность персонала в выполнении своих обязанностей в условиях критических ситуаций.

Для того, чтобы убедиться о соответствии уверенности респондентов в умении использовать цифровые технологии и реальностью задавался вопрос о том, какие цифровые платформы используются ими. В связи с переходом на удаленный труд, большинство опрошенных стали обращаться к различным облачным платформам для организации и проведения видеоконференций. Среди лидеров по степени популярности у респондентов выступают такие платформы, как «Zoom» (более 60,0\% респондентов), Microsoft Office 365 (более 40,0\%) респондентов и «Skype» (около 40,0\%). Помимо отмеченного, респонденты прибегают к регулярному использованию программ, позволяющих искать и анализировать изображения, переводить тексты (Google переводчик), чуть реже опрошенные обращаются за помощью к «умным» помощникам в процессе решения каких-либо рабочих вопросов (Autodesr eva, помощник в режиме 3D, который способен вести диалог с клиентом в режиме реального времени и имитировать соответствующие выражения лица) (рис. 2).

\footnotetext{
Скажите, пожалуйста, пользуетесь ли Вы в процессе выполнения своих трудовых обязанностей какими-либо цифровыми технологиями и если да, то какими?
}

$\begin{array}{lllll}0 & 20 & 40 & 60 & 80\end{array}$

1. Голосовые помощники (Alexa Amazon, Apple.

2. Умные помощники (Autodesk Eva, помощник в.

3. Облачная платформа «Zoom» для проведения.

4. Облачная платформа «Skype» для проведения.

5. Облачная платформа «Discord» для проведения.

6. Microsoft Office 365 (в т.ч. Microsoft Teams,.

7. Облачная платформа «VooV Meeting» для.

8. Языковые переводчики (Google переводчик и др.)

9. Поиск и анализ изображений (например, для. 10. Другое (напишите).

11. Не пользуюсь

\section{Рис. 2. Используемые цифровые платформы и программы}

Эти данные свидетельствуют о том, что далеко не все респонденты владеют в полной мере цифровыми платформами и программамипомощниками. Более того, каждая платформа имеет в своем арсенале множественные функции, поэтому важным представляется выяснить, насколько эффективно эти цифровые инструменты используются 


\section{РАЗВИТИЕ НАУКИ В ЭПОХУ ЦИФРОВИЗАЦИИ: ПРОБЛЕМЫ, ТЕНДЕНЦИИ, ПРОГНОЗЫ}

респондентами. С этой целью у респондентов спрашивали о том, какие функции платформ они используют. Около 70,0\% опрошенных используют цифровые технологии для поиска необходимой информации по работе и мессенджеры / социальные сети / электронные почты для коммуникации с коллегами или поставщиками. 60,0\% респондентов общаются с коллегами и поставщиками. Несколько меньшая доля опрошенных (34,3\%) используют цифровые технологии (во время обеденного перерыва) с целью поиска информации для самообразования. Около 9,0\% общаются с друзьями и родственниками. Таким образом, можно сделать вывод, что большинство пользователей цифровых платформ использует лишь десятую часть возможностей программ.

Картина применения цифровых технологий будет неполной, если не выяснить частоту употребления этих инструментов. Интересным представляется также сравнительный анализ применения цифровых технологий до пандемии и во время нее. И до, и в условиях пандемии большинство респондентов использовали цифровые технологии ежедневно и еженедельно, правда, в период удаленного труда и введенного режима самоизоляции, регулярность использования несколько возросла: так, до пандемии и удаленного труда 22,9\% опрошенных использовали технологии несколько раз в течение недели, в то время, как с такой же регулярностью, но в период пандемии 25,7\% респондентов стали прибегать к цифровым технологиям. А вот частота использования технологий на ежедневной основе возросла почти в 1,5 раза (с 45,7\% до 65,7\%), что, безусловно, может быть обусловлено только переходом на дистанционную форму труда и проведением досуга в домашних, «цифровых» условиях. Анализ полученных данных показал следующую тенденцию в использовании цифровых технологий: резко увеличилась частота использования их ежедневно, еженедельное использование осталось на прежнем уровне, а вот более редкие случаи применения цифровых технологий резко сократились: респонденты «включились» в социально-цифровые практики.

Поскольку эти практики связаны с трудовыми процессами, выполнением трудовых функций одной из задач, которая ставилась, было определение возможных изменений в труде при использовании дистанционных форм. Но сначала надо было выяснить смысл труда вообще для респондентов (респондентам разрешалось выбрать три ответа). Более 70,0\% опрошенных 


\section{РАЗВИТИЕ НАУКИ В ЭПОХУ ЦИФРОВИЗАЦИИ: ПРОБЛЕМЫ, ТЕНДЕНЦИИ, ПРОГНОЗЫ}

считают, что труд для них - это источник заработка. 65,0\% видят в труде средство удовлетворения также социальных и духовных потребностей. Для 20,0\% опрошенных труд служит источником удовлетворения потребностей, но не занимает важное место в жизни. Понятно, что это учащаяся молодежь, которая еще не включилась в трудовые процессы в полной мере. Ведь известно, что большинство студентов старших курсов в настоящее время параллельно с учёбой работают. 5,0\% респондентов считают труд неприятной необходимостью и если бы была возможность не работать, то они не работали бы. Выяснив общую картину отношения к труду у респондентов, участвующих в опросе, переходим к определению возможных изменений отношения к труду в условиях использования цифровых технологий и пандемии.

Цифровые технологи для более, чем 60,0\% респондентов сделали труд намного проще, чем когда-либо (рис. 3). Однако, по мнению 31,4\% опрошенных, труд остался неизменным даже после перевода труда в дистанционную форму. В этом случае возможны следующие варианты объяснений. Вероятнее всего, для данной группы опрошенных свойственно в большей степени поддерживать социальные контакты в реальной среде, в режиме реального времени, а также осуществлять другие трудовые обязанности без особого использования технических средств и технологий. В то же время возможен вариант, в котором респонденты не испытывают трудностей при использовании цифровых технологий и использовали их ранее, поэтому трудовые функции для них не изменились.

Обратим снимание на тот факт, что для большинства опрошенных труд с использованием цифровых технологий не стал сложнее. 


\section{РАЗВИТИЕ НАУКИ В ЭПОХУ ЦИФРОВИЗАЦИИ: ПРОБЛЕМЫ, ТЕНДЕНЦИИ, ПРОГНОЗЫ}

Как изменился Ваш труд при использовании цифровых технологий?

$\begin{array}{lllllllllll}0 & 5 & 10 & 15 & 20 & 25 & 30 & 35 & 40 & 45 & 50\end{array}$

1. Труд стал определенно проще, чем до использования цифровых технологий

2. Труд стал скорее проще с использованием технологий, чем сложнее

3. Труд не изменился с использованием цифровых технологий

4. Труд стал скорее сложнее с использованием технологий, чем до их использования

5. Труд стал определенно сложнее после начала использования цифровых технологий

6. Затрудняюсь ответить

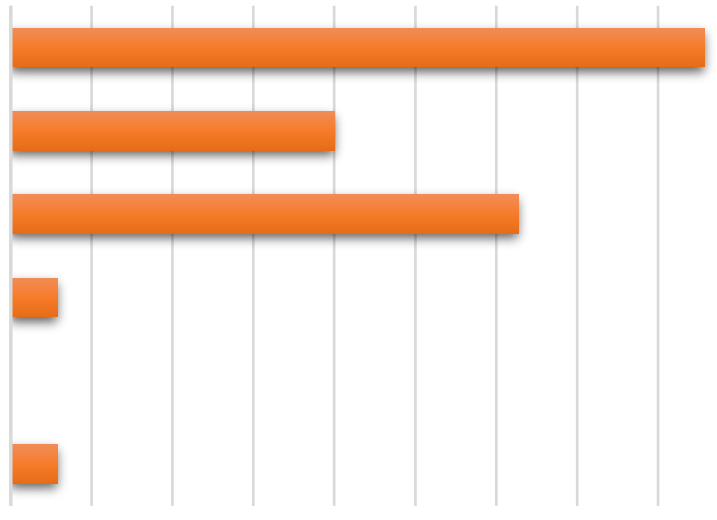

\section{Рис. 3. Тенденции изменения труда в условиях дистанционной формы труда}

Из общей оценки смысла труда и изменения его сложности вытекает вопрос об удовлетворенности трудом, которое испытывают респонденты. Удовлетворены своей работой более половины опрошенных $(65,7 \%)$, что сказывается на их желании не менять постоянное место работы (51\% респондентов не собирается уходить со своей настоящей работы). 8,6\% участников опроса отметили, что в их организации не удовлетворительные условия и организация труда, и потому они планируют в скором времени заняться поисками нового места работы. 25,7\% заняли нейтральную позицию, однако часть из них высказала желание уйти с работы. Причины следующие: низкий уровень заработной платы $(22,9 \%)$, напряженность и утомляемость в выполнении трудовых функций $(20 \%)$, отсутствие возможностей для профессионального продвижения, карьерного роста и личностного развития $(17,1 \%)$. При этом респонденты уверяют, что дистанционная работа и использование цифровых технологий не сказались на их желании поменять место работы.

Взаимодействие человека и цифровых технологий в условиях пандемии

В ходе on-line опроса был сделан также акцент на изменениях некоторых аспектов трудовой деятельности респондентов из-за дистанционных форм работы. 


\section{РАЗВИТИЕ НАУКИ В ЭПОХУ ЦИФРОВИЗАЦИИ: ПРОБЛЕМЫ, ТЕНДЕНЦИИ, ПРОГНОЗЫ}

Несмотря на удаленный труд, некоторая часть опрошенных $(14,3 \%)$, отмечает, что их трудовая деятельность может осуществляться и без помощи цифровых технологий. Однако более половины респондентов $(63,1 \%)$ придерживаются мнения о том, что их трудовая деятельность теперь неразрывно связана с цифровыми технологиями и для того, чтобы построить успешную карьеру в настоящих условиях развития пандемии, необходимо, в первую очередь, уметь работать с помощью данного вида технологий, а также иметь качественную профессиональную подготовку и большое терпение.

Цифровые технологии и развитие социально-цифровых практик в трудовой деятельности сформировали новые требования к человеку труда, стремящегося сделать успешную карьеру в современных условиях. Выделенные респондентами качества выстроены в порядке приоритета. На первом месте располагается такое качество, как умение работать с цифровыми технологиями $(74,3 \%)$. На втором месте - усердная работа и терпение $(65,7 \%)$. Третье место отдано респондентами качественной профессиональной подготовке (62,9\%). Далее следуют: наличие социального капитала (связи, «нужные» знакомства, умение строить отношения с людьми) $(42,9 \%)$, постоянное повышение квалификации (20,0\%). Остальные качества набрали по 2,9\%: престижное образование, привлекательная внешность и личное обаяние. 2,9\% опрошенных затруднились высказать свое мнение.

Умение работать с цифровыми технологиями было отмечено как самое главное качество современного человека труда. Какие же профессии наиболее адаптивны к таким критически ситуациям как пандемия коронавируса? Логично, что такими профессиями будут IT-специалисты (94,3\%). Далее называют группы экономических и педагогических профессий: экономист, финансист, бухгалтер (54,3\%) и преподаватель, учитель (45,7\%). Меньшую адаптивность, по мнению опрошенных, имеет профессия менеджера $(28,6 \%)$. Приведенные данные демонстрируют следующие неоднозначные последствия для различных профессий, вытекающие из данной критической ситуации. Вопервых, это цифровое неравенство, которое проявляется в разном доступе и уровне знаний в области цифровых технологий (60,0\%). Во-вторых, несмотря на рост востребованности медицинских специалистов в критических ситуациях, подобных настоящей, большинство респондентов полагает, что врачи не являются достаточно адаптивными специалистами к социально-цифровым 


\section{РАЗВИТИЕ НАУКИ В ЭПОХУ ЦИФРОВИЗАЦИИ: ПРОБЛЕМЫ, ТЕНДЕНЦИИ, ПРОГНОЗЫ}

практикам и воспользоваться преимуществами дистанционного формата труда не смогут.

\section{Влияние цифровых технологий и дистанционной работы на взаимоотношения работника и организации}

В этой части исследования выявлялись последствия перехода на социально-цифровые практики в трудовых процессах для организации и работников.

Многие опрошенные затруднились определить влияние критической ситуации пандемии на организацию. Однако определённая информация об этом имеется: 25,0\% опрошенных постарались высказать свое мнение. Так, 15,0\% респондентов считают, что развитие организации никак не связано с пандемией и дистанционной работой. У 20,0\% сформировались прямо противоположные мнения. 10,0\% отметили улучшение развития организации и ровно столько же ухудшение. Подобная неактивность респондентов и противоречивые оценки связаны скорее с незнанием ситуации. Иное дело, когда речь идет об оценке взаимодействий с ближайшим окружением, например, с работодателем. По оценкам более половины респондентов $(51,4 \%)$ отношения не изменились. В то же время 37,2\% опрошенных отмечают ухудшение отношений, а вот улучшение могут констатировать лишь 11,4\%. Это свидетельствует о том, что руководители организаций не учли новую критическую ситуацию и не перестроились на новые условия. Примерно такая же тенденция наблюдается при оценке последствий дистанционной работы для отношений с коллегами. Более половины $(54,3 \%)$ считают, что ничего не изменилось. Ухудшение отношений отмечают $31,4 \%$, а улучшение - 14,3\%. В связи с полученными данными можно прийти к выводу, что знание и освоение цифровых технологий является необходимым, но недостаточным условием успешного функционирования организаций и выполнения трудовой деятельности их работников. Нужно умело выстроить социально-цифровые отношения, то есть социальных отношения, опосредованные использованием цифровых технологий. Именно в этом аспекте не все удалось организациям по причине отсутствия должного внимания этому вопросу.

Следующая задача касалась влияния дистанционной формы труда на доход респондентов. Более 20,0\% респондентов считают, что уровень их доходов не изменился. Для $8,0 \%$ опрошенных он улучшился после перехода на удаленную форму труда, а для 7,0\% - ухудшился. Несколько иная картина 


\section{РАЗВИТИЕ НАУКИ В ЭПОХУ ЦИФРОВИЗАЦИИ: ПРОБЛЕМЫ, ТЕНДЕНЦИИ, ПРОГНОЗЫ}

прослеживается при оценке перспектив своей трудовой деятельности. 15,0\% опрошенных думают, что перспективы не изменились. $15,0 \%$ считают, что перспективы улучшились и только 5,0\% отмечают ухудшение перспектив своей трудовой деятельности. Поскольку ответили на эти вопросы не все респонденты, а только небольшая часть, проценты приводятся только для отображения общей тенденции.

Наиболее острые проблемы при использовании удаленной формы трудовой деятельности

В качестве наиболее актуальных проблем, появившихся в условиях пандемии и дистанционного труда респонденты отметили четырнадцать моментов, которые можно разделить на три группы. Первая группа включает профессиональные и трудовые проблемы, вторая - проблемы, связанные с организацией труда, а третья - проблемы, связанные с цифровыми технологиями и их использованием.

В первую группу проблем включены: отсутствие вакансий в определенных сферах трудовой деятельности, неконкурентоспособность многих профессий.

Ко второй группе можно отнести: низкую оплату труда, неудобный график работы, рост объемов работы и трудовых обязанностей, увеличение рабочей нагрузки за более низкую заработную плату, халатное отношение работодателя к правам и обязанностям работников, принуждение работников уходить в отпуск без содержания; невозможность уйти для некоторых работников на удаленный режим работы (не разрешает руководитель); замораживание повышений в организации.

Третья группа образуется такими проблемами, как: слабо развитые цифровые технологии во многих организациях; отсутствие цифровой грамотности у многих людей; отсутствие технических возможностей для осуществления рабочего процесса в удаленном формате (дома).

\section{Заключение}

Естественные процессы развития информационного общества привели к созданию мирового информационного пространства, основой которого явились: информация, компьютеры и информационные, или цифровые технологии. Пандемия коронавируса создала во всех странах критическую ситуацию, приносящую угрозы и потери здоровья, дохода, места работы. В этих условиях развитие и использование цифровых технологий позволило 


\section{РАЗВИТИЕ НАУКИ В ЭПОХУ ЦИФРОВИЗАЦИИ:

снизить критичность ситуации за счет самоизоляции людей и перевода трудовых процессов в дистанционную форму. Особенно распространились цифровые технологии среди молодежи, поэтому в трудовой сфере молодые работники не встретились с большими трудностями при использовании цифровых возможностей. В целом ряде российских организаций в условиях дистанционной работы сформировались социально-цифровые практики взаимодействия с работодателем, коллегами. Исследование показало, что далеко не на всех предприятиях было организовано обучение новым цифровым платформам, поэтому большинство использует незначительное число функций этих программных инструментов. Если взаимодействие молодых работников с цифровыми технологиями можно признать в целом нормальным, то социальноцифровые отношения между работниками и другими социальными агентами оказались вне контроля руководства организации, поэтому в ряде организаций ухудшились. Потеря руководством контроля над ситуацией в организациях в критической ситуации подтверждается перечнем выделенных респондентами проблем, большая часть которых относится к организационным проблемам.

\section{Список литературы}

1. Акопов, С.В. Сетевая философия и трансформация идентичности личности // Управленческое консультирование. - 2013. - № 12. - С. 42-47.

2. Бехманн Г. Современное общество: общество риска, информационное общество, общество знаний. - М.: Логос, 2010. - 248 с.

3. Емельянова Е.Н. Особенности психологической помощи в ситуации пандемии коронавируса // Управление социально-экономическими системами: теория, методология, практика. Сборник статей VII Международной научнопрактической конференции. - Пенза: МЦНС «Наука и просвещение, 2020. C. $142-145$.

4. Кастельс М. Становление общества сетевых структур. Новая постиндустриальная волна на Западе: антология / под ред. В. М. Иноземцева. M.: Akademia, 1999. - 640 c.

5. Таллер М. Дискуссии вокруг Digital Humanities // Историческая информатика. Информационные технологии и математические методы в исторических исследованиях и образовании. - 2012. - № 1 (1). - С. 5-13.

6. Яницкий О.Н. Социология риска. - М.: Издательство LVS - 192 с. 
7. Кулькова И.А. Влияние пандемии коронавируса на демографические процессы в России // Human Progress. - 2020. - Том 6. - Выпуск 1. - URL: http://progresshuman.com/images/2020/Tom6_1/Kulkova.pdf, свободный. DOI 10.34709/IM.161.5

8. Begon M., Harper J., Townsend C. Ecology: Individuals, Populations and Communities. - Cambridge: Blackwell Publishing, 1996. - 750 p.

9. Miller, Vincent Understanding digital culture. London: Sage., 2011. - 254p. 
ГЛАВА ІІІ.

\section{ПРАКТИКА ПРОФЕССИОНАЛЬНОЙ ПОДГОТОВКИ \\ МАГИСТРОВ ПЕДАГОГИЧЕСКОГО ОБРАЗОВАНИЯ ПРИ ФГБОУ ВО «ДАГЕСТАНСКИЙ ГОСУДАРСТВЕННЫЙ ПЕДАГОГИЧЕСКИЙ УНИВЕРСИТЕТ» И СПЕЦИАЛИСТОВ ПРИ ГАОУ ВПО «ЮГО-ОСЕТИНСКИЙ ГОСУДАРСТВЕННЫЙ УНИВЕРСИТЕТ ИМЕНИ А.А.ТИБИЛОВА» В УСЛОВИЯХ ЦИФРОВИЗАЦИИ ОБРАЗОВАНИЯ}

Везиров Тимур Гаджиевич доктор педагогических наук, профессор ФГБОУ ВО «Дагестанский государственный педагогический университет»

Козаева Гульнара Ролландовна кандидат педагогических наук ГАОУ ВПО «Юго - Осетинский государственный университет имени А.А. Тибилова»

Аннотация: В главе представлены результаты практической реализации системы подготовки магистров педагогического образования и специалистов в Республиках Дагестан и Южная Осетия. Рассмотрены некоторые аспекты подготовки магистров по профилю «Информационные и коммуникационные технологии в образовании» и специалистов в условиях цифровой трансформации образования, где особую роль играют цифровые образовательные ресурсы, цифровые сервисы, как составляющие цифровой образовательной среды вуза. Представлены некоторые авторские цифровые образовательные ресурсы, которые используют студенты магистратуры ФГБОУ ВО «Дагестанский государственный университет» и цифровые сервисы и инструменты, которые применяют будущие специалисты ГАОУ ВПО «Юго Осетинский государственный университет имени А.А. Тибилова».

Ключевые слова: магистры, специалисты, магистерская программа, цифровая образовательная среда, цифровые инструменты и ресурсы, цифровой ресурс, сетевой учебный курс. 


\title{
THE PRACTICE OF PROFESSIONAL TRAINING OF MASTERS \\ OF PEDAGOGICAL EDUCATION AT THE DAGESTAN STATE PEDAGOGICAL UNIVERSITY AND SPECIALISTS AT THE SOUTH OSSETIAN STATE UNIVERSITY NAMED AFTER A. A. TIBILOV IN THE CONTEXT OF DIGITALIZATION OF EDUCATION
}

\section{Vezirov Timur Gadzhievich Kozaeva Gulnara Rollandovna}

\begin{abstract}
The chapter presents the results of the practical implementation of the system of training masters of pedagogical education and specialists in the Republics of Dagestan and South Ossetia. Some aspects of training of masters in the field of "Information and communication technologies in education" and specialists in the conditions of digital transformation of education, where a special role is played by digital educational resources, digital services, as components of the digital educational environment of the university, are considered. Some author's digital educational resources used by master's students FSBEI HE "Dagestan State University" and digital services and tools used by future specialists are presented State Autonomous Educational Institution of Higher Professional Education "South Ossetian State University named after A.A. Tibilov".
\end{abstract}

Key words: masters, specialists, master's program, digital educational environment, digital tools and resources, digital resource, network training course.

Среди существующих когнитивной, личностно ориентированной, функционалистской, культурологической парадигм образования в современной педагогике рассматривают также и цифровую парадигму образования. Под цифровой парадигмой образования И.В. Роберт понимает совокупность теоретико-методологических, научно-педагогических положений и технологических решений, которые ориентированы на интеллектуальное развитие личности с использованием цифровых технологий в образовательном процессе [4].

Происходящая цифровая трансформация образования является глобальной тенденцией и парадигма «обучение через всю жизнь» не может осуществляться без совершенствования системы подготовки специалистов на основе использования современных цифровых технологий. 


\section{РАЗВИТИЕ НАУКИ В ЭПОХУ ЦИФРОВИЗАЦИИ: ПРОБЛЕМЫ, ТЕНДЕНЦИИ, ПРОГНОЗЫ}

Выделяются следующие тенденции цифровой трансформации процессов в системе образования:

- использование дополненной, виртуальной и смешанной реальностей;

- применение цифровых пользовательских устройств в учебном процессе;

- использование искусственного интеллекта;

- персонализация учебного процесса и его геймификация.

Цифровизация образования всегда должна включать в себя создание новых, более эффективных процессов обучения и преподавания. Цифровые инструменты в образовании всегда должна приносить пользу педагогике, обогащать преподавание и увеличивать его методическое разнообразие, тем самым предоставляя обучающимся предпосылки для изучения нового материала.

Как отмечают авторы статьи [2] Р.В. Мещеряков, А.П. Назаренко и В.К. Сарьян, этап цифровизации связан тем, что современные информационнокоммуникационные технологии (ИКТ) способствуют формирование гиперсвязанного мира, который позволяет рационализировать все стороны жизни, в том числе, по-новому проводить обучение, уделяя большое внимание междисциплинарности.

Внедрение цифровых инструментов и сервисов в образовательный процесс вуза позволит:

- создать индивидуальную образовательную траекторию студента;

- реализовать принцип интерактивности;

- создавать образовательную кооперацию.

Цифровая трансформация образования, которая связана с освоением новых цифровых инструментов и сервисов развивается, по мнению А.Ю. Уварова, по следующим линиям:

- обучаемые осваивают новые цифровые инструменты и сервисы, а также развивают алгоритмическое мышление;

- трансформируются содержание, методы и формы учебной работы;

- образовательные организации осваивают их для повышения эффективности образовательного процесса;

- педагоги и руководители образования также их осваивают [5].

Цифровые инструменты сопровождают изменения, которые позволяют улучшить образовательный процесс и образовательные результаты. 


\section{РАЗВИТИЕ НАУКИ В ЭПОХУ ЦИФРОВИЗАЦИИ: ПРОБЛЕМЫ, ТЕНДЕНЦИИ, ПРОГНОЗЫ}

Новые цифровые инструменты и сервисы требуют от специалиста профессионализма на волне цифровой трансформации образования. Исследователи считают, что цифровые инструменты могут быть:

- представлены программными продуктами для управления образовательным процессом;

- организации учебного процесса;

- представления учебного материала;

- фиксации профессиональных действий;

- учета достижений.

В учебный процесс все чаще включаются следующие цифровые сервисы:

- различные цифровые инструментальные обучающие среды - от мобильных приложений до коллаборативных онлайн-платформ;

- игры;

- тренажеры;

- виртуальные модели;

- онлайн-лаборатории;

- среды для визуального программирования, обработки данных;

- сервисы для создания и работы над ученическими портфолио;

- множество онлайн-сервисов.

Учитель - главный ресурс системы образования, без которого ничего не пойдет, включая «цифру».

Без активного участия специалистов цифровая трансформация образования не состоится, на которую влияют внутренние (изменение целей, содержания, методов, форм обучения) и внешние (политические, экономические, технологические, культурные) факторы.

Важную роль в системе подготовки специалистов играют следующие цифровые учебные материалы:

1. В Единой коллекции цифровых образовательных ресурсов (http://scoolcollection.edu.ru) размещены ЦОР по общеобразовательным и специальным учебным дисциплинам.

2. Портал «Единое окно доступа к образовательным ресурсам» (http://window.edu.ru) предоставляет свободный доступ к каталогу образовательных интернет-ресурсов и полнотекстовой электронной 


\section{РАЗВИТИЕ НАУКИ В ЭПОХУ ЦИФРОВИЗАЦИИ: ПРОБЛЕМЫ, ТЕНДЕНЦИИ, ПРОГНОЗЫ}

учебно-методической библиотеке для общего и профессионального образования.

3. Портал «Единый государственный экзамен» (http://ege.edu.ru) является примером цифровизации одного из элементов образовательного процесса, где письменные ответы каждого выпускника школы сканируются и их цифровой образ передается в Федеральный центр тестирования.

4. Федеральный центр информационно-образовательных ресурсов (ФЦИОР) (http://fcior.edu.ru) поддерживает распространение ЭОР и сервисов для всех ступеней и уровней образования.

И.В. Роберт в своей статье [4, с.42] описывает позитивные и негативные изменения в сфере современного образования в связи с активным и систематическим применением цифровых технологий в образовательных целях, обосновывая определения цифровой трансформации и цифровой парадигмы образования с указанными изменениями, а также представляет стратегические ориентиры и дает им характеристику. К таким ориентирам относятся:

- методологические;

- теоретические;

- технологические;

- гуманитарно-прикладные.

По мнению автора, предложенные новые теории обучения и современные технологии по реализации конвергенции педагогической науки и цифровых технологий, по созданию и информационно-образовательного пространства образовательной организации и др. позволят учителю грамотно решать методические проблемы и осуществлять меры по предотвращению возможных негативных последствий цифровой трансформации образования.

C помощью цифровых технологий можно решать следующие образовательные задачи:

- быстрый поиск информации с еe визуализацией, графическая интерпретация, обработка;

- адаптация информационных систем к новым технико-технологическим условиям;

- интеллектуализация информационной деятельности и информационного взаимодействия участниками образовательного процесса;

- автоматизация всех видов контроля результатов образовательной деятельности. 


\section{РАЗВИТИЕ НАУКИ В ЭПОХУ ЦИФРОВИЗАЦИИ: ПРОБЛЕМЫ, ТЕНДЕНЦИИ, ПРОГНОЗЫ}

Выделяют такие возможности цифровых технологий в сфере образования, как: предоставление образовательных услуг; создание цифровых образовательных ресурсов; информационная безопасность личности.

Важную роль в цифровой трансформации образования играет цифровая образовательная среда вуза [5].

В такой среде заметной становятся развитие и внедрение дистанционных образовательных технологий и электронного обучения, которые дают широкие возможности для управления учебной деятельностью, формируют новый характер взаимодействия преподавателя и студентов, а также обеспечивают интерактивный способ обучения.

Преподаватель использует возможности цифровых технологий, как составляющих цифровой образовательной среды вуза, для обеспечения ему сформировать у студентов мотивацию и познавательный интерес.

Как отмечает Т.О. Пучковская, расширение использования цифровых технологий вызывает повышение спроса на новые цифровые навыки специалиста, а также выдвигаются новые требования к профессиональной компетентности педагога в условиях трансформации процессов в системе образования [3].

В области профессионализма 22 компетенции, объединенные в шесть таких тематических областей, как: «Профессионализм»; «Цифровые ресурсы»; «Обучение»; «Оценка»; «Расширение прав и возможностей обучающихся»; «Развитие цифровой компетенции обучающихся», разработанные Европейской комиссией, направлены на использование цифровых технологий для организации коммуникации и улучшения профессионального взаимодействия, развитие рефлективной практики, а также для использования цифровых источников в непрерывном профессиональном развитии [6].

В условиях пандемии актуально стало онлайн-обучение, представляющее собой способ организации процесса самостоятельного изучения учебных материалов с использованием образовательной среды, основанной на интернеттехнологиях, обучение с помощью сети Интернет и мультимедиа.

Проблема реализация онлайн-обучения находится в настоящее время в условиях цифровизации образования, где происходят смена парадигм и образовательных технологий, изменение содержания, форм и методов педагогического процесса. 


\section{РАЗВИТИЕ НАУКИ В ЭПОХУ ЦИФРОВИЗАЦИИ: ПРОБЛЕМЫ, ТЕНДЕНЦИИ, ПРОГНОЗЫ}

Для организации онлайн-обучения применяются такие цифровые сервисы, как: ленты времени; интерактивные карты; виртуальные доски, которые применяются для решения образовательных задач.

Важной составляющей цифровой образовательной среды вуза является онлайн-курсы, размещенные на ресурсе «Одного окна» - это как каталог лучшего образования на данный момент. В нем размещены более 200 онлайнкурсов, которые соответствуют самым высоким требованиям высшей школы и работодателей.

Студенты магистратуры на факультете математики, физики и информатики ФГБОУ ВО «Дагестанский государственный педагогический университет», обучающиеся по магистерской программе «Информационные и коммуникационные технологии в образовании», проходят обучение по онлайнкурсу «Цифровые инструменты сервисы для учителя», включающий разделы:

1. Введение.

2. Цифровые технологии в образовании.

3. Дистанционные образовательные технологии.

4. Цифровой образовательный контент.

5. Инструменты и сервисы для поддержки образовательного процесса.

6. Заключение.

7. Список использованной литературы.

Автором данного онлайн-курса является профессор С.В. Панюкова. Данный онлайн-курс размещен на платформе Stepik. После обучения студенты получают сертификаты.

Ведущим компонентом цифровой образовательной среды вуза являются цифровые инструменты и сервисы.

Одним из таких инструментов является образовательная платформа 4portfolio.ru, где осуществляется процесс использования дистанционного и смешанного обучения, а также проектная и исследовательская деятельность магистрантами, обучающиеся по магистерской программе «Информационные и коммуникационные технологии в образовании» под руководством профессора Т.Г. Везирова.

Магистранты создают личные веб-странички на портале 4portfolio.ru для общения и обсуждения изучаемого материала.

Для изучения конкретной дисциплины блока «Предметная часть» учебного плана подготовки магистров по магистерской программе 


\section{РАЗВИТИЕ НАУКИ В ЭПОХУ ЦИФРОВИЗАЦИИ: ПРОБЛЕМЫ, ТЕНДЕНЦИИ, ПРОГНОЗЫ}

«Информационные и коммуникационные технологии в образовании» на данном портале создали сообщество магистрантов, которое предоставляет им дополнительные сервисы для дискуссии, взаимодействия, совместной работы.

Здесь важное место занимает высоконасыщенная предметная цифровая образовательная среда, где одной из составляющей является цифровой учебный материал, который играет педагогическую роль в реализации основной программы магистратуры по направлению подготовки 44.04.01 Педагогическое образование, магистерская программа «Информационные и коммуникационные технологии в образовании».

Предметная цифровая образовательная среда ФГБОУ ВО «Дагестанский государственный педагогический университет» в образовательном процессе магистратуры при изучении дисциплин блока «Предметная часть» учебного плана пополняются новыми цифровыми учебными материалами.

К таким дисциплинам относятся:

1. Теория и методика информатизации образования.

2. Цифровая образовательная среда

3. Средства информационных и телекоммуникационных технологий в педагогическом образовании.

4. ИКТ-компетентность педагога.

5. Портальные технологии в педагогическом образовании.

6. Мобильное обучение.

7. Виртуальная и дополненная реальности.

Использование сетевых курсов, как одной из составляющих цифровой образовательной среды вуза, получает все большее распространение в преподавании различных дисциплин.

Нами разработан сетевой учебный курс по дисциплине «Портальная технология в педагогическом образовании», включающий:

1. Инструктивный блок, где описывается цель изучения дисциплины, организация учебного процесса, а также методические рекомендации по самостоятельному изучению данного курса.

2. Информационный блок, где рассматривается учебный материал и структура учебного курса.

3. Коммуникативный блок, включающий: электронные семинары; консультации; дистанционные практикумы; лабораторные работы.

4. Контрольный блок, содержащий тестовый и рейтинговый контроль в авторизованном режиме. 


\section{РАЗВИТИЕ НАУКИ В ЭПОХУ ЦИФРОВИЗАЦИИ:

5. Сетевое взаимодействие, включающее: вебинар; чат; форум; контакты.

В образовательном процессе магистратуры используется цифровой ресурс «Цифровая образовательная среда», который имеет следующую структуру:

1. Введение.

2. Теоретический блок.

3. Практический блок.

4. Контрольный блок.

5. Глоссарий.

6. Литература.

7. Об авторах.

Данные цифровые образовательные ресурсы будущими магистрами используются в процессе организации смешанного обучения, которое нами рассматривается как средство обучения, позволяющий осуществлять дистанционную поддержку очного обучения, самостоятельную работу студентов магистратуры и при написании магистерской диссертации.

Студенты магистратуры к прохождению научно-педагогической практики в общеобразовательных организациях Республики Дагестан изучают содержание школьного курса информатики и готовят дидактические учебные материалы с использованием таких современных образовательных технологий, как ментальные карты, которые являются графическим представлением информации, позволяющие проводить совместную работу. При создании ментальных карт студентами магистратуры применяются такие цифровые инструменты, как:

- Mindmeister (https://www.mindmeister.com), позволяющий делиться ментальными картами с любым количеством учеников, сотрудничать с ними в реальном времени, а также позволяет преобразовать ментальные карты в динамичные слайд-шоу и вставить презентацию на сайт.

- Xmind (https://xmind.net), позволяющий визуально организовать причинно-следственные связи между сложными идеями или событиями.

Рассмотрим практику использования цифровых инструментов и сервисов в профессиональной подготовке специалистов педагогики и психологии при ГАОУ ВПО «Юго-Осетинский государственный университет имени А.А. Тибилова». 


\section{РАЗВИТИЕ НАУКИ В ЭПОХУ ЦИФРОВИЗАЦИИ: ПРОБЛЕМЫ, ТЕНДЕНЦИИ, ПРОГНОЗЫ}

Современное общество и деловая жизнь давно цифровизованы, но образовательные организации в Республике Южная Осетия только делают первые шаги, чтобы стать цифровыми.

Использование цифровых инструментов в преподавании и обучении в образовательных организациях Республики Южная Осетия осуществляется систематически, исходя из стратегических целей учебной программы и учебного заведения.

В настоящее время объемы электронного контента увеличиваются оцифровываются учебники, разрабатываются онлайн-курсы. Использование электронных ресурсов при обучении, это не только шаги в образовании в ногу со временем, но и требования, прописанные в федеральных государственных образовательных стандартах РФ, которые используются и в Республике Южная Осетия. Общеизвестно, что с сентября 2015 года все школьные учебники сегодня должны иметь электронные версии.

Электронный образовательный контент дал обучающимся образовательных организаций Республики Южная Осетия больше возможностей получать знания самостоятельно, ориентироваться в больших объемах информации- это именно то качество, которое необходимо и для работодателей в цифровой экономике. Таким образом, цифровизация помогает в обучении, она делает занятия интересными, а главное - более продуктивными. Здесь учитель становится тьютором и наставником.

Большое значение для саморазвития имеют и цифровые платформы для учителя - также средство на пути к пониманию собственной стратегии образования. Они помогают развить soft skills, умение работать в команде, критически мыслить и выражать свою точку зрения.

Единственное высшее учебное заведение в Республике Южная Осетия Юго-Осетинский государственный университет имени А.А.Тибилова (ЮОГУ) был отстроен заново в рамках реализации финансируемых Россией Инвестиционных программ содействия социально-экономическому развитию республики. Здание выполнено по новейшим стандартам и оснащено всем необходимым для развития вуза. В ЮОГУ созданы все условия для развития цифровизации учебного процесса. Однако цифровое обучение только набирает обороты. Наличие постоянного интернета в вузе позволяет легко найти преподавателю полезный учебный контент. Благодаря наличию смартфонов у 90\% обучающихся в вузе развивается новая коммуникативно-информационная 


\section{РАЗВИТИЕ НАУКИ В ЭПОХУ ЦИФРОВИЗАЦИИ: ПРОБЛЕМЫ, ТЕНДЕНЦИИ, ПРОГНОЗЫ}

культура, которая ориентирована на мобильные и «мелкоформатные» (с небольшим экраном и облегченными версиями сайтов) образовательные ресурсы.

Среди преподавателей образовательных организаций Республики более 70\% регулярно применяют цифровые технологии в своей работе. При этом около 60\% демонстрируют в классе видеоматериалы из различных источников (чаще YouTube). Около $48 \%$ используют общепринятые цифровые инструменты, такие как Microsoft Office и Google G SuiteforEducation, около $12 \%$ - веб-сайты и приложения, которые позволяют создавать и обмениваться полезным контентом. Это связано в том числе с тем, что практически все образовательные организации имеют высокоскоростной доступ к Интернету.

Для развития цифрового обучения в ЮОГУ были организованы внутренние курсы повышения квалификации для преподавателей по информационной компетентности; курсы по программированию в рамках проекта ЕДХ Гарвардского университета. Курсы были направлены на то, чтобы преподаватели могли грамотно использовать цифровые инструменты в обучении и преподавании.

Одним из популярных цифровых инструментов, применяемых для контроля знаний учащихся в образовательном процессе ЮОГУ, является Kahoot. Это сервис для создания онлайн-викторин, тестов и опросов. Создание своего собственного урока в этом сервисе занимает считанные минуты. Есть возможность выбрать уже готовый материал из огромного количества шаблонов.

Обучающиеся могут отвечать на созданные учителем тесты с планшетов ноутбуков, смартфонов, то есть с любого устройства, имеющего доступ к интернету.

Созданные в Kahoot задания позволяют включить в них фотографии и видеофрагменты. Темп выполнения тестов и викторин осуществляется путем введения временного предела для каждого вопроса. Учитель может ввести баллы за ответы на поставленные вопросы. Табло отражается на мониторе учительского компьютера. Kahoot используется не только в ЮОГУ, но и некоторыми преподавателями в профессиональных образовательных организациях, в частности, в многопрофильном колледже. Образовательный сервис Kahoot позволяет более качественно проводить обучение по специальностям и профессиям «Строительство и эксплуатация зданий и сооружений», «Мастер по обработке цифровой информации» и др. 


\section{РАЗВИТИЕ НАУКИ В ЭПОХУ ЦИФРОВИЗАЦИИ: ПРОБЛЕМЫ, ТЕНДЕНЦИИ, ПРОГНОЗЫ}

Цифровое обучение в ЮОГУ состоит из онлайн-обучения и систематической работы с учебными заданиями. Задачи обучения определяют, как студенты обрабатывают информацию, как они учатся. Поэтому целью учебных заданий является изучение нового, а не проверка того, что уже изучено.

Ещё одним ключевым элементом цифрового обучения является создание знаний. Студенты ЮОГУ объединяют и конструируют новые для себя знания, используя разные источники: веб-страницы, книги, журналы или личный опыт и наблюдения. Создание новой информации - важнейшая задача цифрового обучения. Процесс создания новой информации достаточно увлекателен для студентов и способствует отложению и закреплению полезной информации в памяти, развитию IT навыков, общему развитию.

Одним из популярных цифровых учебных платформ, используемых в ЮОГУ, а также многими преподавателями многопрофильного колледжа в Республике является ТорНаt - универсальная учебная платформа, которая позволяет преподавателям создавать интересные и интерактивные презентации с целью повышения активности обучающихся. Эта образовательная платформа имеет достаточно перспектив для регулярного еe использования в образовательном процессе ЮОГУ. Она дает возможность использования в презентации разнообразных мультимедийных элементов. Педагог может проверить знание предмета, использовать встроенные оценочные мероприятия. Инструмент полезен для регулярного контроля знаний после прохождения очередной темы или раздела, чтобы сразу же определить уровень понимания темы и плохо усвоенный материал, выявить учащихся, которые испытывают трудности. Данный цифровой образовательный ресурс может удовлетворить тягу к человеческому общению с помощью интерактивного чата, который работает как внутри класса, так и снаружи, позволяет поддерживать сотрудничество студентов после занятий с помощью чата или видеоконференции и проводить виртуальные рабочие часы в любое время и в любом месте. Используя данный цифровой ресурс имеется возможность выбора одного из тысяч доступных, высококачественных интерактивных учебников, которые можно настроить в соответствии с потребностями.

ТорНат позволяет создать свои собственные материалы курса и воплотить их в жизнь с помощью видео, симуляций, интерактивных домашних заданий и многого другого. Каждое взаимодействие - посещаемость, участие, задания, тесты - автоматически фиксируется в зачетной книжке TopHat. 


\section{РАЗВИТИЕ НАУКИ В ЭПОХУ ЦИФРОВИЗАЦИИ: ПРОБЛЕМЫ, ТЕНДЕНЦИИ, ПРОГНОЗЫ}

Педагог легко может получить представление об успеваемости каждого студента и понять, кто добивается успеха, а кто нуждается в дополнительной поддержке.

Данный цифровой инструмент активно используется преподавателями инженерно-экономического факультета вуза, а также методистами многопрофильного колледжа.

Оба цифровых сервизов используются достаточно регулярно в учебном процессе вуза и колледжа.

В последние годы внимание общественности, образовательных организаций Республики Южная Осетия привлечено к общедоступным открытым онлайн-курсам Massive Open Online Courses (MOOCs), или МУКам . Массовые открытые онлайн-курсы, или МУКи отличаются от традиционных дистанционных учебных курсов тем, что количество записывающихся на курс слушателей не ограничено, курс является общедоступным (Massive). Аудиторию таких курсов иногда составляют до несколько тысяч, материалы курса могут использоваться всеми желающими. Здесь слово «открытый» означает, что на курс может бесплатно записаться любой пользователь Интернета, независимо от возраста, дохода, знания языка и уровня образовательной подготовки. Курс использует дистанционные образовательные технологии, и для его изучения обучающимся и преподавателям необходим доступ в Интернет (online). Курс может использовать и другие возможные формы очной и заочной учебной работы, однако на практике их набор ограничен доступными интернет-сервисами. Изучение курса является отдельным законченным учебным мероприятием (Course). Он включает явное описание ожидаемых образовательных результатов, материалы и инструменты для учебной работы, инструменты и процедуры итогового оценивания слушателей, а также их сертификацию. Имеется несколько разновидностей МУКов, основные из них -xМООСs и cМООСs. Разработчики МУКов придерживались знаниевой парадигмы организации учебного процесса (изложение преподавателем нового материала, его закрепление, контрольные вопросы и т.п.).

Работа с МУКами требует, чтобы у слушателей курса была сформирована способность к самостоятельной учебной работе.

Среди образовательных онлайн-площадок, которые предлагают МУКи в России, в Республике Южная Осетия популярным становится образовательная 


\section{РАЗВИТИЕ НАУКИ В ЭПОХУ ЦИФРОВИЗАЦИИ: ПРОБЛЕМЫ, ТЕНДЕНЦИИ, ПРОГНОЗЫ}

платформа «Открытое образование». На ней собраны массовые онлайн-курсы ведущих российских вузов, которые могут предоставить всем желающим возможность бесплатно записаться на онлайн-курсы, подготовленные в ведущих университетах России, а также зачесть результаты этого обучения в своем университете. Платформа «Открытое образование» предлагает более 250 учебных курсов по разным темам. На курсах обучаются многие преподаватели вуза и многопрофильного колледжа. Курсы дают возможность пройти качественное обучение за короткое время, что позволяет экономить время и ресурсы.

Наиболее востребованы курсы по управлению персоналом, а также по бухгалтерскому учету.

В ЮОГУ и многопрофильном колледже использование вышеуказанных цифровых инструментов и сервисов при подготовке специалистов происходит путем смешанного обучения, что не является простым сочетанием традиционных аудиторных и электронных форм обучения. В процессе обучения происходит замещение части традиционных учебных занятий различными видами учебного взаимодействия в электронной среде для организации эффективной работы в виртуальном образовательном пространстве. В смешанном обучении используются как готовые цифровые ресурсы, так и ресурсы, созданные самими преподавателями и студентами. Больше всего обучающихся привлекают комплексные электронные ресурсы, совмещающие в себе учебный контент, отвечающий требованиям вариативности форм представления информации, и цифровые инструменты для организации учебной деятельности. Цифровые образовательные ресурсы позволяют размещать на одном носителе разнообразные ресурсы - учебники, методические рекомендации и др.. Они обеспечивают компактное размещение больших объемов учебных материалов с помощью разных уровней вложенности гипертекста и дают возможность представить информацию в разных формах, например текстовой, мультимедийной, графической. Гипертекстовая структура представления информации помогает обучающимся осуществлять навигацию по содержанию, быстрый поиск, возможность нахождения контекстных подсказок и корректив. При такой форме обучения часть познавательной деятельности студентов осуществляется в аудитории под непосредственным руководством преподавателя, а часть деятельности выносится в онлайн с преобладанием самостоятельных видов работ 


\section{РАЗВИТИЕ НАУКИ В ЭПОХУ ЦИФРОВИЗАЦИИ: ПРОБЛЕМЫ, ТЕНДЕНЦИИ, ПРОГНОЗЫ}

индивидуально. Получается естественное продолжение учебного процесса, в котором преподаватель проводит консультации и проверочные работы. Данная форма обучения предоставляет также широкие возможности для использования материалов открытых образовательных ресурсов, онлайн-курсов различных платформ, цифровых инструментов для разгрузки аудиторных занятий от рутинных видов учебной работы, при которой больше времени на занятиях посвящается обсуждениям трудных тем и заданий. Такая форма обучения проводится, в частности, при изучении зкономических дисциплин в ЮОГУ.

Проблема в том, что реализация данной формы обучения требует большой методической подготовки преподавателей, в которую входят отбор и конструирование содержания учебного материала для работы в Интернете и для проработки учебного материала на занятиях в аудитории. Необходима адаптация содержания учебного материала для онлайн-обучения в соответствии с выбранной педагогической технологией, организация разных форм взаимодействия студентов с преподавателем и другими студентами. Несмотря на то, что в процессе использования цифровых технологий в образовании студентам приходится сталкиваться с проблемами и трудностями, связанными с недостаточной развитостью культуры умственного труда в Интернете, они понимают, что цифровые технологии оказывают огромное влияние на интеллектуальную и коммуникативную деятельность студентов. Развивающий потенциал Интернет-технологий, цифровых сервисов и инструментов состоит в предоставлении пользователям широких возможностей для развития навыков новых видов исследовательской, интеллектуальной деятельности, для формирования самообразовательных компетенций.

Наблюдения показали, что использование цифровых сервизов и инструментов оказывает как положительное, так и отрицательное влияние на обучающихся. Например, как отмечают сами студенты, работа с указанными цифровыми сервисами приучила их к самостоятельности. Также, по их мнению, такое обучение в дальнейшем сделает их характер более твердым. По мнению студентов, без излишней заботы педагогов можно добиться более высоких результатов.

Важным моментов для обучающихся также является отсутствие бумажной волокиты и экономия на бумажных версиях учебных инструментов.

Преподаватели считают, что использование цифровых инструментов в образовании упрощает их работу. В цифровой системе работа педагога 


\section{РАЗВИТИЕ НАУКИ В ЭПОХУ ЦИФРОВИЗАЦИИ: ПРОБЛЕМЫ, ТЕНДЕНЦИИ, ПРОГНОЗЫ}

подразумевает лишь помощь. Педагог задает направление, по которому развиваются обучающиеся, они обращаются к нему лишь в спорных ситуациях.

Несомненным плюсом использования цифровых инструментов в образовании преподаватели и обучающиеся назвали шаг в будущее. Цифровизация обучения помогает лучше ориентироваться в информационном мире в будущем.

Отметим, что основная цель цифрового обучения не в технологии, а в том, что информационные технологии, как метод, делают возможным новое в обучении и преподавании. Информационно-коммуникационные технологии позволяют использовать методы, способствующие обучению, которые не могут быть реализованы на практике иначе.

Использование цифровых инструментов помогает разгрузить аудиторные занятия от рутинных видов учебной работы, при которой больше времени на занятиях посвящается обсуждениям трудных тем и заданий. Это особенно актуально при подготовке специалистов инженерно - экономических специальностей в вузе, а также при подготовке специалистов среднего профессионального образования.

Еще один цифровой инструмент, который в перспективе может быть использован и в системе образования - интеллектуальный голосовой помощник «Залина», разработанный в Республике Северная Осетия-Алания. Согласно сообщению республиканского управления по ИТ-технологиям и связи, «Залина» вошла в число лучших цифровых практик России. О нем заявили на всероссийском совещании в Министерстве цифрового развития, связи и массовых коммуникаций России. В базе знаний «Залины» пока только множество вопросов и ответов по коронавирусной тематике. Далее планируется развить голосовой помощник полезной информацией в сфере образования. По мнению экспертов, в перспективе «Залина» станет дополнительным цифровым инструментом для пополнения знаний и быстрого получения качественной информации для обучающихся.

Таким образом, значимость цифровых компетенций, важных как для социальной, так и для профессиональной составляющей каждого специалиста в Республике Южная Осетия, возрастает с каждым годом. Потому что цифровые компетенции приобретают особую актуальность в сегодняшних социально экономических условиях. 


\section{РАЗВИТИЕ НАУКИ В ЭПОХУ ЦИФРОВИЗАЦИИ:

\section{Список литературы}

1. Везиров Т.Г., Бабаян А.В. Профессиональная подготовка магистров педагогического образования средствами электронного обучения: монография. - Ульяновск: Зебра, 2015. - 140 с.

2. Мещеряков Р.В., Назаренко Р.В., Сарьян В.К. Проблемы и возможности гиперсвязанного мира // V международная конференция «Инжиниринг \& Телекоммуникации - En\&T 2018». - М., 2018. - C.124-135.

3. Пучковская Т.О. Новые требования к компетенциям педагога в условиях цифровой трансформации процессов в образовании // Информатизация образования - 2020. Материалы Международной научнопрактической конференции, посвященной 115 - летию со дня рождения патриарха российского образования, великого педагога и математика, академика РАН С.М. Никольского. - Орел, 2020. - С.122-127.

4. Роберт И.В. Стратегические ориентиры развития информатизации образования в условиях цифровой трансформации // Информатизация образования - 2020. Материалы Международной научно-практической конференции, посвященной 115 - летию со дня рождения патриарха российского образования, великого педагога и математика, академика РАН С.М. Никольского. - Орел, 2020. - С.42-59.

5. Федеральный проект «Цифровая образовательная среда» [Электронный ресурс]. - Режим доступа: https://futurerussia.gov.ru/ cifrovaaobrazovatelnaa-sreda

6. Уваров А.Ю. Образование в мире цифровых технологий: на пути к цифровой трансформации. - Изд.дом ГУ-ВШЭ, М.: 2018. - 168 с.

7. Redecker C. European Framework for tre Dgital Competence of Educators: DigCompedu. Punie, Y. (ed). EUR 28775 EN. Publications Office of the European Union, Luxembourg, $2017-95$ p. 


\title{
ГЛАВА IV.
}

\section{МОТИВАЦИЯ ПРОФЕССИОНАЛЬНОГО СТАНОВЛЕНИЯ БУДУЩЕГО УЧИТЕЛЯ В УСЛОВИЯХ ПРИМЕНЕНИЯ ДИСТАНЦИОННЫХ ТЕХНОЛОГИЙ}

\author{
Рахманова Алсу Рамилевна \\ к.п.н., старший преподаватель \\ Ахтариева Разия Файзиевна \\ к.П.н., доцент \\ Салимуллина Елена Викторовна \\ старший преподаватель \\ Шапирова Раиля Равильевна \\ старший преподаватель \\ Елабужский институт (филиал) ФГАОУ ВО КФУ
}

\begin{abstract}
Аннотация: В данной работе рассматривается особенность дистанционного обучения, требующего от системы образования специального подхода к повышению профессиональной мотивации будущих педагогов. Так же востребованность в применении инновационных технологий, которые призваны поднять эффективность проведения учебных занятий, способствующих формированию удовлетворенности обучающихся организацией образовательного процесса, а также создать определённые условия для профилактики здоровья обучающихся. Именно инновационные технологии должны способствовать повышению качества подготовки будущих специалистов, что является необходимой составляющей профессиональной мотивации учителя.
\end{abstract}

Ключевые слова: мотив, профессиональная мотивация, информатизация образования, дистанционное обучение. 


\title{
MOTIVATION OF PROFESSIONAL FORMATION \\ OF A FUTURE TEACHER IN THE CONDITIONS OF APPLICATION OF REMOTE TECHNOLOGIES
}

\author{
Ahtarieva Raziya Fajzievna \\ Rakhmanova Alsu Ramilevna \\ Salimullina Elena Viktorovna \\ Shapirova Railya Ravilevna
}

\begin{abstract}
The article speaking about the peculiarity of distance learning, which requires a special approach from the education system to increase the professional motivation of future teachers. There is also a demand for the use of innovative technologies that are designed to increase the effectiveness of training sessions that contribute to the formation of students 'satisfaction with the organization of the educational process, as well as create certain conditions for the prevention of students' health. It is innovative technologies that should contribute to improving the quality of training of future specialists, which is a necessary component of the teacher's professional motivation.
\end{abstract}

Key words: motive, professional motivation, informatization of education, distance learning.

Педагогическую деятельность можно причислить к ряду профессий наиболее эмоционально и интеллектуально напряжённых. В последние годы она всё чаще связана с различными экстремальными ситуациями, условиями расплывчатости и изменчивости, что требует от педагогов единства их профессионально-важных качеств личности.

Данные факторы предъявляют к педагогу требования, с одной стороны, осуществлять педагогическую деятельность стабильно, длительно и с высоким уровнем производительности, с другой стороны - адаптироваться к внезапным требованиям, использовать своеобразные способы решения возникающих проблем, обладать гибкостью поведения. Таким образом, от учителя требуется, с одной стороны, устойчивость компонентов личности, с другой - их гибкость [20, с.39].

Еще недавно специалисты прогнозировали, каково будет изменение облика современного образования под влиянием цифровых технологий и 


\section{РАЗВИТИЕ НАУКИ В ЭПОХУ ЦИФРОВИЗАЦИИ: ПРОБЛЕМЫ, ТЕНДЕНЦИИ, ПРОГНОЗЫ}

каким будет отклик действующей системы образования на цифровой вызов. Пандемия стала катализатором стремительных изменений. В связи с зарождением новой современной пандемии COVID-19 и предотвращением её распространения всю систему образования на время перевели на дистанционное обучение. Особенность дистанционного обучения потребовало от системы образования специального подхода и к повышению профессиональной мотивации педагогов. Усилилась востребованность в применении инновационных технологий, которые призваны поднять эффективность проведения учебных занятий, способствовать формированию удовлетворенности обучающихся организацией образовательного процесса, а также создать определённые условия для профилактики здоровья обучающихся. Именно инновационные технологии должны способствовать повышению качества подготовки педагогов, что является необходимой составляющей профессиональной мотивации [5, с.17].

Анализ психолого-педагогической литературы показал достаточную разработанность разных аспектов указанной проблемы: дистанционные образовательные технологии применяются и в очной, и в заочной формах обучения, что позволяет повысить доступность и качество обучения студентов, а проблема мотивации профессионального становления будущего учителя в условиях применения дистанционных технологий остается малоизученной.

Новые технологии обучения, устремлённые на повышение активности будущих педагогов в организации учебно-познавательной деятельности в условиях дистанционного обучения, будут способствовать повышению мотивации к изучению дисциплин их профессиональной деятельности.

Профессиональная мотивация - это «действие конкретных побуждений, которые обусловливают выбор профессии и продолжительное выполнение обязанностей, связанных с этой профессией. Она формируется под влиянием факторов окружающей действительности, работы по профориентации» $[22$, c.21].

Мотивация - сложная система мотивов, которая стимулирует, регулирует и поддерживает любую деятельность человека.

В психологии по-разному трактуется понимание мотива. А.Н. Леонтьев утверждает, что мотив - это потребность объекта, которая заставляет его действовать, а конкретнее, направляет его деятельность [там же, с. 23]. 


\section{РАЗВИТИЕ НАУКИ В ЭПОХУ ЦИФРОВИЗАЦИИ: ПРОБЛЕМЫ, ТЕНДЕНЦИИ, ПРОГНОЗЫ}

«Мотив, - по словам Л.И. Божович, - отличается от цели, т.к. цель определяет деятельность, а мотив побуждает к ней» [22, с.27].

С.Л. Рубинштейн заявлял, что мотив может отделяться от цели, перемещаться на деятельность или на его результат. Иногда второстепенный по цели результат может стать субъективным для человека. Он через достигнутую цель может перейти к другому мотиву действия.

Значит, мотив - это источник деятельности любого человека. Мотивы (интересы, потребности, стремления, убеждения, идеалы, эмоции, влечения, инстинкты, установки) - это то, что побуждает человека к деятельности, ради чего она совершается. У каждого человека своя мотивация.

«Мотивация - это побуждение, которое активирует деятельность субъекта, определяет его направленность. Оно обуславливает поведение, деятельность человека, воздействует на его профессиональное самоопределение» [21, с.536-540].

Мотивация выступает как необходимый компонент профессионального образования и является одной из составляющих профессиональной компетентности будущего специалиста. Чтобы выявить внутренние резервы успехов в обучении будущих специалистов своего дела, исследуют мотивацию их учебной деятельности, условия и средства обучения. Именно они оказывают огромное влияние на мотивационную сферу субъекта. Профессиональная мотивация - это движущаяся сила. На её основе возможно эффективное развитие профессиональной культуры человека. Если рассматривать значение термина «профессиональная мотивация» по отношению к учебной деятельности студентов, то оно понимается как «совокупность факторов и процессов, которые, отражаясь в сознании, побуждают и направляют личность к освоению будущей профессиональной деятельности» [5, с.73].

Характеристика мотивации профессиональной деятельности, по мнению многих педагогов и психологов, выражается в побуждении. Если конкретнее, то в интересах, отношениях, усилиях профессиональной направленности субъекта. Профессиональный интерес связан с мотивационной сферой, регулирует его внешнее выражение, определяет всё, что происходит в ней. А.К. Маркова писала: «через профессиональные ценности, цели и мотивы, а также профессиональные операции (способности, технологии) можно определить профессионализм субъекта» $[5$, с.82]. 


\section{РАЗВИТИЕ НАУКИ В ЭПОХУ ЦИФРОВИЗАЦИИ: ПРОБЛЕМЫ, ТЕНДЕНЦИИ, ПРОГНОЗЫ}

Профессиональный интерес зарождается на этапе выбора профессии. Данный этап избирателен, выражается в активности личности в отношении будущей профессии. В.Ф. Сахаров, П.И. Костюшина и другие отмечали, что важен не только выбор профессии на первичной стадии, но и стремление удерживать данный интерес на протяжении всей профессиональной деятельности [Error! Reference source not found., c.61].

Обучение студента в учреждениях высшего звена является важным этапом профессионального становления личности, где наиболее актуальна профессиональная мотивация, которая побуждает и направляет деятельность субъекта по освоению профессии. Деятельность, максимально приближённая к профессиональной, обеспечивает выстраивание иерархии мотивов, где ведущими должны становиться профессиональные мотивы.

Вследствие этого, подготовка специалистов педагогического профиля заключается в формировании таких коммуникативных умений, которые позволили бы ему осуществлять профессиональные контакты в различных сферах и ситуациях, способствовали формированию стремлений и способностей будущего учителя, обладающего высокой коммуникативной компетенцией, стилем профессионально-ориентированной деятельности. Причём, ставится и задача приобретения общих знаний по специальности, профессии. Соответственно, процесс обучения в профессиональной школе должен быть ориентированным на конкретную аудиторию подготовленных специалистов. Педагогический процесс должен предполагать смещение акцента на профессионально-мотивационный аспект и обеспечивать углубление профессионального компонента в содержании обучения предмету. Выбор форм, методов, средств обучения должны развивать интерес и потребность в труде, способствовать созданию ситуаций профессионального характера [5, c.94].

Процесс обучения в вузе должен быть насыщен эмоционализацией, обогащающей ценностно-мотивационную сферу личности и развивающей положительное отношение к профессиональной деятельности. Личностнопрофессиональная позиция будущего учителя - это способность мотивировать себя к получению профессионального образования. Успешность профессиональной мотивации студентов зависит от удачной педагогической поддержки. 


\section{РАЗВИТИЕ НАУКИ В ЭПОХУ ЦИФРОВИЗАЦИИ: ПРОБЛЕМЫ, ТЕНДЕНЦИИ, ПРОГНОЗЫ}

Слияние внешних и внутренних мотивов, единство мотивов и целей (осознание будущей специализации, профессии) есть важная предпосылка формирования положительного отношения к будущей профессии.

Обобщая вышесказанное, можно выделить несколько ключевых моментов профессиональной мотивации в становлении будущего педагога:

1) Интегративный характер мотивации, который может быть сформирован именно в период обучения в вузе.

2) Профессиональная культура, без овладения которой невозможна продуктивная профессиональная деятельность педагога.

3) Единое наличие целей мотивационного, когнитивного, ценностного и эмоционального компонентов профессиональной деятельности.

4) Устойчивость эмоциональных реакций: способность регулировать эмоциональные переживания, управлять эмоциональным состоянием других объектов образовательного процесса.

5) Способность длительно и на высоком уровне выполнять профессиональную деятельность в любых условиях (даже в стрессовых).

6) Саморазвитие, самосовершенствование как компоненты профессиональной мотивации педагога [7, с.23-26].

Таким образом, в процессе формирования положительной профессиональной мотивации необходимо учитывать особенности определения факторов мотивации. Причём наблюдается определённая система мотивов, их соподчинение и порядок расположения в системе (иерархия). И всё это обусловлено психологическими особенностями юношеского возраста как этапа развития профессионального сознания. Кроме того, следует иметь ввиду и индивидуальные особенности каждой личности студентов. Образ жизни студентов, их образование и общение формируют отношения, образ действия и характер субъекта, которые подчинены определенным причинам и отличаются от других групп и коллективов молодёжи.

Мотивация будущего учителя заключается во внутренней мотивации, его должно интересовать содержание того, чем он занимается. Именно внутренняя мотивация побуждает педагога к активности, ему должно нравится выполнять свою профессиональную деятельность. Мы предполагаем, что развитие профессиональной мотивации будущих педагогов в условиях дистанционного обучения будет эффективно при применении инновационных технологий. 


\section{РАЗВИТИЕ НАУКИ В ЭПОХУ ЦИФРОВИЗАЦИИ: ПРОБЛЕМЫ, ТЕНДЕНЦИИ, ПРОГНОЗЫ}

Современное образование в России в настоящее время всё больше внимания концентрирует на потенциале использования в учебном процессе различных технологий передачи информации. Следовательно, одно из приоритетных направлений в работе вуза - это создание и постоянное расширение системы дистанционного обучения (далее ДО) студентов. Методика применения ДО в образовательных учреждениях всех уровней образования Российской Федерации определено рядом утверждённых нормативно-правовых актов и законов.

Образовательные организации, реализующие образовательные программы, в соответствии с Федеральным законом «Об образовании в Российской Федерации» от 29 декабря 2012 года (ст. 16) должны создать «... условия для функционирования электронной информационно-образовательной среды, включающей в себя электронные информационные ресурсы, электронные образовательные ресурсы, совокупность информационных технологий, телекоммуникационных технологий, соответствующих технологических средств для освоения обучающимися образовательных программ в полном объёме независимо от места нахождения» [1].

В соответствии с приказом Министерства образования и науки РФ при организации учебного процесса с применением дистанционных образовательных технологий «...все обучающиеся должны обеспечиваться образовательным учреждением или располагать собственными (либо арендованными) учебными рабочими местами, оснащёнными для реализации данного обучения. Под учебным рабочим местом, оснащённым для дистанционного обучения, понимается компьютер со средствами мультимедиа и выходом в Интернет для проведения всех видов учебных занятий, текущего контроля знаний и промежуточной аттестации. Каждому преподавателю должны быть обеспечены возможность взаимодействия с обучающимися в синхронном и/или асинхронном режимах и работа с информационными образовательными ресурсами дистанционного обучения для управления учебным процессом» [1].

Успешность профессионального становления будущего учителя в условиях применения дистанционных технологий зависит от овладения способами и приёмами использования информационно-коммуникационных технологий в своей будущей деятельности, от условий применения дистанционных образовательных технологий в образовательном процессе. 


\section{РАЗВИТИЕ НАУКИ В ЭПОХУ ЦИФРОВИЗАЦИИ: ПРОБЛЕМЫ, ТЕНДЕНЦИИ, ПРОГНОЗЫ}

Объём информации растёт с каждым днём. А вот расширить границы урока для ученика невозможно. Приходится взрослым искать выход: это или кружки, или секции в системе дополнительного образования, или платные услуги - репетиторство.

Оснащение образовательных организаций техническим оборудованием на современном этапе позволяет без проблем увеличить или ускорить образовательный процесс обучающегося. Осуществить это возможно через обмен информацией посредством сети Интернет (работа с литературными источниками, разнообразные виды учебной деятельности, приобретение научных источников, диагностика, тестирования и пр.). Всё это проходит через дистанционное образование, которое не отменяет урочную традиционную систему, а дополняет её, делает более насыщенной.

Многим современным студентам и обучающимся школ нравится заниматься дистанционно, потому что экономит время, приходится учиться правильно его распределять, устанавливается индивидуальная скорость обучения, накапливается социальный опыт. В настоящее время в образовательном процессе присутствует целая система организации дистанционного обучения, иногда по нескольким направлениям деятельности сразу.

Самая интенсивная сторона системы дистанционного обучения - это обширные возможности для коммуникативного общения. Обучающиеся имеют возможность отправлять друг другу сообщения, передавать файлы разного размера. Они вступают в тесный контакт с преподавателем и сверстниками, могут работать индивидуально и в группе.

Помимо общения информационная система позволяет создавать файловые папки любого содержания, сохранять большой объём материала, синхронизировать фото и видео съёмки, находить изображения разных размеров и видов, идти на контакт с мессенджерами через голос, видео или текст - сообщения. Это виртуальное свободное пространство, которое можно использовать все 24 часа в сутки.

Разрешение о применении дистанционных образовательных технологий в учебном процессе прописано в документе «Информатизация образования» Национального приоритетного проекта «Образование» [3]. 


\section{РАЗВИТИЕ НАУКИ В ЭПОХУ ЦИФРОВИЗАЦИИ:

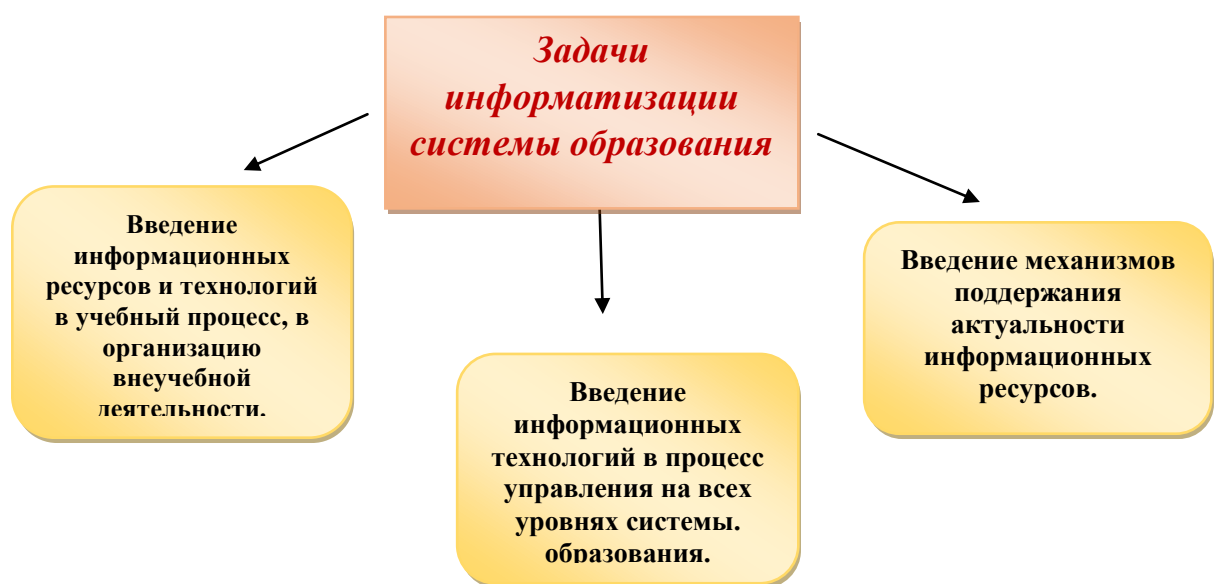

Рис. 1. Задачи информатизации системы образования

Процесс информатизации системы образования сегодня предполагает ряд задач, представленных в данном документе (рис. 1).

На сегодняшний день у каждого современного человека есть компьютер или сотовый телефон с доступом в Интернет, открытой мобильной связью. Он может в любом месте в любой час участвовать в образовательном процессе, однако дети не всегда могут сами планировать учебную деятельность, появляются проблемы с доступом к цифровым образовательным ресурсам. Следовательно, обучающийся должен обладать навыками самостоятельной организации труда и иметь в виду, что контроль чаще всего будет осуществляться в тестовой форме.

Информатизация образовательной системы включает в себя и совершенствование организации учебного процесса. Осуществляется данная работа через трансформацию методов и форм передачи информации, с целью активизации деятельности обучающихся, формирования их творческой активности. Всё это с использованием проекторов, экранов, компьютеров и другой электронной техники [15, с.57].

Однако, сейчас для молодёжи информационные технологии - это средство развлечения. Они используют их не для обучения и получения новых знаний. Для правильной установки обучения и корректировки имеющихся знаний им нужен компетентный педагог, который научит пользоваться данным мобильным оборудованием. То есть процесс информатизации в системе образования не может быть правильно организованным без участия взрослого, знающего все информационные процессы. Он должен уметь пользоваться 


\section{РАЗВИТИЕ НАУКИ В ЭПОХУ ЦИФРОВИЗАЦИИ: ПРОБЛЕМЫ, ТЕНДЕНЦИИ, ПРОГНОЗЫ}

информационными технологиями на уровне уверенного пользователя, быть грамотным, эрудированным специалистом.

Вот мы и пришли к тому, что должен уметь будущий педагог в условиях применения дистанционных технологий. Именно владение данными технологиями должно мотивировать студента на его дальнейшее профессиональное становление и образование.

Следовательно, при правильной организации использования дистанционных образовательных технологий можно добиться положительных результатов обучения. Для этого следует только разрешить проблемы организации учебного процесса и мотивировать будущих учителей на применение в своей работе информационно-коммуникационных технологий.

Профессиональная мотивация связана с мотивацией к успеху и увлеченностью своей профессией. По результатам исследования развития профессиональной мотивации будущих учителей в условиях применения дистанционных технологий потребности в достижении цели (Орлов Ю.М.) студентов, выявили, что 12\% имеют высокий уровень потребности в успехе. Данные представители характеризуются настойчивостью в достижении цели, неудовлетворенностью своей деятельностью, стремлением двигаться вперед, не стоят на месте. Они склонны к увлечению работой, отличаются отсутствием духа соперничества, желанием помочь другим в достижении цели. Их поддерживают недалеко ушедшие по баллам участники повышенного уровня еще $12 \%$. Средний уровень составил - 18 человек $(36 \%)$. Пониженный и низкий уровни составили 40\%. Эти участники эксперимента выделяются нежеланием работать, любят тянуть время, «тормозить» дела; отсутствием цели, доброжелательности, стремления помочь другим и самому себе.

По результатам диагностики уровня увлечённости работой педагогами системы образования («Утрехтская шкала увлеченности работой» У. Схауфели) увлечённость работой на высоком уровне у 20\% респондентов, умеренный уровень составил 64\% и низкий уровень наблюдается у $16 \%$.

Анализ проведенного исследования показал, что у будущих педагогов системы образования отмечаются невысокие уровни увлеченности работой и потребности в достижении целей, а значит, отсутствие профессиональной мотивации. Для мотивации профессионального становления будущего учителя в условиях применения дистанционного обучения могут быть использованы тренинги, направленные на конструктивное решение проблемных ситуаций, на 


\section{РАЗВИТИЕ НАУКИ В ЭПОХУ ЦИФРОВИЗАЦИИ: ПРОБЛЕМЫ, ТЕНДЕНЦИИ, ПРОГНОЗЫ}

мотивацию профессионального становления будущего учителя, повышение уровня увлеченности работой, стремления к достижению успеха, на развитие у педагога навыков рефлексии, умения анализировать и оценивать собственные действия, раскрытие своего собственного стиля, своего отношения к себе, утверждение собственного «Я».

Сегодняшний лозунг современного образования звучит так: «учить и учиться в среде XXI века». На смену обычным привычным педагогическим технологиям пришли информационные и дистанционные технологии, использование которых иногда не зависит от нас.

Представители социальной среды - педагоги и обучающиеся образовательных организаций - встречаются ежедневно с огромным потоком свежей информацией. Причём, использовать её полностью нет ни у кого возможностей.

Современная ситуация развития системы образования привнесла новейшую технологию в процесс обучения детей - это информатизация. Данный процесс тесно связан с развитием информационного общества, её доступностью, свободой, гласностью. По своей сути «информатизация образования» подразумевает обеспечение системы образования теорией и практикой внедрения новых информационных технологий, которые помогут педагогам в кратчайшие сроки реализовать цели обучения и воспитания подрастающего поколения.

Перечень мероприятий по информатизации образования включает в себя:

- программное снабжение учреждений образования средствами информационных технологий;

- открытие в каждом образовательном учреждении точек доступа к Интернет (локальное или высокоскоростное подключение сети);

- размещение информационных источников образовательного учреждения в сети Интернет;

- формирование информационной культуры у всех участников учебного процесса;

- организация профессионального непрерывного обучения педагогического состава каждого образовательного учреждения в области информационных технологий.

Дистанционные технологии делаются предопределяющим компонентом системы образования. Однако, при использовании в процессе обучения и 


\section{РАЗВИТИЕ НАУКИ В ЭПОХУ ЦИФРОВИЗАЦИИ:

воспитания электронных ресурсов следует придерживаться законодательных актов, которые регулируют использование данных методов работы. Каждый новый электронный ресурс должен соответствовать федеральному государственному образовательному стандарту системы образования. Доказано, что наибольший эффект электронные технологии привносят в систему работы в единстве с традиционной системой обучения.

Успешность профессионального становления будущего учителя зависит от овладения способами и приёмами использования информационнокоммуникационные технологии в своей будущей деятельности, от условий применения дистанционных образовательных технологий в образовательном процессе. Всё это опирается на технологический прогресс, реорганизацию всех сфер жизни человека, в том числе и системы образования.

Мотивационное развитие профессионального становления будущего учителя в условиях применения дистанционных технологий является одной из важнейших задач высшего учебного заведения. Информатизации образования в современном мире отводится существенная роль, поскольку именно данный процесс является «двигателем» будущего. Именно от данного процесса зависит успех качественного образования.

\section{Список литературы}

1. Федеральный закон от 29.12.2012 № 273-Ф3 (ред. от 08.12.2020) «Об образовании в Российской Федерации» (с изм. и доп., вступ. в силу с 01.01.2021) Ст. 16. Реализация образовательных программ с применением электронного обучения и дистанционных образовательных технологий http://www.consultant.ru/document/cons_doc_LAW_140174/9ab9b85e5291f25d698 6b5301ab79c23f0055ca4/

2. Приказ Минобрнауки РФ от 02.08.2005 г. № 218 «О временных требованиях, предъявляемых к образовательным учреждениям среднего, высшего и дополнительного профессионального образования при проведении лицензионной экспертизы и проверки их готовности к реализации образовательных программ с использованием в полном объеме дистанционных образовательных технологий» https://normativ.kontur.ru/document?moduleId= $1 \&$ documentId=83957

3. Приказ Минобрнауки РФ от 23.08.2017 № 816. «Об утверждении Порядка применения организациями, осуществляющими образовательную 


\section{РАЗВИТИЕ НАУКИ В ЭПОХУ ЦИФРОВИЗАЦИИ:

деятельность, электронного обучения, дистанционных образовательных технологий при реализации образовательных программ» https://base.garant.ru/ $71770012 /$

4. Письмо Минпросвещения России от 12.10.2020 № ГД-1736/03 «О рекомендациях по использованию информационных технологий» (вместе с Рекомендациями по использованию информационных технологий в образовательном процессе в условиях распространения новой коронавирусной инфекции в 2020/2021 учебном году) https://lyssch5.edusite.ru/DswMedia/ rekomendaciiiktdooktyabr-2020.pdf

5. Бакшаева, Н.А. Психология мотивации студентов: учебное пособие для вузов / Н.А. Бакшаева, А.А. Вербицкий. - 2-е изд., стер. - Москва: Издательство Юрайт, 2020. - 170 с.

6. Зеер, Э.Ф. Психология профессионального образования: учебник для академического бакалавриата / Э.Ф. Зеер. - 2-е изд., испр. и доп. - М.: Издательский центр «Юрайт», 2019 - 395 с.

7. Зверева, Ю.С. Информатизация образования / Ю.С. Зверева. - Текст: непосредственный // Молодой ученый. - 2016. - № 6.3 (110.3). - c. 23-26.

8. Зубанова, И.Н. Создание кейсов для дистанционного обучения [Электронный pecypc] / И.Н. Зубанова. - Режим доступа: http://www.proshkolu.ru/user/zuban59/file/1816412/

9. Климов, Е.А. Психология профессионального самоопределения: учебное пособие для студентов высш. учеб. заведений / Климов Е.А. - 4-е изд., стер. - М., Академия, 2016. - 304c. https://bookree.org/reader?file=591060

10. Монахов, Н.В. Дистанционное образование как социальное явление [Текст]: монография / Н.В. Монахов, Д.Н. Монахов. - Москва: МАКС Пресс, 2016. $-95 \mathrm{c}$.

11. Околелов, О. П. Дидактика дистанционного образования [Текст] / О.П. Околелов. - Москва: DirectMEDIA, 2015. - 98 c. https://books.google.ru/ books?id=crThAwAAQBAJ\&printsec $=$ frontcover\&hl=ru\&output=html_text

12. Основы профориентологии: учеб. пособие для студентов вузов / [С.И. Вершинин, М.С. Савина, Л.Ш. Махмудов, М.В. Борисова]. - М.: Академия, 2019 - 174c.

13. Панина, С.В. Самоопределение и профессиональная ориентация учащихся: учебник и практикум для академического бакалавриата / С.В. Панина, Т.А. Макаренко. - 3-е изд., перераб. и доп. - М.: Издательство Юрайт, $2017-312$ с. 


\section{РАЗВИТИЕ НАУКИ В ЭПОХУ ЦИФРОВИЗАЦИИ:

14. Пастернак, Н.А. Психология образования: учебник и практикум для вузов / Н.А. Пастернак, А.Г. Асмолов; под редакцией А.Г. Асмолова. - 2-е изд., перераб. и доп. - Москва: Издательство Юрайт, 2020. - 213 с.

15. Пащенко, О.И. Информатизация образовательного процесса в начальной школе: учебное пособие. - Нижневартовск: Изд-во Нижневарт. гос. ун-та, 2014. - 257 с.

16. Педагогические технологии дистанционного обучения: учебное пособие для вузов / Е.С. Полат [и др.]; под редакцией Е.С. Полат. - 3-е изд. Москва: Издательство Юрайт, 2020. - 392 с.

17. Полат, Е.С. Современные педагогические и информационные технологии в системе образования: учеб. пособие для студ. высш. пед. учебн. заведений / Е.С. Полат, М.Ю. Бухаркина. - М.: Академия, 2016. - 368c. https://www.academiamoscow.ru/ftp_share/_books/fragments/fragment_19666.pdf

18. Практическая психология образования; Учебное пособие 5-е изд. / Под редакцией И.В. Дубровиной - СПб.: Питер, 2017. - 592 с https://www.mnogobook.ru/nauka_obrazovanie/psihologiya/158391/fulltext.htm

19. Пряжников, Н.С. Профессиональное самоопределение: теория и практика: учеб. пособие для студентов вузов / Н.С. Пряжников. - М.: Академия, 2018 - 318c. https://docviewer.yandex.ru/view/981112432/

20. Психология труда: учебник и практикум для вузов / С.Ю. Манухина [и др.]; под общей редакцией С.Ю. Манухиной. - Москва: Издательство Юрайт, 2020. - 485 c.

21. Свиридова, Т.А. Мотивация персонала как важнейший фактор повышения конкурентоспособности организации / Т.А. Свиридова, А.С. Вобликова // Научно-методический электронный журнал «Концепт». 2016. - т. 2. - c. 536-540. http://e-koncept.ru/2016/46126.htm.

22. Теория и практика дистанционного обучения: учебное пособие для вузов / Е.С. Полат [и др.]; под редакцией Е.С. Полат. - 2-е изд., перераб. и доп. - Москва: Издательство Юрайт, 2020. - 434 с. - (Высшее образование). ISBN 978-5-534-13159-8. - Текст: электронный // ЭБС Юрайт [сайт]. URL: https://urait.ru/bcode/449342 .

23. Шарипов, Ф.В. Педагогические технологии дистанционного обучения: учебное пособие / Ф.В. Шарипов, В.Д. Ушаков. - Москва: Университетская книга, 2020. - 304 с. 


\section{ГЛАВА V.}

\section{ОСНОВНЫЕ НАПРАВЛЕНИЯ РАЗВИТИЯ КОГНИТИВНОЙ ЛИНГВИСТИКИ (НА МАТЕРИАЛЕ МОНОГРАФИИ ВИВИАНА ЭВАНСА «COGNITIVE LINGUISTICS. A COMPLETE GUIDE» SECOND EDITION. - EDINBURGH: EDINBURGH UNIVERSITY PRESS, 2019. - 858 P.)}

К.М. Денисов к.ф.н., доцент кафедра Иностранных языков №2

Е.И. Лобанова к.с.н., доцент кафедры Иностранных языков № 2 Российский экономический университет им. Г.В. Плеханова, г. Москва

Аннотация: Данное исследование рассматривает и обобщает научный труд известного британского ученого Вивиана Эванса, который посвящается изучению когнитивной лингвистики. Основная цель монографии заключается в построении целостного взаимодействия сознания и языка, механизмов созидания языковых конструктов. В данной статье анализируются церебральные процессы мыслительного, эмотивного и модально-волевого познания окружающего мира и адаптации к нему. Все это рассматривается сквозь призму эволюции языка как постоянно обретаемого опыта отдельным индивидом и качеством в целом.

Ключевые слова: языковой конструкт, принципы генерализации, герменевтика, когнитивная лингвистика, концепты, перцепты.

\section{THE MAIN DIRECTIONS OF THE DEVELOPMENT OF COGNITIVE LINGUISTICS (BASED ON THE MONOGRAPH BY VIVIAN EVANS «COGNITIVE LINGUISTICS. A COMPLETE GUIDE» SECOND EDITION. - EDINBURGH: EDINBURGH UNIVERSITY} PRESS, 2019. - 858 P.)

Konctantin Mihailovich Denisov Lobanova Evdokiya Ivanovana

Abstract: This study examines and summarizes the scientific work of the famous British scientist Vivian Evans, which is devoted to the study of cognitive 


\section{РАЗВИТИЕ НАУКИ В ЭПОХУ ЦИФРОВИЗАЦИИ:

linguistics. The main purpose of the monography is to build a holistic interaction of consciousness and language, the mechanisms of creation of language constructs. This article analyzes the cerebral processes of mental, emotional, and moral-volitional cognition of the surrounding world and adaptation to it. All this is viewed through the prism of the evolution of language as a constantly acquired experience of the individual and the quality as a whole.

Key words: language construct, generalization principles, hermeneutics, cognitive linguistics, concepts, percepts.

Рассматриваемая монография является обобщающим трудом известного британского ученого Вивиана Эванса и основана на более раннем труде Cognitive Linguistics: An Introduction (Evans and Green, 2006). Профессор Эванс является международно-признанным экспертом по вопросам языка и цифровой коммуникации. Он получил докторскую степень по лингвистике при Джоржтаунском университете в г. Вашингтоне (США) в 2000 году, преподавал в ряде британских университетов (Суссекс, Брайтон и Бангор). Эванс является автором 14 монографий, среди которых наиболее известны: The Emoji Code: The Linguistics Behind Smiley Faces and Scaredy Cats (2017); The Crucible of Language: How Language and Mind Create Meaning (2015); and The Language Myth: Why Language is Not an Instinct (2014).

Профессор Эванс является приверженцем теории Семантического docmyna (Access Semantics) или теории лексических концептов и когнитивных моделей (ЛККМ), рассматривающей язык в качестве конструктора отраженных концептуальных систем (время, пространство и пр.).

Масштаб монографии впечатляет: текст книги содержит предисловие, пять массивных разделов, расположившихся на 813 страницах текста, обширную библиографию, включающую 720 источников, постраничный индекс использования 878 базовых терминов, 213 рисунков, графов и схем, а также 98 таблиц.

Основной пафос работы, на наш взгляд, заключается в попытке решения стратегической задачи - построении комплексной картины взаимодействия сознания и языка, раскрытии мотивационных механизмов созидания языковых конструктов, непосредственно отражающих церебральные процессы мыслительного, эмотивного и модально-волевого познания окружающего мира и адаптации к нему. Все это рассматривается сквозь призму эволюции языка 


\section{РАЗВИТИЕ НАУКИ В ЭПОХУ ЦИФРОВИЗАЦИИ: ПРОБЛЕМЫ, ТЕНДЕНЦИИ, ПРОГНОЗЫ}

как постоянно обретаемого опыта отдельным индивидом и человечеством в целом.

В предисловии к данному, второму изданию книги автор представляет ее как наиболее полный экскурс в историю и современность когнитивной лингвистики - сложившейся, самостоятельной отрасли западного и мирового языкознания. Двумя базовыми установками этого учения В. Эванс считает принципы генерализациии (Generalisation Commitment) и когнитивизма (Cognitive Commitment). Они предопределяют теорию и методологию исследования языковой концептуальной структуры, семантики и прагматики, а также подчеркивают связь когнитивной отрасли языкознания со смежными научными дисциплинами, направленными на изучение мозговой деятельности и сознания носителей языка, их социального поведения.

Автор анализирует основополагающие принципы и правила когнитивной лингвистики в их приложении к изучению таких разделов как семантика, прагматика, фонология и грамматика. Известная часть книги посвящена проблемам герменевтики и невербальной коммуникации. Основной своей задачей профессор Эванс считает создание подробного «путеводителя», целостной и динамичной панорамы функционирования отрасли когнитивной лингвистики на примерах применения современных принципов и методик экспериентализма.

В связи с этим, каждая из пяти частей книги представляет собой тематическую группировку языковых примеров, используемых для демонстрации дескриптивных возможностей гносеологического арсенала когнитивного языкознания и соответствующих концептуальных обобщений.

Часть I «Отрасль когнитивной лингвистики» отражает идеологию данного направления и содержит 7 глав, каждая из которых является иллюстрацией применения основных принципов и правил когнитивистики, а также противопоставляет когнитивную лингвистику так называемой формальной лингвистике, представленной, прежде всего, постулатами трансформациионной грамматики.

Глава 1 «Что изучают когнитивные лингвисты?» является идеологической интродукцией когнитивистики и рассматривает объект и предмет ее исследования. Объектом изучения являются все языковые единицы от морфемы до текста, функционирующие в экспериенталистских фреймах, то есть интерактивных условиях реализации концептуальной структуры нашего 


\section{РАЗВИТИЕ НАУКИ В ЭПОХУ ЦИФРОВИЗАЦИИ: ПРОБЛЕМЫ, ТЕНДЕНЦИИ, ПРОГНОЗЫ}

сознания. Из анализа коммуникативного опыта мы черпаем знания о системности, структуре и функциях языка. Язык кодирует и воплощает наши мысли посредством символов, представляющих собой формально-смысловые пары или символические блоки, которые служат репрезентантами концептов.

Концепты являются производными от перцептов - результатов обработки фактов чувственного восприятия. Значения, кодируемые лингвистическими символами, относятся к проектируемой реальности, определяемой как мыслимое представление о реальности, конструируемой нашим сознанием. Поскольку диапазон концептуализаций безграничен, язык предоставляет лишь конструкты для их моделирования.

Символические блоки систематизируются в концептуальные домены, содержанием которых являются идеи и разновидности когнитивного опыта. Таким образом, утверждает автор, языковые структуры предстают как мотивированные и оформленные «рефлексы познания».

Языковые формы являются когнитивными репрезентантами двух основных подсистем языка - лексической и грамматической. Члены первой подсистемы открытого класса воплощают буквальное значение и выполняют содержательную функцию. Элементы второй системы закрытого класса несут идиоматическое значение, выполняя структурирующую функцию. Взаимодействие элементов обоих классов порождает схематическое значение языкового фрейма. Декодирование и дескрипция данных значений, их системная связь с процессами познания и таксономия являются предметом исследования когнитивных лингвистов.

Глава 2 «Ключевые установки и методы исследования» содержит изложение базовых установок: генерализации и когнитивизма. Особый интерес для специалистов представляет описание методов научного исследования: интроспективного, аудио-визуального, корпусного, бихевиористского, нейронаучного.

Глава 3 «Основные положения опыта I: пространство» представляет проекцию частного исследования категории «пространство», предпринятого автором. Восприятие данной категории разделено на фазы: ощущение, перцептивная организация/идентификация и распознавание. Ощущения преобразуются в нейронные коды, распознаваемые мозгом.

Распознавание идет по модальным системам: визуальной, вестибулярной, аудитивной и гаптической. Здесь впервые в книге вводится рекуррентное 


\section{РАЗВИТИЕ НАУКИ В ЭПОХУ ЦИФРОВИЗАЦИИ: ПРОБЛЕМЫ, ТЕНДЕНЦИИ, ПРОГНОЗЫ}

понятие полимодальности человеческого восприятия. Фаза перцептивной организации состоит из процесса преобразования чувственной информации в единый объект сознания - перцепт. Предварительно сформированный концепт распознает, идентифицирует и классифицирует перцепт как категорию, которая в результате обработки встраивается в концептуальную систему. Автономность концепта обеспечивается применением гештальт-принципа, состоящего в мысленном перемещении образа предмета с заднего плана на переднее поле (в светлую точку) сознания.

В. Эванс уделяет большое внимание пространственных схемам на примере их составных конструктов (элементов закрытых классов слов), в данном случае английских предлогов. Данное исследование, как впрочем, и многие другие примеры частных исследований, приведенных в книге, ценны для нас в качестве опыта глубинной интерпретации функционирования морфосинтаксических элементов носителем языка.

Пространственные схемы анализируются в терминах их пространственногеометрических компонентов, свойств этих компонентов и отношений между ними. Автор анализирует фреймы пространственной референции (ФПР) системы координат, включающие фигуру, объект и начальную точку референции, а также специфику кроссязыковых репрезентаций категории «пространство».

Глава 4 «Основные положения опыта I: время» содержит таксономию ФВР - фреймов временной референции, как на примере английского языка, так и языков юго-восточной Азии. Рассматривается матрица концепта «время» в прямом (темпоральном) аспекте лексического значения слова и в ракурсе теории концептуальной метафоры. Анализируются параметрические концепты направленности, протяженности, последовательности, мимолетности. Инновационным представляется взгляд автора на видовременную семантику глагольных форм, который получает развитие в последующих главах монографии.

Глава 5 «Практика языка I: знание о языке» начинает полемику с менталистской концепцией языковой компетенции. Приводятся три составляющие узуального базиса языка, принятого в когнитивной лингвистике: a). учение о высказывании, б). учение об узусе как источнике знания о языке и в). учение об интерактивной природе языковой практики, г). учение о контексте и д). учение об относительной частотности языковых единиц как основной характеристике природы языковых систем. 


\section{РАЗВИТИЕ НАУКИ В ЭПОХУ ЦИФРОВИЗАЦИИ: ПРОБЛЕМЫ, ТЕНДЕНЦИИ, ПРОГНОЗЫ}

Названные аспекты рассматриваются автором в разрезе узуальной модели - когнитивной грамматики Рональда Ла́нгакера. Эта модель противопоставляется модели трансформационной грамматики Наума Хомского. Модель Ла́нгакера определяет лингвистические единицы как символические блоки, напрямую выводимые из языковой практики посредством процесса абстрагирования, результатом которого является создание схем.

Глава 6 «Практика языка II: усвоение языка и языковые изменения» представляет собой анализ двух алгоритмов: алгоритма языковой изменчивости (теория выбора высказываний Крофта) и алгоритма усвоения языка (психолингвистическая теория Томаселло). Автор демонстрирует процесс форсайтного развития языковых форм через возможность альтернативного воспроизведения, закрепления и отбора формально-смысловых комплексов. Это, по его мнению, приводит к принятию новых языковых конвенций и, соответственно, стратегическим изменениям в языке.

Далее, профессор Эванс, вслед за Майклом Томаселло, утверждает, что усвоение языка уже в раннем возрасте происходит не на основании правил (rules), а на основании непосредственных данностей (items). Данный узуальный навык формирует у индивида объединенные фреймы внимания (ОФВ), облегчающие имитацию языкового поведения, что в свою очередь становится устойчивой формой культурного познания, которое в своей основе носит характер символического конструирования.

Глава 7 «Ключевые дискуссионные вопросы языкознания: формальная лингвистика в противовес когнитивной лингвистике» завершает первую часть книги. В ней автор приводит подробную дискуссию двух ведущих западных школ языкознания.

Согласно постулатам формальной лингвистики, представленной в книге работами Наума Хомского и Джерри Фодора, язык, как некая генетическая мутация появляется у человека сравнительно недавно в виде качественного скачка (сальтации) и коренится в формальных моделях. Язык скорее необходим как универсальный инструмент для выражения мысли, а не для коммуникации. При этом подчеркивается жесткая модульность сознания.

Когнитивная лингвистика, в противовес сказанному, постулирует тезис экспериентального реализма, согласно которому не существует врожденной биологической предопределенности языка. Язык происходит из 


\section{РАЗВИТИЕ НАУКИ В ЭПОХУ ЦИФРОВИЗАЦИИ: ПРОБЛЕМЫ, ТЕНДЕНЦИИ, ПРОГНОЗЫ}

приобретенного опыта как межотраслевая сущность познания, имеющая не скачкообразную, а длительную градуально-эволюционную историю. Язык, формируемый и очерченный общностью воплощенного познания, - это особая нища общения, свойственная человеку как биокультурному виду. Языковая коммуникация является источником универсального концептуального пространства, в котором языки располагаются в виде специфических семантических навигационных карт, иногда сходящихся в общих точках. Актуальной, в этой связи является переосмысленная когнитивными лингвистами теория языкового релятивизма Сэпира-Уорфа, согласно которой язык приводит к когнитивной реструктуризации, то есть язык влияет на мысль и сознание в целом.

Часть II «Концептуальная структура» раскрывает представление автора о концептуальной структуре как субстрате, помещенном в человеческую концептуальную систему, обслуживающую язык и мышление. Язык отражает природу, структуру и организацию мысли, раскрывая окно в мир человеческого сознания и воплощенного опыта.

Две базовые установки когнитивной лингвистики включают два главных гносеологических принципа, которые способствуют осмыслению концептуальной структуры. Первый принцип - это тезис о воплощенности концептуальной структуры, известный также под названием «тезис воплощенного сознания». Второй принцип состоит в том, что семантическая структура (значения, кодируемые языком) отражает концептуальную структуру. Иллюстративным материалом применения этих принципов служат главы, посвященные таким явлениям, как: образные схемы, концептуальные метафоры, категоризация и метонимия.

Часть III «Семантическая структура» постулирует энциклопедический характер семантической структуры. Энциклопедический взгляд на семантику способствует, по мнению автора, созданию симуляций или динамических моделей сознания, активизирующих процессы мультимодального воплощенного опыта, опосредованного языком. На различных примерах реконструкции и анализа значения языковых единиц профессор Эванс демонстрирует явления энциклопедической семантики, ментального пространства, сложных концептуальных слияний, а также рассматривает частные вопросы формирования лексического и композиционнограмматического значения. 


\section{РАЗВИТИЕ НАУКИ В ЭПОХУ ЦИФРОВИЗАЦИИ: ПРОБЛЕМЫ, ТЕНДЕНЦИИ, ПРОГНОЗЫ}

Часть IV «Грамматика» затрагивает проблему природы грамматических явлений с точки зрения когнитивного лингвиста. Традиционно выделяемые языковые формы (фонологические, морфологические и синтаксические) сопоставляются со значением в контексте их символической природы. Подробный экскурс в область происхождения, историю и современное состояние языковых единиц, проведенный автором, позволяет нам увидеть инновационную трактовку лексико-грамматических и морфосинтаксических явлений, основанную на когнитивных принципах. Эта трактовка отличается от воззрений представителей традиционной, структуралистской и трансформационной грамматик.

Прежде всего, это касается грамматических явлений, категорий и субкатегорий (имманентная грамматикализации лексико-грамматического континуума, темпоральные и атемпоральные отношения, мотивационные созначения, модель акциональных цепочек, атрибутивная версия вербалий, эпистемология видо-временных отношений, валентно-семантические домены, предикативные схемы и многое другое).

Привлекает внимание статья 27, посвященная эволюции взаимодействия синхронии и диахронии в процессе более детального и глубинного анализа грамматических явлений языка с точки зрения таких лингвокогнитивных теорий и таких подходов как: идея метафорического расширения, учение об уровневой полисемии, теорий субъектификационного конструирования, прагматической инференции и кодификации и других.

Часть V «Применение и распространение когнитивного языкознания» посвящена освещению процесса проникновения когнитивной теории и методологии в такие сферы познания как социальное поведение, дискурсивная практика, языковая вариативность и диалектология, мультимодальная коммуникация, невевербальное коммуникация, текстология и герменевтика, когнитивная поэтика. В. Эвансу безусловно удается в отдельных главах, посвященных каждой из названных тем соблюсти баланс между теоретическими постулатами и практическим анализом явлений в русле избранных методик.

В целом, книга напоминает построение рондо - в каждой из глав автор возвращается к принципам генерализации и когнитивизма, основным правилам и методикам, применяя их при конструировании конкретных процедур, моделей и схем анализа различных явлений и параметров дискурса. В ткань 


\section{РАЗВИТИЕ НАУКИ В ЭПОХУ ЦИФРОВИЗАЦИИ:

работы вплетены как рассмотрение достижений его предшественников, так и результаты собственных исследований В. Эванса в русле когнитивной лингвистики, проводимых автором на протяжении более двадцати последних лет. Они включают: раскрытие смысла основополагающих доменов пространства и времени в структуре человеческого опыта (Главы 3 и 4), вклад в развитие подходов когнитивной лингвистики к исследованию лексической семантики (Глава 17) и композиционной семантики слова (Глава 18$).$

Наряду с бесспорным теоретическим, исследовательским и справочноинформационным значением книги следует отметить ее образовательную ценность. Разделы книги, посвященные анализу лингвистических явлений, снабжены вопросами для обсуждения и закрепления прочитанного. Использование этих материалов в курсах лекций по лексикологии, семасиологии, грамматики, фонологии, психолингвистике, социолингвистике и невербальной коммуникации может быть расширено с помощью образовательной платформы университета Эдинбурга (edinburghuniversitypress.com/cognitivelinguistics), содержащей большое количество упражнений, которые можно загрузить он-лайн для работы на тематических семинарах и практикумах.

Обширная терминология, накопленная за более чем полувековую историю развития когнитивной лингвистики, представлена как в тексте монографии, так и в сопряженном с книгой алфавитном глоссарии - Glossary of Cognitive Linguistics (Evans 2007).

\section{Список литературы}

1. Croft, W. and D.A. Cruse (2004), Cognitive Linguistics, Cambridge - New York: Cambridge University Press. [A textbook with a very strong focus on the construction grammar ap-proach.]

2. Geeraerts, D. and H. Cuyckens, eds. (2007), The Oxford Handbook of Cognitive Linguistics, Oxford etc.: Oxford University Press. [comprehensive overview of cognitive linguistics in 50 chapters. Useful as a reference work and as a source of detailed accounts of selected areas.]

3. Kövecses, Z. (2002), Metaphor. A practical introduction, Oxford: Oxford University Press. [Accessible and richly illustrated introduction to the conceptual theory of metaphor and me-tonymy; includes a chapter on conceptual blending] 
4. Langacker, R. W. (2008), Cognitive grammar. A basic introduction, Oxford: Oxford Univer-sity Press. [Labelled a basic introduction, this textbook gives a very good state-of-the-art account of Langacker's cognitive grammar but is still quite demanding.]

5. Ungerer, F. and H.-J. Schmid (2006), An introduction to cognitive linguistics, 2nd ed., Har-low: Pearson Longman. [Accessible introduction covering all major areas of cognitive 1 


\title{
ГЛАВА VI.
}

\section{УДК 331.101.6}

\section{СТАТИСТИЧЕСКИЕ МЕТОДЫ В НОРМИРОВАНИИ ЧИСЛЕННОСТИ ПЕРСОНАЛА}

\begin{abstract}
Кирьянова Галина Геннадьевна
преподаватель экономики

Уральский Государственный железнодорожный университет путей сообщения

Колледж железнодорожного транспорта (КЖТ УрГУПС)

г. Екатеринбург
\end{abstract}

Аннотация: В статье рассматриваются вопросы планирования уровня производительности труда с применением опытно статистического метода нормирования труда при расчете численности персонала. Приведены примеры прогнозирования численности на основе статистических данных и экономического анализа.

Ключевые слова: экономический анализ, математические методы, нормирование труда, расчет численности персонала, производительность труда.

\section{STATISTICAL METHODS IN RATING STAFF}

\section{Kiryanova Galina Gennadievna}

В кризисных экономических условиях внутренняя среда любого предприятия адаптируется к постоянным изменениям внешней среды. Прежде всего неравномерность объемов работ требует серьезного отношения к производственным или бюджетным затратам. В нестабильной экономической ситуации появляется необходимость гибкого управления и мгновенной реакции на изменения ситуации. Предприятия ищут новые методы работы с расходами, в том числе с расходами на персонал. Вопросы определения действительной трудоемкость работ, а так же определение фактических трудозатрат 


\section{РАЗВИТИЕ НАУКИ В ЭПОХУ ЦИФРОВИЗАЦИИ: ПРОБЛЕМЫ, ТЕНДЕНЦИИ, ПРОГНОЗЫ}

дистанционных работников выходят на первый план. Рынок предопределяет важность установления обоснованных трудовых затрат при определении цены на продукцию и цены на рабочую силу.

Экономический анализ, как инструмент управления финансовохозяйственной деятельности предприятия исторически использовал методы нормирование труда для изучения эффективности использования трудовых ресурсов. С переходом на цифровую экономику нормирование становится

В кризисных экономических условиях внутренняя среда любого предприятия адаптируется к постоянным изменениям внешней среды. Прежде всего неравномерность объемов работ требует серьезного отношения к производственным или бюджетным затратам. В нестабильной экономической ситуации появляется необходимость гибкого управления и мгновенной реакции на изменения ситуации. Предприятия ищут новые методы работы с расходами, в том числе с расходами на персонал. Вопросы определения действительной трудоемкость работ, а так же определение фактических трудозатрат дистанционных работников выходят на первый план. Рынок предопределяет важность установления обоснованных трудовых затрат при определении цены на продукцию и цены на рабочую силу.

Экономический анализ, как инструмент управления финансовохозяйственной деятельности предприятия исторически использовал методы нормирование труда для изучения эффективности использования трудовых ресурсов. С переходом на цифровую экономику нормирование становится инструментом фиксирования конкретных достижений в производственном процессе. Это значит, что производительность труда становится одним из ключевых показателей в кризисные периоды экономического развития. По общему мнению, резервы роста производительности труда заключаются именно в эффективном использовании рабочего времени. Время, как известно, универсальный измеритель. Другие факторы не исключаются из анализа, используется факторное нормирование, методы которого основываются на изучении влияния нескольких производственных параметров на общий результат производительности. Современные компьютерные программы дают возможность многое подвергать расчетам. Результаты, процессы, трудозатраты, расходы отражаются в статистике предприятия. Значит, «многофакторный» подход к изучению и анализу производительности труда возможен. 


\section{РАЗВИТИЕ НАУКИ В ЭПОХУ ЦИФРОВИЗАЦИИ: ПРОБЛЕМЫ, ТЕНДЕНЦИИ, ПРОГНОЗЫ}

Классические методы нормирования всегда считались трудоемкими, малопонятными. Нормирование не популярно в современной управленческой среде, в связи с тем, что советская система ведения хозяйства предполагала централизованное нормирование, то есть работали специальные институты. Технически обоснованные нормы разрабатывались на уровне государства, а местные производственные условия часто учитывались лишь через систему специальных коэффициентов. В настоящее время каждое предприятие столкнулось с тем, что нормы трудозатрат на какие-либо виды работ устарели, либо отсутствуют вовсе. Предприятия самостоятельно выстраивают систему нормирования, то есть пользуются местными нормами труда. На этом уровне фиксирование трудозатрат производится благодаря табельному учету и учету выработки. Если статистика отсутствует в достаточном объеме, то расчеты базируются на субъективных оценках, а это уже признаки опытностатистического метода нормирования. Информация в нашем случае источник и проблема во всех сферах расчета.

Руководителю предприятия нужно понимать, что ни один метод не дает результат за один день. Необходимо определенное время для получения устойчивого результата.

Целью настоящего исследования стало составление краткосрочного прогноза необходимой численности персонала при решении вопросов оптимизации трудовых затрат в резко изменяющихся внешних условиях рынка.

При решении практических задач по снижению численности персонала одноразовые мероприятия не дают устойчивого результата. В основном, при решении краткосрочных задач, все решается переводом работников на неполное рабочее время. Эти действия тоже требуют несложного расчета и прогноза по трудозатратам. При временном отсутствии штатного работника или на момент подбора персонала часто используется совмещение и внутреннее совместительство. При анализе трудовых показателей или при определении трудозатрат часто не учитываются такие важные организационные моменты выполнения работы. При разработке долгосрочных программ используются реорганизационные мероприятия, в том числе и вывод персонала на аутсорсинг и аустафинг. Однако, по различным причинам, аутсорсинг не всегда дает ожидаемый результат по снижению себестоимости. Структура затрат изменяется, а себестоимость не имеет ожидаемого уровня снижения. Иногда при составлении плана по труду, или определения конкурентной 


\section{РАЗВИТИЕ НАУКИ В ЭПОХУ ЦИФРОВИЗАЦИИ: ПРОБЛЕМЫ, ТЕНДЕНЦИИ, ПРОГНОЗЫ}

калькуляции(цены) наибольшую реальную и быструю пользу для координации расчетов может принести обмен опытом между предприятиями. (бренчмаркинг), то есть свой штат сравнивают с численностью персонала аналогичных компаний и «подгоняют» под такие величины собственный штат.

Ни один из методов прогнозирования величины численности персонала не является универсальным для всех ситуаций. При выборе метода планирования (моделирования, прогнозирования) необходимо учитывать ряд факторов. Два наиболее важных фактора - это объем информации и точность. Чем выше необходимая точность прогноза, тем больше объем информации требуется. Еще можно утверждать, что нельзя обеспечить точность прогноза без затрат времени на сбор материала, времени на глубокий анализ отчетных данных, то есть необходима система информации, структурированная статистика. Статистика численности персонала базируется на таких количественных показателях, как списочная численность, среднесписочная численность, явочная и нормативная (необходимая) численность. Сведения обычно группируются на плановые, фактические и данные базового периода. Все расчеты этих показателей базируются на использовании фонда рабочего времени. Повторюсь, что рабочее время является универсальным показателем и легко отцифровывается. Качественными показателями, характеризующими внутренние состояние персонала на предприятиях, являются: категории, квалификация, стаж работы, возраст, пол, производительность, формы оплаты, формы организации труда и др.

Для определения необходимой численности персонала различных групп и категорий используют несколько методов, но условно их можно разделить на три группы. Первая группа - по трудоемкости. Применяется во всех случаях, когда имеются нормы времени, нормы выработки, нормы трудоемкости.

Например, для основных рабочих, имеющих объемные показатели (например, сдельщики):

$$
\mathrm{U}_{\mathrm{o}}=\frac{\mathrm{Q}}{\mathrm{H}_{\mathrm{B}} * \mathrm{~F}}
$$

где Q - объем продукции (шт.);

$\mathrm{H}_{\text {в }}$ - норма выработки (шт. в час);

$\mathrm{F}$ - нормативный фонд рабочего времени одного работника (чел.час.);

$\left(\mathrm{H}_{\mathrm{B}} * \mathrm{~F}\right)$ - норма выработки на одного работника.

Численность персонала по общей трудоемкости в периоде (месяц, год): 


$$
\mathrm{Y}=\frac{\mathrm{To}}{\mathrm{F}}
$$

Где Т - общая трудоемкость процесса (трудовой функции) в периоде, чел.час;

F - нормативный фонд рабочего времени одного работника в периоде, час.

Вторая группа - по рабочим местам. Применяется на рабочих местах персонала с повременной оплатой труда (повременщиков), а так же для вспомогательных служб. По рабочим местам определяется численность повременщиков, когда нормирование отсутствует или затруднено, а так же когда продолжительность рабочего времен задается функцией или клиентом.

Например, расчет численности по рабочему месту

$$
\mathrm{Y}=\left(\mathrm{Ч}_{\mathrm{нор}} * \mathrm{~h} * \mathrm{M}\right) * \frac{\mathrm{К}}{N},
$$

где $Ч_{\text {нор }}$ - численность работников, необходимая для обслуживания одного рабочего места в смену;

$\mathrm{h}$ - время обслуживания в сутки(час.);

М -число суток работы в плановой периоде;

Кз - коэффициент замещения, \% ;

$\mathrm{N}$ - норма рабочего времени на одного работника за рассматриваемый период (чел.час) [1, с. 114].

Третья группа - по технологии. Применяется в случаях, когда количество работников определено и зафиксировано технологическим процессом, при наличии норм обслуживания, по нормам управляемости и т.д.

Bсе три группы методов мы должны учитывать при построении математической модели прогнозирования.

Проектирование организации труда, проектирование численности может основываться на количественной оценке рабочего времени, величины трудозатрат, структуры норм, удельному весу оперативного времени, потерь рабочего времени и величины времени не рабочего: отсутствия, отдых, простои, паузы и др. Предполагается построение математической модели процесса труда с описанием взаимосвязей без проведения непосредственного наблюдения на рабочем месте: фотографии рабочего дня, хронометража оперативного времени и т.д. Необходимо построить математическую модель, то есть зафиксировать ключевые или основные характеристики персонала для 


\section{РАЗВИТИЕ НАУКИ В ЭПОХУ ЦИФРОВИЗАЦИИ: ПРОБЛЕМЫ, ТЕНДЕНЦИИ, ПРОГНОЗЫ}

использования их при анализе результативности, а так же для прогнозирования величины необходимой численности. Все модели трудовых процессов имеют вид уравнения, в котором результат (трудовой процесс) есть функция множества переменных, определяющих содержание, то есть являются многофакторными моделями. Общий вид формул норматива численности работников по трудовым функциям (функциям управления) или факторам процесса:

$$
\mathrm{H}=\mathrm{ax}_{1}^{\mathrm{a} 1} \mathrm{ax}_{2}^{\mathrm{a} 2} \ldots \ldots \mathrm{ax}_{\mathrm{p}}^{\mathrm{ap}} \text { (не линейная зависимость) }
$$

$\mathrm{H}=\mathrm{a}+\mathrm{a}_{1} \mathrm{X}_{1}+\mathrm{a}_{2} \mathrm{X}_{2 \ldots} \ldots \mathrm{A}_{\mathrm{p}} \mathrm{X}_{\mathrm{p}}$ (линейная многофакторная зависимость),

где а - постоянный коэффициент уравнения;

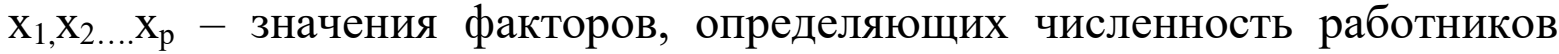
соответствующий функций или процессов;

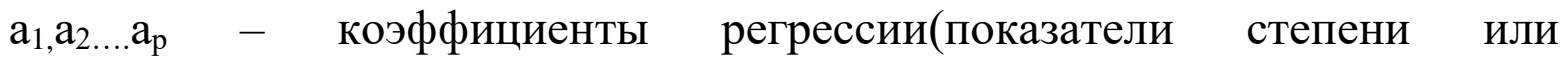
коэффициенты при факторах), характеризующие влияние соответствующего фактора на численность [2, с. 246].

Остановимся на том, что основной информацией для выбора метода расчета численности является трудоемкость процессов (продукта, услуги).

Часто сравнение фактических трудозатрат проводится с трудозатратами технически обоснованных норм. Но сравнение требуется не только на уровне оперативного времени, этому подлежат все организационно-производственные условия и особенности самого предприятия. Для такой работы нужна информация не только по оперативному времени, но и по огромному кругу вопросов, что является затратным, а порой невозможным из-за отсутствия информации. Но на уровне одного предприятия или холдинга такие методы имеют неоценимое значение как в краткосрочном, так и в стратегическом планировании.

Расчет трудоемкости по экономико-математическим моделям на основании многофакторных моделей, учитывающих влияние основных факторов на изменение затрат труда, проводится применительно в каждой группе работников, рабочего места или оборудования.

Например:

графоаналитический - рекомендуется использовать при разработке нормативов вспомогательного времени, времени на выполнение ручных работ и 


\section{РАЗВИТИЕ НАУКИ В ЭПОХУ ЦИФРОВИЗАЦИИ: ПРОБЛЕМЫ, ТЕНДЕНЦИИ, ПРОГНОЗЫ}

механизированных ручных работ при небольшом количестве влияющих факторов (до трех).

- методы теории ожидания (система массового обслуживания CMO)используется при изучении процессов вероятностного характера в условиях обслуживания автоматизированного производства, многостаночной работы, бригад ремонтников и др.;

- метод наименьших квадратов - применяется при обработке результатов большого количества наблюдений (или результатов эксперимента), предполагает построение нормативной линии и вывод эмпирической формулы;

- метод теории вероятности при определении численно персонала, выполняющего срочный ремонт и на аварийных работах.

- корреляционно-регрессивный анализ- применяется при количестве влияющих факторов не более 5 [3, с. 144].

Классификация трудоемкостей позволяет прогнозировать величину численности предприятия в нескольких измерениях одновременно. Например, построение информационных таблиц возможно по следующим параметрам в зависимости от цели, места периода. и назначения:

- по объекту исчисления - трудоемкость операции, изделия и т.д.;

- по месту формирования - цеховая, бригадная, отраслевая и т.д.

- по времени действия - отчетная, базовая, плановая, текущая;

По назначению трудоемкостей можно сгруппировать в следующем порядке:

- лимитная (верхний предел предельно допустимой, сметной, устанавливается заказчиком);

- проектная (рассчитанная на основе наиболее прогрессивных техникоэкономических показателей);

- нормативная (по установленным нормам, действующим нормам);

- фактическая (действительная);

- условно-фактическая (расчетная, она определяется отношением нормативной к среднему коэффициенту выполнения норм (исчисляется в условных чел.часах).

По функциональному признаку и кругу учитываемых затрат:

- технологическая трудоемкость (основные рабочие);

- трудоемкость обслуживания (затраты вспомогательных рабочих); 


\section{РАЗВИТИЕ НАУКИ В ЭПОХУ ЦИФРОВИЗАЦИИ: ПРОБЛЕМЫ, ТЕНДЕНЦИИ, ПРОГНОЗЫ}

- производственная трудоемкость (основные плюс вспомогательные);

- трудоемкость управления (трудоемкость АУР, кроме рабочих);

- полная трудоемкость (все затраты труда рабочих и АУР) [4, с. 114]

Прежде чем приступить к расчету численности и прогнозированию расходов на персонал необходимо провести оценку состояния нормирования труда на предприятии. Для построения математических моделей необходимо знать уровень качества действующих норм на предприятии. Это будет первым этапом работы над установлением статистического метода нормирования.

Анализ проводится в нескольких направлениях, в нашем исследовании в пяти.

1. Анализ охвата нормированием труда рабочих мест.

2. Анализ уровня выполнения норм или заданий.

3. Провести анализ производительности труда по цехам, участкам, рабочим местам.

4. Установить причины невыполнения плановых заданий или наличие браков. Как правило, отклонения бывают по причинам:

- не соответствие квалификации работников сложности выполняемых работ;

- не соответствие оборудования (новое, устаревшее) действующим типовым или другим нормативам;

- влияние факторов, связанных с установлением размера заработной платы (искусственное завышение заработной платы отдельным исполнителям, занижение зарплаты при отсутствии средств на оплату);

- неточность учета выполненных работ по объему и времени (скрытые сверхурочные работы, скрытые объемы работ).

Каждая причина должна быть подробно изучена и проанализирована.

5. Установить факторы, влияющие на продолжительность оперативного времени, которые будут использоваться при разработке новой нормы времени.

Второй этап работы над установлением статистического метода нормирования предполагает сбор данных, сбор информации. Источники информации могут быть разного уровня от федеральных законов и отраслевых нормативов до локальных нормативных документов самого предприятия. На уровне отдельного предприятия или компании к источникам информации относятся: техническая документация, нормы расхода материалов, проектносметные документы, калькуляции стоимости к договорам, паспорта рабочих 


\section{РАЗВИТИЕ НАУКИ В ЭПОХУ ЦИФРОВИЗАЦИИ: ПРОБЛЕМЫ, ТЕНДЕНЦИИ, ПРОГНОЗЫ}

мест. В первых информационных рядах используются сведения бухгалтерского учета, управленческого учета, оперативная и финансовая отчетность, пояснительные записки к ним, бизнес-планы, акты проверок и ревизий и т.д.

- планово-нормативные источники (данные смет, нормативносправочные материалы, проектно-сметные документации, технические паспорта, нормы расходом материалов, электроэнергии);

- сведения бухгалтерского учета, статистической, оперативной и финансовой отчетности и пояснительных записках к ним.

Третий этап - проверка достоверности собранных данных и установление степени точности.

Заметим, что на уровне предприятия отчетность является работой отдельной группы персонала, при этом результаты и трудозатраты этой работы часто упускаются из виду по причине отсутствия методик, инструкций или понимания в использовании данной информации. Огромное количество отчетов часто носит характер - «что бы было» или «так было всегда». В нашей действительности некоторые отчеты составляются субъективно по просьбе отдельного руководителя. В любом случае необходимо учитывать достоверность отчетных данных. Иногда мы составляем отчеты в угоду комиссии или положению дел. По прошествии времени или при смене персонала, выполняющие эти работы факт может забыться или скрывается.

Например, лишены премии часть персонала по нарушениям, в отчете расходы по заработной плате показаны по факту (то есть в урезанном виде). Другой случай, работник выполнял задания в условиях совместительства или совмещения, как учитывать объем и трудозатраты в том и другом случае понятно, но в последующих периодах изменение общих трудозатрат надо проанализировать не упуская этот фактор, ведь он может влиять как положительно, так и отрицательно на результаты. Таким образом статистические данные нужно не только собрать, но и проверить на соответствие достоверности и установить степени точности каждого показателя.

Для сохранения принципа комплексности планирования, статистические данные, используемые при расчете численности, необходимо разместить в таблицы. Таблицы это распространенная форма изложения материала, которая позволяет правильно хранить и легко ориентироваться в огромном объеме информации. Четвертый этап - составление таблиц для хранения и 


\section{РАЗВИТИЕ НАУКИ В ЭПОХУ ЦИФРОВИЗАЦИИ: ПРОБЛЕМЫ, ТЕНДЕНЦИИ, ПРОГНОЗЫ}

использования статистических данных. На этом этапе важно осознанно подходить к дифференциации любой информации. Главным критерием такого разделения должен быть ответ на вопрос: «Как это можно использовать при расчете численности?» На практике встречаются таблицы с данными, которые не используются только по причине их некорректности.

А время на составление таких данных является трудозатратами на управление и оплачивается из фонда оплаты труда, то есть ложится на себестоимость.

Кроме того, таблицы должны быть по максимуму простыми для удобства поиска и использования информации. Параллельно к таблицам необходимо написать методики заполнения таких информационных отчетов. Так как ведение отчетности происходит в разные календарные периоды, документально утвержденные методики позволяют исключить субъективизм исполнителя и обеспечивают соответствие цифровых значений друг другу. А строгое следование методике позволяет сохранить достоверность информации и исключить риски, которые возникаю в случае неверного толкования и использования информации исполнителем или пользователем информации.

Пятый этап - этап анализа и установления взаимозависимостей.

На этом этапе проводится расчет коэффициентов устойчивости по числовым рядам. Например, отношение расчетная численности и технологической по участку с учетом колебаний объемов работ. Так же возможно рассчитать индексы зависимостей. Например, рассчитывается плановый индекс численности персонала $\left(\mathrm{I}_{\mathrm{q}}\right)$, как отношение планового индекса объема производства $\left(\mathrm{I}_{\mathrm{Q}}\right)$ к плановому индексу производительности труда $\left(\mathrm{I}_{\text {пт }}\right)$ :

$$
\mathrm{I}_{\mathrm{u}}=\frac{\mathrm{I}_{\mathrm{Q}}}{\mathrm{I}_{\Pi \mathrm{T}}}
$$

Этот индекс будет использоваться при расчете плановой численности персонала как произведение базисной численности $\left(\mathrm{I}_{\mathrm{q}}\right)$ на ее плановый индекс $\left(\mathrm{I}_{\text {ч }}\right)[5$, c. 157$]$.

Рассмотрим применение статистического метода расчета численности на примере пассажирского комплекса железных дорог.

В рамках проведения самостоятельного исследования, удобно рассмотреть этот метод прогнозирования норматива численности персонала, так персонал пассажирского комплекса занят на разных видах деятельности: 


\section{РАЗВИТИЕ НАУКИ В ЭПОХУ ЦИФРОВИЗАЦИИ: ПРОБЛЕМЫ, ТЕНДЕНЦИИ, ПРОГНОЗЫ}

- продажа и обработка проездных документов (кассиры билетные, операторы по обработке проездных документов);

ремонт и техническое обслуживание подвижного состава (контингент на ремонте и техническом обслуживании);

обслуживание и сервисные услуги в поездах (проводники пассажирских вагонов).

При построении расчетной таблицы для определения необходимой численности персонала использовались следующая информация и числовые значения:

- выполненные объемы работ (услуг);

- расчетная величина потребной (нормативной) численности персонала в соответствии с утвержденными нормативами(нормами);

- величина технологической численности.

Анализ действующих методов расчета персонала показал, что в структуре готовых данных можно выделить две группы численности по профессиям, величина расчета которых зависит от объемов выполняемых работ (расчетная численность) и численность по профессиям, величина расчета которых не зависит от объема выполняемых работ (технологическая численность). В наших примерах доля технологической численности не одинакова и зависит от вида деятельности: продажи 11,0 \% (пункты продаж малодеятельных станций); техническое обслуживание от 14 до $20 \%$; ремонты 35 \% (вспомогательные работы и работы направленные на выполнение технологических требований обеспечения безопасности движения).

Сезонные колебания объемов (зима, лето) не изменяют сильно коэффициента расчета в целом, но при этом резкое общее падение объема выполняемых работ может повлиять на долю технологической численности, которая будет расти в общей структуре численности.

Динамика различна и зависит от вида деятельности:

- в продажах - это рост доли технологической численности и теоретически полное вытеснение сегмента расчетной численности; устойчивость коэффициента расчета $\mathrm{K}_{\mathrm{K}}=1,05$;

- в ремонте - технологическая численность зависит от величины производственных мощностей депо, рассчитанных на определенную сменность и заметно влияет на расчетную численность. Если расчетная численность снизилась до уровня технологической, это неизменно приведет к снижению 


\section{РАЗВИТИЕ НАУКИ В ЭПОХУ ЦИФРОВИЗАЦИИ: ПРОБЛЕМЫ, ТЕНДЕНЦИИ, ПРОГНОЗЫ}

технологической численности через изменение коэффициента сменности; устойчивость коэффициента расчета $\mathrm{K}_{\mathrm{r}}=1,15$;

- у поездных работников - это удержание коэффициент обслуживания на минимальном уровне - в каждом вагоне проводник; устойчивость коэффициента расчета $\mathrm{Kp}=1,09$.

В табл. 1. представлен пример матрицы исходной информации для расчета нормативной численности билетных кассиров.

Таблица 1

Расчет нормативной численности билетный кассиров

\begin{tabular}{|c|c|c|c|c|c|}
\hline Период & $\begin{array}{c}\text { Количество } \\
\text { Оформленных } \\
\text { документов } \\
\text { (приведенных единиц) }\end{array}$ & $\begin{array}{c}\text { Расчетная } \\
\text { численность, } \\
\text { Чел. }\end{array}$ & $\begin{array}{c}\text { В том числе } \\
\text { технологическая, } \\
\text { Чел. }\end{array}$ & $\begin{array}{c}\text { Доля } \\
\text { технологической } \\
\text { Численности, \% }\end{array}$ & $\begin{array}{c}\text { Коэффициент } \\
\text { Расчета,кк }\end{array}$ \\
\hline 1 & $\mathrm{~b}^{1}$ & $\mathrm{H}^{1}$ & $\mathrm{n}^{1}$ & $\mathrm{n}^{1} / \mathrm{H}^{1}$ & $\mathrm{H}^{1} / \mathrm{b}^{1}$ \\
\hline 2 & $\mathrm{~b}^{2}$ & $\mathrm{H}^{2}$ & $\mathrm{n}^{2}$ & $\mathrm{n}^{2} / \mathrm{H}^{2}$ & $\mathrm{H}^{2} / \mathrm{b}^{2}$ \\
\hline 3 & $\mathrm{~b}^{3}$ & $\mathrm{H}^{2}$ & $\mathrm{n}^{2}$ & $\mathrm{n}^{3} / \mathrm{H}^{3}$ & $\mathrm{H}^{3} / \mathrm{b}^{3}$ \\
\hline
\end{tabular}

В табл. 2 представлен пример матрицы исходной информации для расчета нормативной численности работников, занятых на ремонте подвижного состава.

Таблица 2

Матрица для расчета нормативной численности работников, занятых на ремонте подвижного состава

\begin{tabular}{|c|c|c|c|c|c|}
\hline Период & $\begin{array}{c}\text { Объемы ремонта } \\
\text { (приведенных } \\
\text { единиц) }\end{array}$ & $\begin{array}{c}\text { Расчетная } \\
\text { численность, } \\
\text { Чел. }\end{array}$ & $\begin{array}{c}\text { В том числе } \\
\text { технологическая, } \\
\text { Чел. }\end{array}$ & $\begin{array}{c}\text { Доля } \\
\text { технологической } \\
\text { Численности, \% }\end{array}$ & $\begin{array}{c}\text { Коэффициент } \\
\text { Расчета, } \mathrm{\kappa}_{\mathrm{r}}\end{array}$ \\
\hline 1 & $\mathrm{~b}^{1}$ & $\mathrm{H}^{1}$ & $\mathrm{n}^{1}$ & $\mathrm{n}^{1} / \mathrm{H}^{1}$ & $\mathrm{H}^{1} / \mathrm{b}^{1}$ \\
\hline 2 & $\mathrm{~b}^{2}$ & $\mathrm{H}^{2}$ & $\mathrm{n}^{2}$ & $\mathrm{n}^{2} / \mathrm{H}^{2}$ & $\mathrm{H}^{2} / \mathrm{b}^{2}$ \\
\hline 3 & $\mathrm{~b}^{3}$ & $\mathrm{H}^{2}$ & $\mathrm{n}^{2}$ & $\mathrm{n}^{3} / \mathrm{H}^{3}$ & $\mathrm{H}^{3} / \mathrm{b}^{3}$ \\
\hline
\end{tabular}

В табл. 3 представлен пример матрицы исходной информации для расчета нормативной численности работников поездных бригад. 
Таблица 3

\section{Матрица для расчета нормативной численности} работников поездных бригад

\begin{tabular}{|c|c|c|c|c|c|}
\hline Период & $\begin{array}{c}\text { Вагонооборот, } \\
\text { тыс.ваг.км }\end{array}$ & $\begin{array}{c}\text { Расчетная } \\
\text { численность, } \\
\text { Чел. }\end{array}$ & $\begin{array}{c}\text { В том числе } \\
\text { технологическая, } \\
\text { Чел. }\end{array}$ & $\begin{array}{c}\text { Доля } \\
\text { технологической } \\
\text { Численности, \% }\end{array}$ & $\begin{array}{c}\text { Коэффициент } \\
\text { Расчета,кр }\end{array}$ \\
\hline 1 & $\mathrm{~b}^{1}$ & $\mathrm{H}^{1}$ & $\mathrm{n}^{1}$ & $\mathrm{n}^{1} / \mathrm{H}^{1}$ & $\mathrm{H}^{1} / \mathrm{b}^{1}$ \\
\hline 2 & $\mathrm{~b}^{2}$ & $\mathrm{H}^{2}$ & $\mathrm{n}^{2}$ & $\mathrm{n}^{2} / \mathrm{H}^{2}$ & $\mathrm{H}^{2} / \mathrm{b}^{2}$ \\
\hline 3 & $\mathrm{~b}^{3}$ & $\mathrm{H}^{2}$ & $\mathrm{n}^{2}$ & $\mathrm{n}^{3} / \mathrm{H}^{3}$ & $\mathrm{H}^{3} / \mathrm{b}^{3}$ \\
\hline
\end{tabular}

Такой подход к расчету численности имеет прикладной характер, позволяющий обосновывать ряд управленческих решений. По сути, позволяет моделировать результаты при рассмотрении заданных параметров матрицы в перспективе.

Недостатки метода существуют, как и в любой другой методике расчетов:

- величина возможных погрешностей и учет количества факторов, влияющих на точность результата, требуют тщательной проработки;

- важным условием применения такого метода является то, что его рекомендуется применять для расчета численности персонала, только при наличии хорошо поставленного нормирования трудовых процессов.

Положительные стороны предложенного метода:

1. Организация получает инструмент, позволяющий моделировать управленческие решения в динамике, в том числе и уровень производительности труда;

2. Сокращает время на промежуточные расчеты, а также устраняет необходимость проводить дополнительные наблюдения и исследования.

3. Напрямую привязывает расчет к объемам выполняемых работ.

4. Обосновывает условно постоянную численность персонала.

5. Обосновывает расходы на содержание персонала.

6. Возможность использования при управлении затратами как на краткосрочные, так и долгосрочные периоды.

7. Снижает бизнес риски в части расходов на персонал.

8. Доступность и простота в применении.

9. Возможность использования при многофакторном анализе расходов.

10. Позволяет работать с учетом требований ТК РФ, локальных. 


\section{РАЗВИТИЕ НАУКИ В ЭПОХУ ЦИФРОВИЗАЦИИ:

\section{Список литературы}

1. Т.Ю.Зудбинова Бизнес-планирование. Лучший способ предотвратить ошибки./Т.Ю.ЗудбтноваБ-Ростовн/Д; Феникс, 2014-237. - С. 163.

2. Организация, нормирование и оплата труда на железнодорожном транспорте: Учебник для вузов / Ю.Д.Петров, М.В. Белкин, В.П. Катаев и др.; Под ред Ю.Д. Петрова Б М.В. Беокина.-М: Транспор, 2000. - С. 246.

3. Организация, нормирование и оплата труда на железнодорожном транспорте: Учебник для вузов / Ю.Д. Петров, М.В. Белкин, В.П. Катаев и др.; Под ред Ю.Д. Петрова Б М.В. Беокина.- М: Транспор, 2000. - С. 144.

4. Экономика труда: учеб.пособие / В.А. Вайсбурд - М; Издательство «Омега», 2011. - С. 109.

5. Экономика труда: учеб.пособие / В.А. Вайсбурд - М; Издательство «Омега», 2011. - С. 157.

(C) Г.Г. Кирьянова, 202 


\author{
ГЛАВА VII.
}

\title{
УДК 65.011.56
}

\section{ЦИФРОВИЗАЦИЯ ПРЕДПРИЯТИЙ ОБОРОННО-ПРОМЫШЛЕННОГО КОМПЛЕКСА}

\section{Батов Андрей Александрович}

к.э.н., доцент

\author{
Бушмелева Галина Владимировна \\ к.э.Н., доцент \\ ФГБОУ ВО “ИжГТУ имени М.Т.Калашникова”
}

\begin{abstract}
Аннотация: Актуальность исследования обусловлена необходимостью адаптации к быстро изменяющимся условиям предприятий обороннопромышленного комплекса в конкурентной среде. Цель: адаптация предприятий оборонно-промышленного комплекса к условиям конкурентной среды на основе цифровизации. Объект: цифровая информационная инфраструктура предприятий оборонно-промышленного комплекса. Методология проведения работы: в качестве базовой методологии создания цифровой информационной инфраструктуры предприятий обороннопромышленного комплекса для научных исследований выбраны аспекты процессный и ресурсно-факторный адаптивного управления промышленными предприятиями в конкурентной среде. Цифровая информационная инфраструктура предприятий оборонно-промышленного комплекса представлена в виде модели обеспечения управленческих решений. В рамках аспекта ресурсно-факторного адаптивного управления под ресурсами промышленного предприятия (производство, маркетинг, финансы, кадры и др.) понимается конкурентный потенциал управления, зависящий от конкурентного влияния факторов внутренней и внешней среды. Актуальность адаптации предприятий оборонно-промышленного комплекса к конкурентной рыночной среде требует постоянного мониторинга существенных атрибутов (требование заказчика, себестоимость и цены). В рамках предлагаемой методологии
\end{abstract}




\section{РАЗВИТИЕ НАУКИ В ЭПОХУ ЦИФРОВИЗАЦИИ: ПРОБЛЕМЫ, ТЕНДЕНЦИИ, ПРОГНОЗЫ}

цифровизации предприятий оборонно-промышленного комплекса, предлагается в основе цифровой информационной инфраструктуры предприятий оборонно-промышленного комплекса создавать единое информационное пространство структурированное по различным атрибутам, в том числе по ресурсам, факторам, и др. Механизм реализации ресурснофакторного адаптивного управления сводится к измерению состояния промышленного предприятия на основе индикаторов атрибутов, технологизации процесса принятия управленческого решения. Результаты: рассмотрены современные проблемы предприятий оборонно-промышленного комплекса, сформирована задача внедрения новых технологий в зависимости от конкурентного влияния внешней и внутренней среды на ресурсы для обеспечения обоснованности управленческих решений. Аргументировано решение задачи и предложена модель обеспечения управленческих решений как конкурентоспособная информационная инфраструктура предприятий. Новизна инфраструктуры в том, что учитывается зависимость влияния факторов внутренней и внешней среды на ресурсы и др. атрибуты, оказывающие существенное влияние на результат деятельности предприятия. Научная значимость: предложена модель обеспечения управленческих решений на основе структурированной модели единого информационного пространства. Практическая значимость результатов: при обосновании управленческих решений учет и анализ индикаторов состояния влияют на повышение эффективной деятельности предприятия. Полученные результаты целесообразно применять на промышленных предприятиях, a также в организациях любых видов деятельности для мобильности, снижения себестоимости, взаимосвязи с клиентом.

Ключевые слова: цифровизация промышленного предприятия оборонно-промышленного комплекса; модель обеспечения управленческих решений (МОУР); единое информационное пространство промышленного предприятия; мониторинг промышленного предприятия, моделирование решения; имитационная модель; Интеллектуальное обеспечение принятия решения. 


\title{
DIGITALIZATION OF ENTERPRISES OF THE MILITARY-INDUSTRIAL COMPLEX
}

\section{Batov Andrey A. Bushmeleva Galina Vladimirovna}

\begin{abstract}
The relevance of the study is due to the need to adapt to the rapidly changing conditions of the enterprises of the military-industrial complex in a competitive environment. Objective: to adapt the enterprises of the military-industrial complex to the conditions of the competitive environment on the basis of digitalization. Object: digital information infrastructure of enterprises of the militaryindustrial complex. Methodology of the work: as a basic methodology for creating a digital information infrastructure of enterprises of the military-industrial complex for scientific research, the aspects of process and resource-factor adaptive management of industrial enterprises in a competitive environment are selected. The digital information infrastructure of the enterprises of the military-industrial complex is presented in the form of a model for providing management solutions. Within the framework of the aspect of resource-factor adaptive management, the resources of an industrial enterprise (production, marketing, finance, personnel, etc.) are understood as the competitive potential of management, depending on the competitive influence of factors of the internal and external environment. The relevance of the adaptation of enterprises of the military-industrial complex to a competitive market environment requires constant monitoring of essential attributes (customer requirements, cost and prices). Within the framework of the proposed methodology of digitalization of enterprises of the military-industrial complex, it is proposed to create a single information space structured according to various attributes, including resources, factors, etc., based on the digital information infrastructure of enterprises of the military-industrial complex. The mechanism for implementing resource-factor adaptive management is reduced to measuring the state of an industrial enterprise based on attribute indicators, and technologizing the process of making a management decision. Results: modern problems of enterprises of the militaryindustrial complex are considered, the task of introducing new technologies is formed, depending on the competitive influence of the external and internal environment on resources to ensure the validity of management decisions. The solution of the problem is reasoned and a model of providing management solutions
\end{abstract}




\section{РАЗВИТИЕ НАУКИ В ЭПОХУ ЦИФРОВИЗАЦИИ:

as a competitive information infrastructure of enterprises is proposed. The novelty of the infrastructure is that it takes into account the dependence of the influence of internal and external factors on resources, etc. attributes that have a significant impact on the company's performance. Scientific significance: a model for providing management decisions based on a structured model of a single information space is proposed. Practical significance of the results: when justifying management decisions, accounting and analysis of state indicators affect the improvement of the effective activity of the enterprise. The obtained results should be used in industrial enterprises, as well as in organizations of all types of activities for mobility, cost reduction, and customer relationship.

Key words: digitalization of the industrial enterprise of the military-industrial complex; management decision support model (MOUM); unified information space of the industrial enterprise; monitoring of the industrial enterprise, decision modeling; simulation model; Intelligent decision support.

\section{Введение}

XXI век - век информации в глобальной среде. Появилась огромная потребность у пользователей информации в короткие сроки адаптироваться на изменения влияния факторов внешней и внутренней среды. Цифровая экономика стремительно развивается в глобальном мире. Россия также не остается в стороне от этого процесса. Доля цифровой экономики в ВВП развитых стран составляет чуть больше 5\% [1]: в Китае ее объем - 6,9\%, в США и Индии- 5,4\% . Объем экономики Рунета по итогам 2019 г. достигнет 4,7 трлн руб., что на 20\% превышает показатель 2018 г.[2]

В последнее время у предприятий оборонно-промышленного комплекса России возникли проблемы: глобализация привела к запретам на продажу конкурентоспособной гражданской продукции за рубеж; Диверсификация оборонно-промышленного комплекса связана и с изменением соотношения долей гражданской продукции и гособоронзаказа; Рыночные отношения в оборонно-промышленного комплекса не разработали новых механизмов ценообразования; Несовершенство системы принятия решений о направлениях размещения, управления и использования ресурсов, в т.ч. маркетинг и логистика [4]; Недостаток в системах кибербезопасности; Низкая производительность труда и эффективность процессов производства. 


\section{РАЗВИТИЕ НАУКИ В ЭПОХУ ЦИФРОВИЗАЦИИ: ПРОБЛЕМЫ, ТЕНДЕНЦИИ, ПРОГНОЗЫ}

Все эти проблемы необходимо решать: формализовывать и переводить в цифровой вид; реструктурировать процесс управления; в производстве использовать высокотехнологичные процессы. Таким образом, предприятия оборонно-промышленного комплекса в нынешнем состоянии практически неконкурентоспособны на глобальном уровне и для решения необходимы наукоемкие производства, опирающиеся на цифровые технологии.[3]

Цифровизация предприятия оборонно-промышленного комплекса процесс перехода на новую информационную технологию, представленную в виде единой синергетической корпоративной информационной системы, преобразующей всю информацию, необходимую для принятия обоснованных управленческих решений в цифровую форму, реализуемая в модели обеспечения управленческих решений (МОУР) [5]. МОУР является инструментарием менеджера, обеспечивающим принятие и реализацию управленческих решений с учетом адаптации предприятий обороннопромышленного комплекса к условиям конкурентной среды. Цифровизация может разрабатываться и внедряться по единой программе трансформации промышленного предприятия, сориентированная на приоритетные направления: смены корпоративной модели управления предприятием, внедрения высокотехнологических производств и отдельных участков; внедрение инновационных информационных технологий в отдельные функциональные участки; организации системы информационной безопасности.

\section{Методология}

В качестве базовой методологии создания цифровой информационной инфраструктуры предприятий оборонно-промышленного комплексадля научных исследований предложены аспекты процессный и ресурснофакторный адаптивного управления промышленными предприятиями в конкурентной среде. Под ресурсами промышленного предприятия (производство, маркетинг, финансы, кадры, инновации, инвестиции, качество, логистика) понимается конкурентный потенциал управления, который зависит от конкурентного влияния факторов внутренней и внешней среды [6]. Адаптация предприятий оборонно-промышленного комплекса к конкурентной рыночной среде возможно только при постоянном мониторинге конкурентного потенциала на основе совокупности индикаторов с целью обоснования управленческих решений. 


\section{РАЗВИТИЕ НАУКИ В ЭПОХУ ЦИФРОВИЗАЦИИ: ПРОБЛЕМЫ, ТЕНДЕНЦИИ, ПРОГНОЗЫ}

В рамках концепции цифровизации предприятий обороннопромышленного комплекса, предлагается ядро цифровой информационной инфраструктуры предприятий оборонно-промышленного комплекса в виде единого информационного пространства, структурированного по различным атрибутам, в том числе по ресурсам, факторам, требованиям заказчика, себестоимости и ценам.

Модель обеспечения управленческих решений (МОУР) - это интегрированная система теоретических, программных, технических инструментариев, автоматически формирующих отчетные формы, необходимые для экономического обоснования принятия управленческих решений, а также для их реализации и контроля.

Цель МОУР - обеспечение принятия и выработки решений, а также их реализации и контроля.

Задачи МОУР: сбор информационных потоков; структурирование информации; организация единого информационного пространства на основе разработки хранилища данных (ХД); подготовка отчета для решения задач мониторинга, анализа и вариантного моделирования решения; обеспечение исполнения решения.

Функциональное назначение МОУР - формирование у пользователя информационного образа проблемы, соответствующей действительности.

Структура МОУР - система, состоящая из 4 взаимосвязанных блоков, построенная по процедуре принятия решения (рис.1).

1блок «Поступления данных в систему»: предназначен для сбора данных, которые поступают в систему от внутренних и внешних информационных источников. 


\section{РАЗВИТИЕ НАУКИ В ЭПОХУ ЦИФРОВИЗАЦИИ: ПРОБЛЕМЫ, ТЕНДЕНЦИИ, ПРОГНОЗЫ}

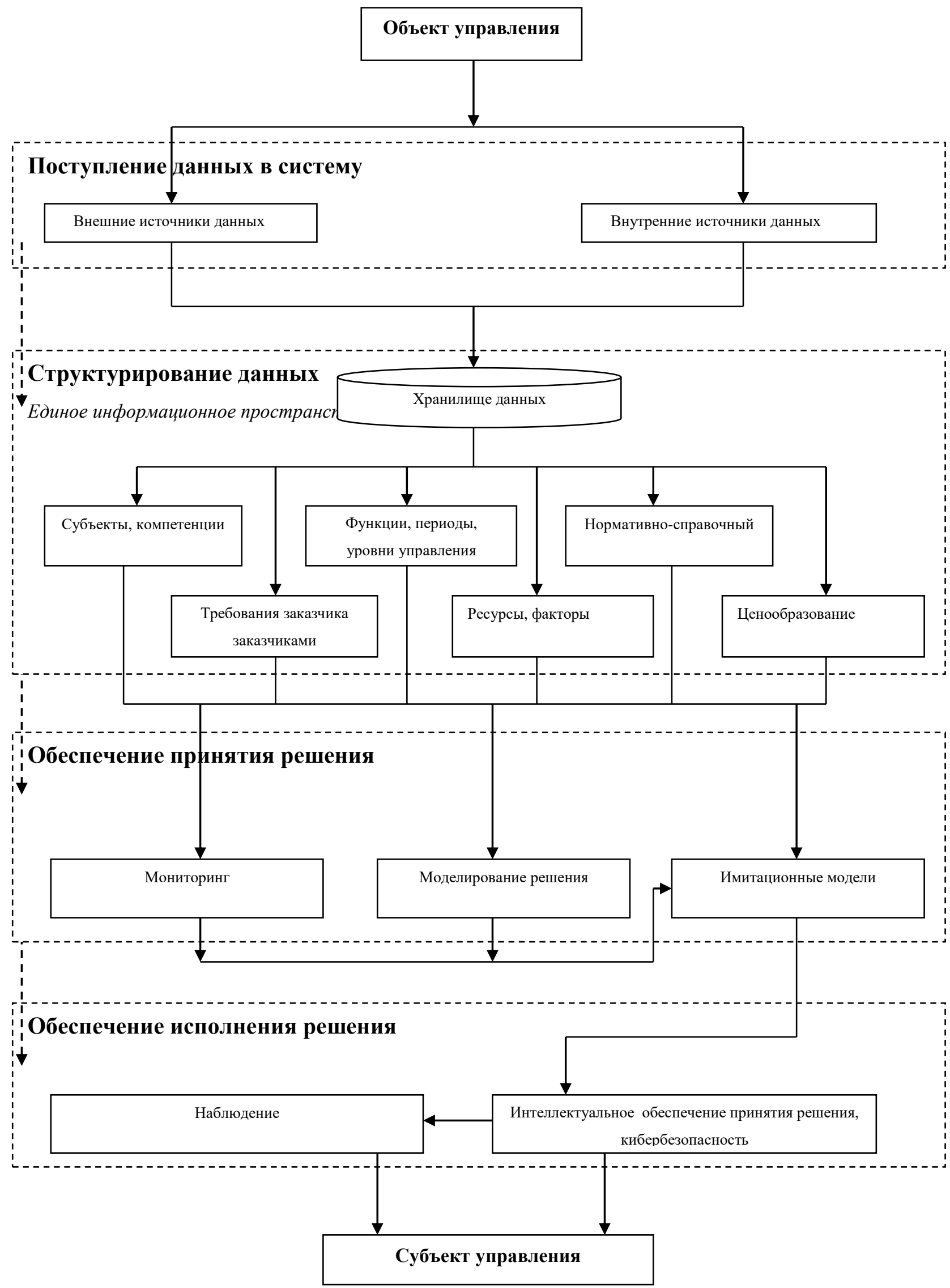




\section{РАЗВИТИЕ НАУКИ В ЭПОХУ ЦИФРОВИЗАЦИИ: ПРОБЛЕМЫ, ТЕНДЕНЦИИ, ПРОГНОЗЫ}

2 блок «Структурирование данных»: состоит из хранилища данных.

Построение хранилища данных является необходимым условием формирования единого информационного пространства. Единое информационное пространство промышленного предприятия информационно-коммуникационное обеспечение модели обеспечения управленческого решения, представлено в виде интеграции входных информационных потоков в хранилища данных, сгруппированных по атрибутам. Атрибут устанавливается по потребностям субъекта управления.

Таблица

\section{Классификация данных по атрибутам}

\begin{tabular}{|l|l|}
\hline Атрибут & Тип классификации \\
\hline Субъект управления & Топ-менеджерам, менеджерам среднего и низшего звена \\
\hline Компетенция & Профессиональные, сформированные \\
\hline Функция управления & $\begin{array}{l}\text { Планирование, прогнозирование,организация, координация, контроль, } \\
\text { мотивация }\end{array}$ \\
\hline Период & Постоянная, периодичная \\
\hline Уровень & $\begin{array}{l}\text { Стратегический, тактический, оперативный; бизнес-единица, или } \\
\text { подразделение, центр финансовой ответственности, предприятие в целом }\end{array}$ \\
\hline Фактор & $\begin{array}{l}\text { Факторы, оказывающие доминирующее влияние: прямого воздействия - } \\
\text { законодательно-правовая база; конкуренты; поставщики; потребители; } \\
\text { косвенного воздействия - экономические факторы; технологические } \\
\text { факторы; социально-культурные и политические факторы [7] }\end{array}$ \\
\hline Нормативно-справочный & Экономические, технические и др. \\
\hline Требование заказчика & Сроки исполнения, технические характеристики \\
\hline Ресурсы & $\begin{array}{l}\text { НИОКР, маркетинг, логистика, финансы, производство, качество, кадры, } \\
\text { инновации, инвестиции }\end{array}$ \\
\hline Ценообразование & Себестоимость, цена \\
\hline
\end{tabular}

Следует особо обратить внимание на атрибуты: «Нормативносправочный», «Требование заказчика», «Ресурсы, факторы», «Ценообразование», которые выделены в хранилище отдельно в связи с особенностями деятельности предприятий оборонно-промышленного комплекса и проблемами, существующими на сегодняшний день.

«Требование заказчика» - это отдельная база данных, систематизированная для анализа и оценки требований заказчика с целью технических возможностей продукции, сроков, стоимости и др. характеристик.

«Ресурсы, факторы»» - это база данных по всем существенным ресурсам и факторам промышленного предприятия, необходимая для принятия решения 


\section{РАЗВИТИЕ НАУКИ В ЭПОХУ ЦИФРОВИЗАЦИИ:

по жизненному циклу продукции от этапа НИОКР до сбыта а также по всем факторам влияния на них. Факторы влияния устанавливаются для наблюдения согласно приоритета. В современном мире эта информация является актуальной, так как предприятия оборонно-промышленного комплекса должны адаптироваться к переходу от гособоронзаказа к продукции ТНП и быть конкурентоспособны.

«Ценообразование» - это база данных, сформированная для моделирования калькулирования себестоимости и установлению рыночной цены.

3 блок «Обеспечение принятия решения»: предназначен для хранения и обработки информации и подготовке по установленному списку индикаторов, необходимых для мониторинга, моделирования решений, построения имитационных моделей.

Блок состоит из трех элементов:

1. Мониторинг.

2. Моделирование решения.

3. Имитационные модели.

Элемент «Мониторинг» - элемент, оперативно обеспечивающий пользователей справедливой информацией, предназначенной для сравнительного анализа индикаторов, что позволяет отслеживать ситуацию и предупреждать негативные ситуации, а также следить за тенденциями развития промышленного предприятия. Наблюдение по ресурсам: маркетинговому, логистических операций, инновациям, качеству, производству, кадрам, дает информацию о ситуации развития. Анализ факторов проводится согласно методики оценки факторов конкурентного влияния на ресурсы предприятий [6]. Внешний мониторинг дает оценку конкурентной среды.

Элемент «Моделирование решения» - элемент прогнозирования путём экстраполирования текущих индикаторов процессов, модель формирует альтернативные варианты, сценарии развития промышленного предприятия. Средствами сценариев система выполняет варианты прогнозных расчетов развития промышленного предприятия. Программные средства системы обеспечивают визуализацию результатов расчетов, полученных при разных сценариях. Такой подход к планированию основывается на разработке комплексной имитационной модели стратегии промышленного предприятия. 


\section{РАЗВИТИЕ НАУКИ В ЭПОХУ ЦИФРОВИЗАЦИИ: ПРОБЛЕМЫ, ТЕНДЕНЦИИ, ПРОГНОЗЫ}

Элемент «Имитационные модели» - комплексная имитационная модель, основанная на логико-алгоритмическом описании, созданная на описании задачи многокритериальной оптимизации атрибутов, использование которых облегчает выработку и оценку альтернатив решения. Сложность идентификации характеристик целесообразно использовать нейронные сети, описывающие нелинейные объекты в терминах «вход-выход» [8]. Используя различные математические модели в имитационном моделировании, можно внедрить оперативно-производственное планирование, нормирование труда и другие современные инструменты менеджера.

4 блок «Обеспечение исполнения решения»: функционирует с помощью двух элементов: интеллектуальное обеспечение и кибербезопасность; наблюдение.

Элемент «Интеллектуальное обеспечение, кибербезопасность» информационно-аналитический элемент, обеспечивает разработку управленческого решения в режиме алгоритма действий информационными данными имитационную модель. Кибербезопасность - этот элемент необходим для защиты от виртуальных ловушек, спамов, рост которых наблюдается в последнее время и для сохранения внутренней инфорамции предприятия, что еще и связано с особой секретностью предприятий оборонно-промышленного комплекса.

Элемент «Наблюдение» - это контроль и оценка результата принятым решением с целью его реализации. Контроль за исполнением решений заключается в представлении отчетов об исполнении поручений с нижних уровней управления на высшие, на основании котрых проводится оценка и разрабатываются корректирующие действия. Вся процедура контроля должна быть регламентирована.

Обеспечение исполнения решения - система, направленная на организацию непрерывного систематического наблюдения за обеспечением реализации исполнения принятых решений на основе совокупности индикаторов.

МОУР - это система обеспечения принятия и исполнения решения, моделирующая решения проблем в опережающем режиме, необходимая менеджерам промышленного предприятия для оперативной и стратегической оценки. 


\section{РАЗВИТИЕ НАУКИ В ЭПОХУ ЦИФРОВИЗАЦИИ:

\section{Результаты}

Современные проблемы предприятий оборонно-промышленного комплекса требуют от менеджмента поиска новых инструментов управления с учетом зависимости конкурентного влияния внешней и внутренней среды на ресурсы. Поэтому предложен инструментарий для обеспечения в виде конкурентоспособной информационной инфраструктуры предприятий - модель обеспечения управленческих решений, которая позволяет визуализировать образ конкурентной среды промышленного предприятия по исследуемым индикаторам (рис.2) [6].

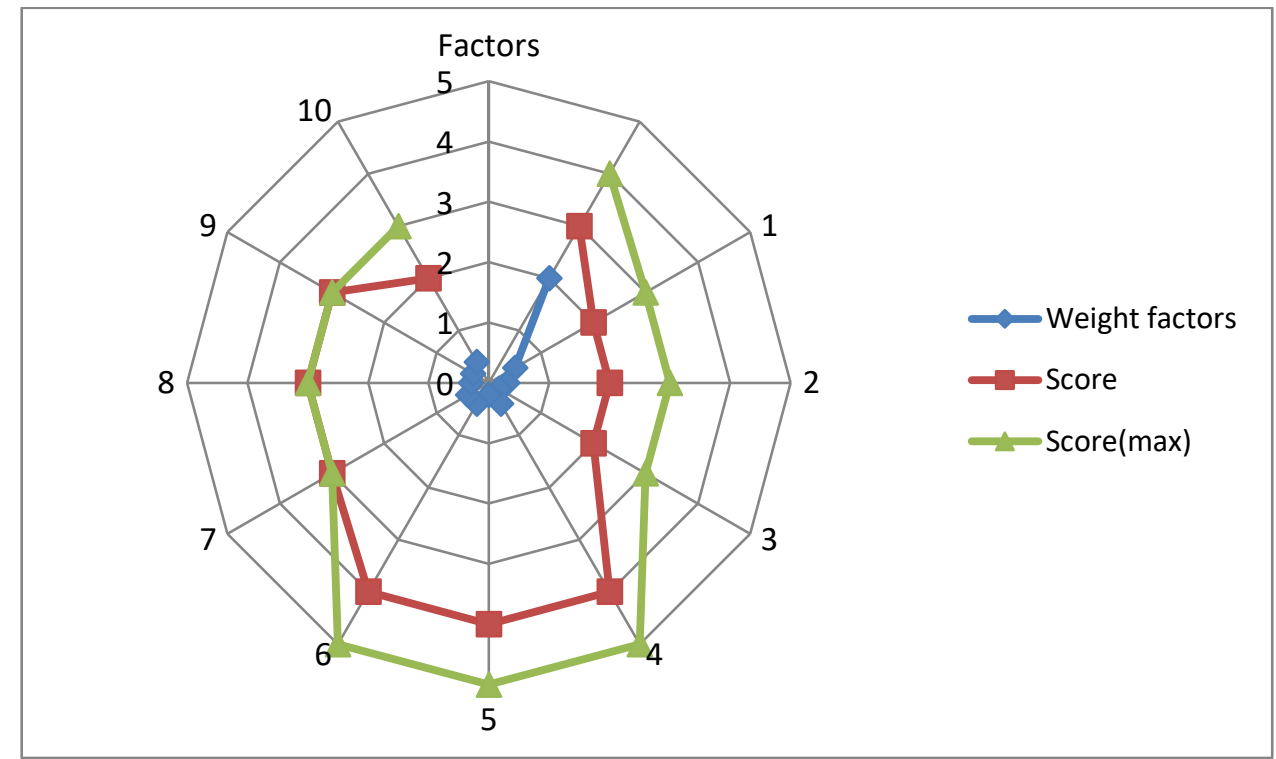

Рис. 2. Образ среды промышленного предприятия

Новизна инфраструктуры в том, что учитывается в обеспечении управленческих решений зависимость влияния факторов внутренней и внешней среды на ресурсы и др. атрибуты, влияющие на результат принятия решения и повышающие их оперативность.

\section{Обсуждение результатов}

Предложенная модель обеспечения управленческих решений на основе структурированной модели единого информационного пространства повысит эффективность деятельности предприятия. МОУР различается от формирования традиционных СППР [9], рекомендующих конечному пользователю не обработанные данные, а предлагает набор возможностей, интерпретацию результатов. Новизна этих положений в том, что обеспечение интеллектуальных решений происходит на основе мониторинга конкурентной и 


\section{РАЗВИТИЕ НАУКИ В ЭПОХУ ЦИФРОВИЗАЦИИ:

внутренней сред с учетом воздействия факторов на ресурсы промышленного предприятия. Полученные результаты целесообразно применять на промышленных предприятиях, a также в организациях любых видов деятельности для мобильности, снижения себестоимости, взаимосвязи с клиентом. Дальнейшее исследование в области цифровизации предприятий оборонно-промышленного комплекса должно быть в области интеграции новой информационной корпоративной системы с уже эксплуатируемыми информационными системами [10].

\section{Выводы}

Актуальные проблемы предприятия необходимо формализовывать в виде совокупности атрибутов, используемых для мониторинга деятельности предприятия и получения профилей для обоснования при принятии решения. В результате формирования инновационного иструментария реализации решения менеджеры получат: план мероприятий по трансформации промышленного предприятия; модель состояния промышленного предприятия; мониторинг изменений - систему регулярного обновления и реализации плана мероприятий; комплексную интеллектуальную корпоративную систему управления промышленным предприятием с подсистемой кибербезопасности. На основании полученных результатов, предполагается, что истоки конкурентоспособности предприятий находятся внутри предприятия в корпоративном управлении, цифровизация позволит повысить: качество управления, ускорить жизненный цикл продукции, улучшить качество производственных процессов, снизить потери, обеспечить рост производительности труда, снизить себестоимость. Однако, постоянные изменения факторов влияния на функционирование предприятий обороннопромышленного комплекса требуют непрерывных исследований.

\section{Список источников}

1. Цифровой экономике пророчат рост// Информационное общество .2017-№3.-С.80

2. Агеев А.И. Битва за будущее: кто первым в мире освоит ноомониторинг и когнитивное программирование субъективной реальности? / А.И. Агеев, Е.Л. Логинов // Экон. стратегии. - 2017. - Т.19, N 2. - С.124-139.

3. Архипова М. Ю., Сиротин В. П. Региональные аспекты развития информационно-коммуникационных и цифровых технологий в РоссииЭкономика региона. — 2019. - Т. 15, вып. 3. - С. 670-683 doi 10.17059/2019-3-4 


\section{РАЗВИТИЕ НАУКИ В ЭПОХУ ЦИФРОВИЗАЦИИ: ПРОБЛЕМЫ, ТЕНДЕНЦИИ, ПРОГНОЗЫ}

4. Sokolova N.G., Titova O.V. Digital marketing as a type: concept, tools and effects // Advances in Economics, Business and Management Research, volume 81 1st International Scientific Conference "Modern Management Trends and the Digital Economy: from Regional Development to Global Economic Growth" (MTDE 2019) / C.509-513. DOI: 10.2991/mtde-19.2019.101, ISBN: 9789462527218.

5. Бушмелева Г.В. Цифровизация промышленного предприятия: актуал изация учета / Г.В. Бушмелева, А.А. Батов // Вопросы управления и экономики: современное состояние актуальных проблем: сб. ст. по материалам XXVIII Международной научно-практической конференции «Вопросы управления и экономики: современное состояние актуальных проблем». - № 10(26)

6. Ресурсно-факторное адаптивное управление промышленными предприятиями в конкурентной среде : диссертация ... доктора экономических наук : 08.00.05 / Бушмелева Галина Владимировна; [Место защиты: ГОУВПО "Удмуртский государственный университет"].- Ижевск, 2012.- 289 с

7. Ресурсно-факторное адаптивное управление промышленными предприятиями в конкурентной среде : автореферат дис. ... доктора экономических наук : 08.00.05 / Бушмелева Галина Владимировна; [Место защиты: Удмурт. гос. ун-т]. - Ижевск, 2012.

8. Августинович В.Г., Кузнецова Т.А., Нугуманов А.Д. Разработка нейронных систем мониторинга и управления эмиссией Известия Томского политехнического университета. Инжиниринг георесурсов. 2019 Т. 330 № $87-17$

9. ...Горемыкина Г.И., Константинова О.В., Мастяева И.Н. Моделирование системы поддержки принятия решений в управлении инвестиционными проектами по предупреждению чрезвычайных ситуаций // Национальные интересы: приоритеты и безопасность. 2017. Т. 13. № 3. C. $514-529$.

10. Специализированная сервисная шина для создания единого информационного пространства компаний нефтегазовой отрасли/ Марков Н.Г., Евсюткин И.В. - С. 326 Программные продукты и системы. - 2019. - Т. 32, № 2 


\title{
Коллектив авторов
}

Андреев Н.А., Ахтариева Р.Ф., Батов А.А., Беляков Б.Л., Бушмелева Г.В., Василенко И.В., Василенко И.В., Везиров Т.Г., Денисов К.М., Дмитриева Т.В., Кирьянова Г.Г., Козаева Г.Р., Лобанова Е.И., Рахманова А.Р., Салимуллина Е.В., Шапирова Р.Р., Шинкевич В.Е.

НАУЧНОЕ ИЗДАНИЕ

\section{ИННОВАЦИОННЫЕ ТЕХНОЛОГИИ В НАУКЕ И ОБРАЗОВАНИИ}

\author{
Монография \\ Подписано в печать 19.04.2021 \\ Формат 60x84 1/16. Усл. печ. л. 6,1. \\ Тираж 500 экз. \\ МЦНП «Новая наука» \\ 185002, г. Петрозаводск \\ ул. С. Ковалевской д.16Б помещ. 35 \\ office@sciencen.org \\ www.sciencen.org
}




\section{НОВАЯ НАУКА \\ Международный центр \\ научного партнерства

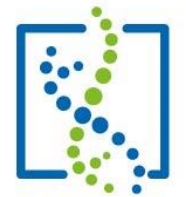 \\ NEW SCIENCE \\ International Center \\ for Scientific Partnership}

МЦНП «НОВАЯ НАУКА» - член Международной ассоциации издателей научной литературы «Publishers International Linking Association»

\section{ПРИГЛАШАЕМ К ПУБЛИКАЦИИ}

1. в сборниках статей Международных

и Всероссийских научно-практических конференций

https://www.sciencen.org/konferencii/grafik-konferencij/

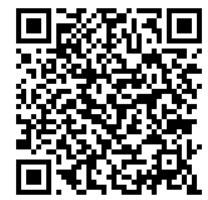

2. в сборниках статей Международных

и Всероссийских научно-исследовательских, профессионально-исследовательских конкурсов

https://www.sciencen.org/novaja-nauka-konkursy/

grafik-konkursov/

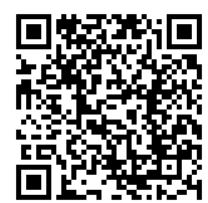

3. в составе коллективных монографий

https://www.sciencen.org/novaja-nauka-monografii/ grafik-monografij/

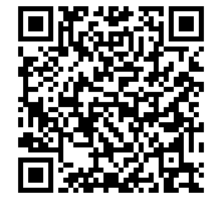

4. авторских изданий

(учебных пособий, учебников, методических рекомендаций, сборников статей, словарей, справочников, брошюр и т.п.) https://www.sciencen.org/avtorskie-izdanija/apply/

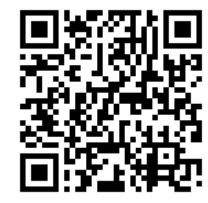

https://sciencen.org/ 